US Army Corps

of Engineers ${ }_{\circledast}$

Engineer Research and

Development Center

Dredging Operations and Environmental Research Program

\title{
Incorporating Color Change Propensity into Dredged Material Management to Increase Beneficial Use Opportunities
}

Jacob F. Berkowitz, Christine M. VanZomeren,

December 2020

Anthony M. Priestas, and Jaybus J. Price

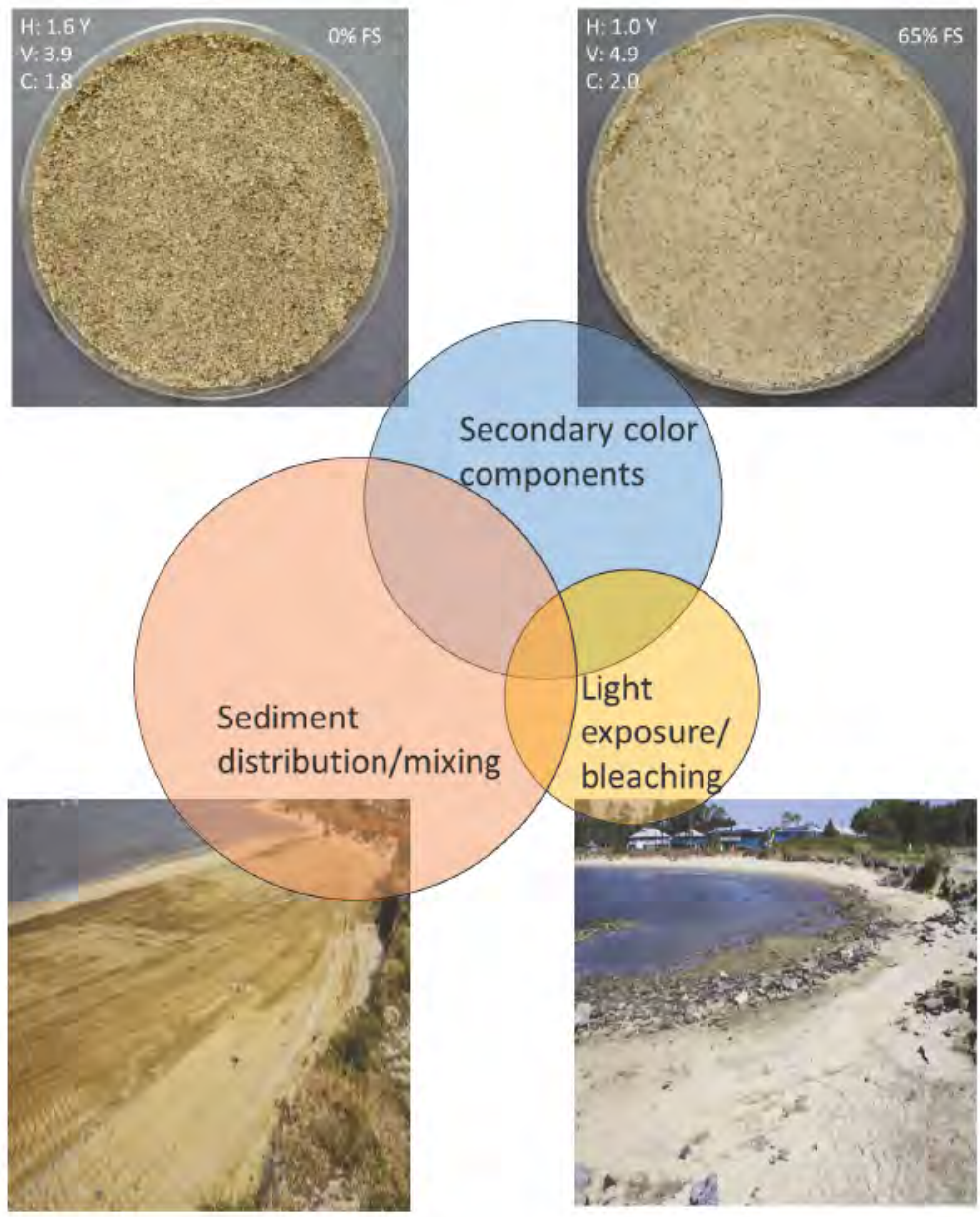


The U.S. Army Engineer Research and Development Center (ERDC) solves the nation's toughest engineering and environmental challenges. ERDC develops innovative solutions in civil and military engineering, geospatial sciences, water resources, and environmental sciences for the Army, the Department of Defense, civilian agencies, and our nation's public good. Find out more at www.erdc.usace.army.mil.

To search for other technical reports published by ERDC, visit the ERDC online library at https://erdclibrary.on.worldcat.org/discovery. 


\section{Incorporating Color Change Propensity into Dredged Material Management to Increase Beneficial Use Opportunities}

Jacob F. Berkowitz, Christine M. VanZomeren, and Jaybus J. Price

Environmental Laboratory

US Army Engineer Research and Development Center 3909 Halls Ferry Road

Vicksburg, MS 39180

Anthony M. Priestas

Coastal and Hydraulics Laboratory

US Army Engineer Research and Development Center 3909 Halls Ferry Road

Vicksburg, MS 39180

Final report

Approved for public release; distribution is unlimited.

Prepared for Dredging Operations Environmental Research 3909 Halls Ferry Road

Vicksburg, MS 39180

Under Funding code 8DBL2F 


\section{Abstract}

Dredged materials provide a number of beneficial use opportunities, including beach nourishment, habitat creation and restoration, and other activities. In situ sediment color is important for determining aesthetic and habitat suitability, for beach nourishment, and for other projects. However, dredged materials must meet locally established color compatibility requirements (for example, material cannot be too dark). Often, potential sediment sources are close to meeting specified color thresholds, and previous observations suggest that sediments lighten over time. In response to these observations, this study quantified sediment color change potential in a dredged material management context. Results indicate that dredged material sediment color responded to changes in secondary color components, sediment mixing, and photolytic bleaching-improving the sediment color for beneficial use application. Findings allowed for development of a conceptual color change capacity framework and supported development of tools for resource managers to incorporate color change dynamic into planning and operations activities. The following report provides a framework for determining the color change capacity of dredged materials using (1) a comprehensive laboratory approach and (2) a semiquantitative index based on source material and placement location conditions. These tools allow practitioners to incorporate dredged-material color change into resource management decisions, thus increasing beneficial use opportunities.

DISCLAIMER: The contents of this report are not to be used for advertising, publication, or promotional purposes. Citation of trade names does not constitute an official endorsement or approval of the use of such commercial products. All product names and trademarks cited are the property of their respective owners. The findings of this report are not to be construed as an official Department of the Army position unless so designated by other authorized documents. 


\section{Contents}

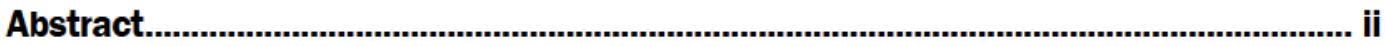

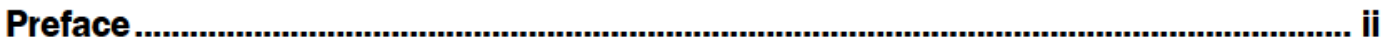

1 Introduction ....................................................................................................1

1.1 Background .......................................................................................

1.1.1 Sediment color considerations in beach nourishment and beneficial use projects ............................................................................................................. 1

1.1.2 Determining sediment color in a beneficial use and sediment management context.

1.1.3 Potential sediment color change dynamics: previous work and mechanisms.

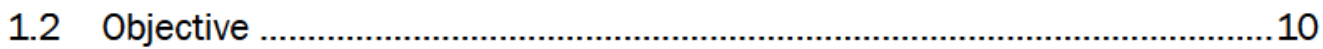

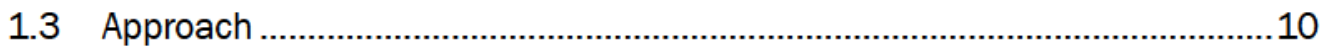

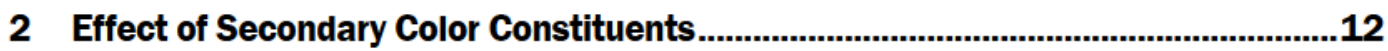

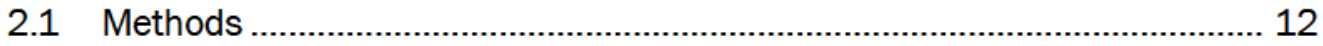

2.1.1 Removal of carbonate ....................................................................................... 14

2.1.2 Removal of organic matter ....................................................................... 14

2.1.3 Removal of iron coatings _........................................................................ 14

2.2 Results and discussion ........................................................................ 15

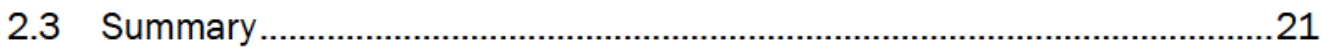

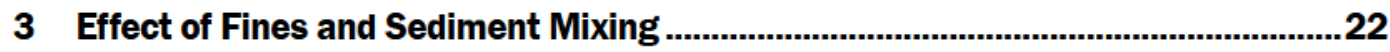

3.1 Coloration according to moisture, composition, and grain size................... 22

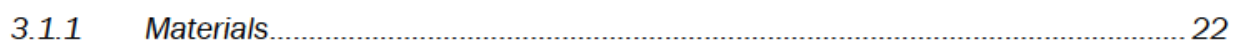

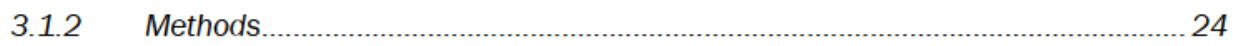

3.1.3 Results and discussion ................................................................................. 25

3.2 Munsell value changes due to mud content and sediment mixing............. 29

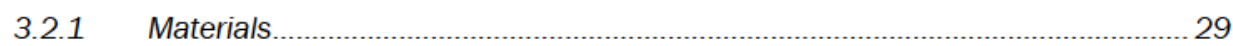

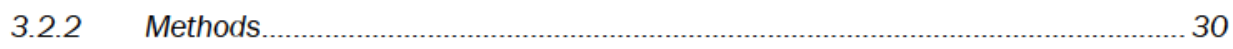

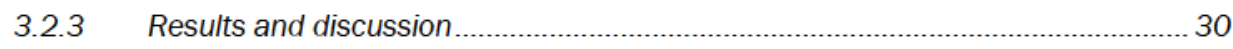

3.2.4 Comparison with field data ............................................................................ 35

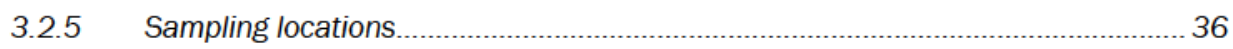

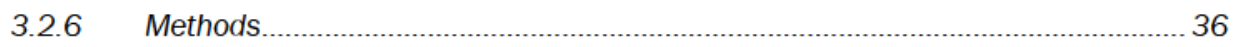

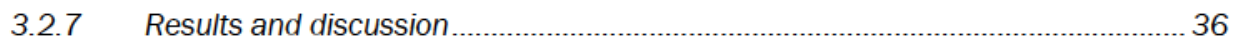

3.2.8 Method to predict Munsell value change from field samples .............................. 39

3.3 Munsell value changes due to mixing and sediment dispersion ................ 42

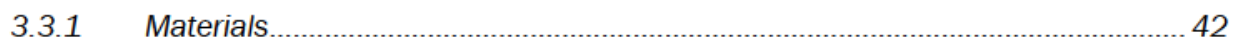

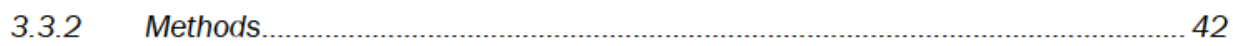

3.3.3 Results and discussion ............................................................................ 42

3.4 Summary and conclusions................................................................ 45

4 Effect of Photolytic Bleaching.....................................................................................4 


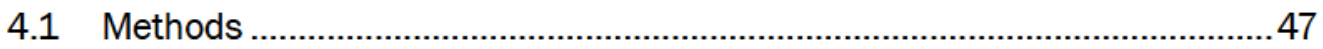

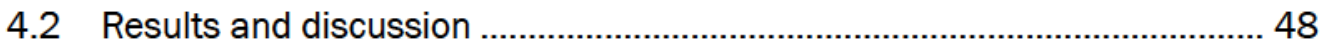

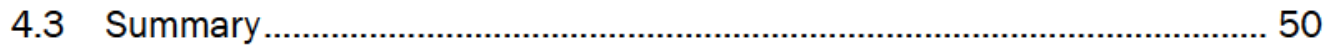

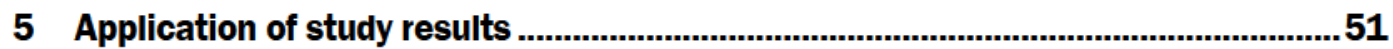

5.1 Quantitative color change potential protocol .......................................... 52

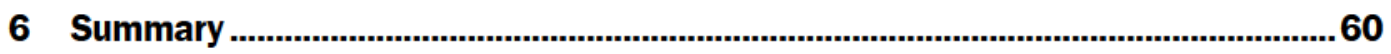

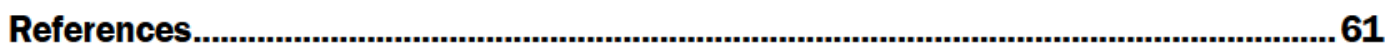

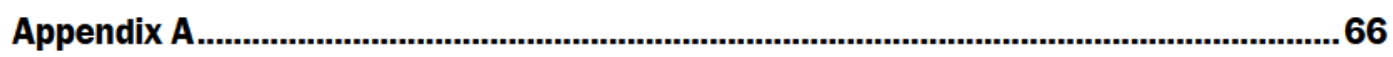




\section{Figures and Tables}

\section{Figures}

Figure 1-1. Example of Munsell color pages typically used to determine sediment color in a field setting (Gretag andMacbeth 2000).

Figure 1-2. Example of dynamic sediment color change following a pilot beach nourishment project near Mobile, Alabama (reproduced from USACE 2013, 71). From left to right, photos represent sediment color immediately following sediment placement, 3.5 weeks post application, and 6.5 weeks postapplication. The sediment color was measured over time, indicating that redder colors transitioned to lighter colors during the monitoring period. However, color changes could not be attributed to any particular mechanism and likely resulted from a combination of mixing with native sand, sediment transport, photochemical bleaching, oxidation, and alteration of iron oxide or other sediment coatings.

Figure 2-1. Munsell value determined in eight sediment samples throughout the sequential laboratory procedure. Where available, measurements with unique letter designations were statistically different at the $\alpha=0.05$ level. The dashed line represents a commonly applied color requirement threshold of $\geq 5.0$. Adapted from Berkowitz et al. $(2018,1152)$.

Figure 2-2. Munsell chroma determined in eight sediment samples throughout the sequential laboratory procedure. Where available, measurements with unique letter designations were statistically different at the $\alpha=0.05$ level. The dashed line represents a commonly applied color requirement threshold of $\leq 2.0$. Adapted from Berkowitz et al. (2018, 1153).

Figure 2-3. Munsell hue determined in eight sediment samples throughout the sequential laboratory procedure. Where available, measurements with unique letter designations were statistically different at the $\alpha=0.05$ level. Adapted from Berkowitz et al. $(2018,1153)$.

Figure 2-4. The sequential removal of secondary color constituents resulted in a visible change in sediment color from in situ condition (left) dominated by a lightening of the sediments due to an increase in Munsell value and a decrease in the Munsell chroma (right). Color changes remain visible to the human eye, with color shifts resulting in more desirable color characteristics for aesthetics and habitat suitability. Adapted from Berkowitz et al. (2018b, 54).

Figure 3-1. Close-up photographs of representative samples from each location used in the X-ray diffraction analysis. Siesta Key, FL (A); Galveston, TX (B); Egmont Key, FL (C); Ventura Harbor, CA (D); Miami, FL (E); Jackson, AL (F); Ocean City, MD (G); Philadelphia, PA (H); and Huntington Harbor, CA (I). Scale bar (red lines) denotes $2 \mathrm{~mm}$ in each image. It is important to note that the sediment color in the images is not necessarily what is perceived by the human eye in sunlight conditions. Images courtesy of Erin Gore, ERDC Geotechnical and Structures Laboratory.

Figure 3-2. Sediment samples (moist state) plotted in the Munsell color space. 28

Figure 3-3. Representative sediment samples in the moist state used in the mixing experiment. $A$ is the pure quartz sand (QS); $B$ is the Vicksburg silt (VS); and $C$ is Mississippi River mud (MS). Samples from VS and MS were screened 
through a $75 \mu \mathrm{m}$ mesh sieve prior to mixing. The initial Munsell value of each sample is indicated in the lower left $(6.1,4.2$, and 2.7 , respectively).

Figure 3-4. Color evolution of pure quartz sand with increasing percent fines derived from two different sources, Vicksburg silt (A) and Mississippi River mud (B).

Figure 3-5. Measured changes in Munsell value for two sediment mixtures, quartz sand with added Vicksburg silt (blue), and quartz sand with added Mississippi River mud (yellow). Dashed lines indicate probable evolution of Munsell value to respective end-member states at $100 \%$ fines content.

Figure 3-6. Observed and modeled changes in Munsell value as a function of the fines fraction by mass. The end-member Munsell value (where $f=1.0$ ) for each mud type is indicated by the dashed lines at Munsell value $=4.2$ and 2.7. The dashed line at Munsell value $=5.0$ indicates the threshold Munsell value commonly used in beach nourishment regulations (most notably FL). The threshold value is reached at $f=0.11$ in the Vicksburg silt case (VS) and $f=0.03$ using Mississippi river mud (MS). Also shown are the $95 \%$ prediction bands of the model fit.

Figure 3-7. Measured Munsell values of dredged sediments taken in the field as a function of percent fines. Galveston samples were obtained from the hopper dredge Terrapin Island inflow and overflow (unpublished data courtesy of Coraggio Maglio, USACE Galveston District). Ship Island samples were obtained aboard the dredge Liberty Island taken at the inflow, hopper, and postplacement beach locations. Although there is much scatter in both datasets, the trends of the relationships are similar to that of the laboratory data.

Figure 3-8. Sensitivity of rate constant to equation (1) while holding parameters $A$ and $C$ constant

Figure 3-9. Sensitivity of equation (1) to parameter $\boldsymbol{A}=(\boldsymbol{V} \mathbf{0}-\boldsymbol{V} \mathbf{1})$ while holding $k$ and $C$ constant.

Figure 3-10. Modeled data from four hypothetical field samples shown as averages with sample variability (the data point at $f=1$ is a single, composited sample obtained from all retained fines).

Figure 3-11. Photograph comparing Ventura Harbor, California, dredge sediment before (left) and after (right) adding $65 \%$ by mass of clean, fine sand. The Munsell value of the $100 \%$ fine sand was $6.1(\mathrm{H}: 1.6 \mathrm{Y}, \mathrm{V}: 3.9, \mathrm{C}: 1.8)$, while that of the dredged sediment was $3.9(\mathrm{H}: 1.0 \mathrm{Y}, \mathrm{V}: 4.9, \mathrm{C}: 2.0)$.

Figure 3-12. Evolution of Munsell value as a function of mixing clean, bright sand with darker, dredged material (Ventura Harbor sediment, Munsell value $=3.8$ ). Here, the VH sediment is essentially being dispersed with proxy native material. The line is based on the inset equation $([y(x)=a x+b]$, where $a=1.63$ and $b=$ 3.80; $\mathrm{R}=0.94$.)

Figure 3-13. Design schematics of typical nourishment templates (after NRC 1995).

Figure 3-14. Pump-out operations during an active beach nourishment project. Photo courtesy of David Nguyen, ERDC Coastal and Hydraulics Laboratory.

Figure 4-1. Representative example of photolytic bleaching results (sample FL2) displaying the observed increase in Munsell value (-+-; left axis) and decrease in Munsell chroma ( $\boldsymbol{A}_{\boldsymbol{B}}$; right axis). Note the majority of color change occurred 
within $~ 30$ days beyond which the rate of color change significantly decreases (lines approximate change in slope).

Figure 5-1. Conceptual model of sediment color change potential for beneficial use applications. The model identified the mechanisms by which sediment change can occur in a dredged material management context. Components are weighted (by area) according to the relative magnitude of observed color changes. Adapted from Berkowitz et al. (2018b)..

Figure 5-2. Quantitative protocol for determining sediment color change potential. Note that the specific instructions for conducting each evaluation are provided in sections 3-5 of this report.

Figure 5-3. Flow chart for determining semiquantitative dredges sediment color change potential of secondary color components.

Figure 5-4. Flow chart for determining semiquantitative dredges sediment color change potential of mixing assessment

Figure 5-5. Flow chart for determining semiquantitative dredges sediment color change potential of bleaching assessment. An example of synthesis of the three data components is also provided to aid in application of the DSCCPI.

Figure A-1. Siesta Key, FL size gradation (A), images in dry and moist state (B) and images by size class (C)

Figure A-2. Galveston, TX size gradation $(A)$, images in dry and moist state $(B)$ and images by size class $(C)$.

Figure A-3. Egmont Key, FL size gradation $(A)$, images in dry and moist state $(B)$

and images by size class (C)

Figure A-4. Ventura Harbor, CA size gradation (A), images in dry and moist state

(B) and images by size class (C).

Figure A-5. Miami, FL size gradation (A), images in dry and moist state $(B)$ and images by size class (C).

Figure A-6. Huntington Harbor, CA size gradation $(A)$, images in dry and moist state $(B)$ and images by size class $(\mathrm{C})$.

Figure A-7. Philadelphia, PA size gradation $(A)$, images in dry and moist state $(B)$ and images by size class (C)

Figure A-8. Jackson, AL size gradation (A), images in dry and moist state $(B)$ and images by size class $(\mathrm{C})$.

Figure A-9. Ocean City, MD size gradation $(A)$, images in dry and moist state $(B)$ and images by size class $(\mathrm{C})$.

\section{Tables}

table 1-1. examples of sediment physical and color specifications required for beach nourishment projects. note, " $x$ " denotes citations that require sediment compatibility but lack a specific numerical value. †varies according to source location. $\mathrm{CaCO}_{3}-$ calcium carbonate. munsell colors represent moist sediment conditions (adapted from berkowitz et al. 2018, 1150).

table 2-1. sediment sample location, mean particle size $(\mu \mathrm{m}), \mathrm{d}_{50}(\mu \mathrm{m})$, and mineral composition as percent weight of quartz (q), carbonates (c) and feldspars (f). note that sediments used in the study represent a variety of geographic 
source locations, grain sizes, and mineral compositions. adapted from berkowitz

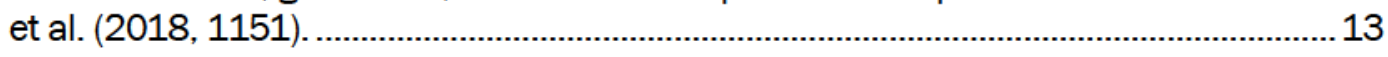

table 3-1. locations and ids of samples used for color analysis.......................................... 22

table 3-2. summarized grain size statistics of representative sediment samples used in the color analysis.

table 3-3. mineral constituents (est. wt\%) of representative samples used in the phase i color analysis.

table 3-4. summary of fitted model parameters and associated confidence limits derived from laboratory experiment. 33

table 3-5. summary of fitted model parameters and $95 \%$ confidence limits derived from field data. 37

table 3-6. hypothetical data to derive rate constant for equation (1). 


\section{Preface}

This study was conducted for the US Army Corps of Engineers Dredging Operation Environmental Research Program (DOER) under the Sediment and Dredging Processes Focus Area leader Dr. Joe Gailani; Dr. Todd Bridges was Program Manager. The work was performed by the Wetlands and Coastal Ecology Branch of the Ecosystem Evaluation and Engineering Division, US Army Engineer Research and Development Center (ERDC), Environmental Laboratory (EL); and Anthony Priestas of the Field Data Collection and Analysis Branch of the Navigation Division, US Army Engineer Research and Development Center, Coastal and Hydraulics Laboratory (CHL). At the time of publication, Ms. Patricia Tolley was Chief of the Wetlands \& Coastal Ecology Branch; Mr. Mark Farr was Chief of the Ecosystem Evaluation and Engineering Division of ERDC-EL. The Deputy Director of EL was Dr. Jack E. Davis and the Director was Dr. Edmond J. Russo Jr.

The authors would like to thank the following individuals for providing sediment samples for analysis: Coraggio Maglio, Jase Ousley, Jennifer Coor, Jeremy Jackson, Travis Fatzinger, Derek Kendrick (all of USACE), Brett Moore of Humiston and Moore, and Ivette Batista of Coastal Systems International. Coraggio Maglio and Jase Ousley helped to develop the study concept and provided comments on a draft version of this report. Cover photos from Anthony Priestas (top) and reproduced from USACE (2013; bottom).

The Commander of ERDC was COL Teresa A. Schlosser and the Director was Dr. David W Pittman.

Portions of this report have been modified and reprinted with permission from Jacob F. Berkowitz, Christine M. VanZomeren, and Anthony M. Priestas. 2018. "Potential Color Change Dynamics of Beneficial Use Sediments." Journal of Coastal Research 34, no. 5 (September): 1149-1156. https://doi.org/10.2112/JCOASTRES-D-17-00161.1. Public domain.

Portions of this report have been modified and reprinted with permission from Anthony M. Preistas, Jacob F. Berkowitz, and Christine M. VanZomeren. 2019. Proceedings of the 9th International Conference: Coastal 
Sediments 2019. https://doi.org/10.1142/9789811204487_0244. Copyright World Scientific Publishing Company. https://www.worldscientific.com/worldscibooks/10.1142/11391. 


\section{Introduction}

The following sections provide context for the role of sediment color change dynamics in dredged material management. Report sections focus on the state of the science regarding sediment color implications for habitat, field measurements of sediment color, previously completed research on sediment color change, and the study approach used.

\subsection{Background}

\subsubsection{Sediment color considerations in beach nourishment and beneficial use projects}

During the past three decades, coastal resource managers increasingly recognized the benefits of using sediment for beach nourishment and other activities (Natural Research Council 1995). Many studies highlight that intentionally placed sediments spatially expand coastal areas, prevent erosion, contribute to dune formation and maintenance, maintain sediment balances, protect infrastructure, and mitigate potential sea level rise effects (Dean 2003; Hanson et al. 2002). As a result, many communities incorporate beach nourishment into regional sediment management and dredged material beneficial use programs. However, concerns persist regarding sediment compatibility between source materials (for example, dredged sediments) and placement locations (Stauble 1991; Gravens et al. 2008).

The defining factors and regulatory limitations associated with sediment compatibility vary widely among placement locations and sometimes include qualitative or quantitative thresholds for sediment particle size and mineralogy (Williams 2005). However, specific requirements for sediment compatibility are often lacking or generalized. As a result, the current study reviewed $>50$ documents from coastal communities throughout the United States to investigate the variability in approaches applied (representative values provided in table 1-1; Berkowitz et al. 2018, 1150). Additionally, several federal, state, and local agencies require that the sediment color meet some criteria before approving sediment placement projects (Florida Department of Environmental Protection 2014, 2015). Inconsistencies between sediment color at source and placement locations may limit their beneficial use in coastal areas (Nordstrom 2005). Although 
evaluating sediment color for compatibility is considered good practice in beach nourishment, guidance documents rarely identify specific acceptable ranges (Pranzini et al. 2010). As a result, compatibility between sediment source and placement areas often relies primarily on grain size characteristics, because limitations associated with sediment color remain poorly defined (Gravens et al. 2008).

Published literature indicates that concerns about recreation (that is, aesthetics) and maintaining habitat suitability drive most sediment color compatibility requirements. Several reports and guidance documents address the importance of aesthetics in sediment compatibility associated with beach nourishment initiatives (California Geological Survey 2005; California Coastal Commission 2010). Sediment color and texture affect the recreational usage and public perceptions of beach nourishment outcomes (Finkl and Walker 2005). For example, Pranzini et al. (2010) indicated the need to maintain light-colored sediments at popular tourist sites in Oahu, Hawaii.

Literature regarding habitat concerns is more readily available, with numerous studies examining sediment color's effect on sediment temperature and habitat suitability. For example, Ackerman et al. (1992) found that beaches nourished with darker materials absorbed more solar radiation than light colored sediments and displayed significantly higher temperatures. Weber et al. (2011) identified consistently $2-3^{\circ} \mathrm{C}^{1}$ higher sediment temperatures in dark sands than lighter colored sands on turtle nesting beaches in Australia. Sediment color and temperature can change sea turtle brood sex ratios, profoundly influencing sea turtle populations (Crain et al. 1995; Nordstrom 2005). Notably, turtle temperature-dependent sex determination occurred in 64 out of 79 turtle species examined in a review in Hulin et al. (2007). Further, Hays et al. (2001) reported sediment color and albedo differences significantly influenced temperatures at both the surface and at green turtle (Chelonia mydas) nesting depths (75 $\mathrm{cm})$. In that study, dark sediments resulted in sediment temperature increases of up to $4 \cdot 2^{\circ} \mathrm{C}$. Healthy turtle nesting temperatures occupy a narrow range $\left(25^{-}-33^{\circ} \mathrm{C}\right)$, outside of which morphological abnormalities and mortality can occur, although sediment-temperature interactions vary by

1. For a full list of the spelled-out forms of the units of measure used in this document, please refer to US Government Publishing Office Style Manual, 31st ed. (Washington, DC: US Government Publishing Office, 2016), 248-52, https://www.govinfo_gov/content/pkg/GPO-STYLEMANUAL-2016/pdf/GPOSTYLEMANUAL-2016.pdf. 
location and species (Fuentes et al. 2009). Several studies identify pivotal break points $\left(29^{\circ} \mathrm{C}\right)$ above which female hatchlings outnumber male hatchlings, potentially disrupting natural sex ratios (Hays 1999, 2001). Milton et al. (1997) stated that while beach nourishment undoubtedly can benefit sea turtle nesting habitat, care must be taken to avoid increasing or decreasing temperatures substantially, especially near the $29.7^{\circ} \mathrm{C}$ pivot point observed in loggerhead sea turtles (Caretta caretta) nesting in the southeastern United States. As a result, Crain et al. (1995) and others recommend project managers consider potential sediment color changes during planning and implementing beach nourishment and other beneficial use projects. 
Table 1-1. Examples of sediment physical and color specifications required for beach nourishment projects. Note, "X" denotes citations that require sediment compatibility but lack a specific numerical value. †Varies according to source location. $\mathrm{CaCO}_{3}{ }^{2-} \mathrm{Calcium}$ carbonate. Munsell colors represent moist sediment conditions (adapted from Berkowitz et al. 2018, 1150).

\begin{tabular}{|c|c|c|c|c|c|c|c|c|c|c|}
\hline Region & $\begin{array}{l}\text { Grain size } \\
(\mathrm{mm})\end{array}$ & $\begin{array}{l}\text { Silt } \\
(\%)\end{array}$ & $\begin{array}{l}\text { Grave } \\
\mathrm{I}(\%)\end{array}$ & $\begin{array}{l}\text { Shell } \\
(\%)\end{array}$ & $\begin{array}{l}\mathrm{CaCO} \\
\mathbf{3}(\%)\end{array}$ & $\begin{array}{l}\text { Sedimen } \\
\text { t color }\end{array}$ & $\begin{array}{l}\text { Munsell } \\
\text { Hue }\end{array}$ & $\begin{array}{l}\text { Munsell } \\
\text { value }\end{array}$ & $\begin{array}{l}\text { Munsell } \\
\text { Chroma }\end{array}$ & Citation \\
\hline United States & $x$ & & & & & $\mathrm{X}$ & & & & (USACE 1995) \\
\hline United States & $x$ & & & & $x$ & & & & & (Stauble 1991) \\
\hline Florida & $0.062-4.76$ & & & & $X$ & & & & & (FLDEP 2010) \\
\hline Broward, FL & $0.35-0.65$ & $<2.0$ & & $<2.0$ & & & & $>7.0$ & $<1.0$ & (FLDEP 2012a) \\
\hline $\begin{array}{l}\text { Miami-Dade, } \\
\text { FL }\end{array}$ & & $<5.0$ & $<5.0$ & & & & & $>6.0$ & $<1.0$ & (FLDEP 2012b) \\
\hline $\begin{array}{l}\text { Miami-Dade, } \\
\text { FL }\end{array}$ & $0.3-0.55$ & $<5.0$ & & $<60$ & & & 2.5YR-5Y & $6-8$ & $\leq 3.0$ & (USACE 2016) \\
\hline Duval, FL & $0.18-0.40$ & $\leq 5.0$ & $\leq 5.0$ & $\leq 0.5$ & $\leq 018$ & & $\begin{array}{l}7.5 Y R- \\
2.5 Y\end{array}$ & $\geq 5.0$ & $\leq 2.0$ & (FLDEP 2015) \\
\hline Charlotte, FL & & $\leq 5.0$ & & $\begin{array}{l}\leq 5.0 \text { or } \\
\leq 10 \dagger\end{array}$ & & & & $\geq 6.0$ & $<1.0$ & (FLDEP 2014) \\
\hline Galveston, TX & $x$ & & & & & $x$ & & & & (Frey et al. 2016) \\
\hline Jefferson, TX & $X$ & & & & $X$ & $x$ & & & & $\begin{array}{l}\text { (பA Engineering } \\
2016 \text { ) }\end{array}$ \\
\hline Mississippi & $x$ & & & & $\mathrm{X}$ & $x$ & & & & (USACE 2016) \\
\hline North Carolina & $x$ & & & & $X$ & & & & & (NCDCM 2013) \\
\hline Virginia & $x$ & & & & & & & & & (USACE 2008) \\
\hline Massachusetts & $x$ & & & & & & & & & (MDEP 2007) \\
\hline California & $x$ & & & & $x$ & $x$ & & & & (CGS 2005) \\
\hline $\begin{array}{l}\text { Newport } \\
\text { Beach, CA }\end{array}$ & $X$ & & & & & & & & & (Johnson 2009) \\
\hline
\end{tabular}

2. For a full list of the spelled-out forms of the chemical elements used in this document, please refer to US Government Publishing Office Style Manual, 31st ed. (Washington, DC: US Government Publishing Office, 2016), 265, https://www.govinfo.gov/content/pkg/GPO-STYLEMANUAL-2016/pdf/GPO-STYLEMANUAL2016.pdf. 


\subsubsection{Determining sediment color in a beneficial use and sediment management context}

Sediment color remains one of the most obvious and commonly reported substrate characteristics (Soil Survey Staff 1951; Post et al. 1993). Measuring sediment color is common in a number of fields, including marine geology, ecology, soil taxonomy, and coastal sciences (Bigham and Ciolkosz 1993). For example, Giosan et al. (2002) used color to determine marine sediment origins and investigate sediment deposition processes. Others linked erosion and sedimentation processes through evaluating diagnostic sediment color characteristics (Martínez-Carreras et al. 2010).

Field color determinations are often made using the Munsell Soil Color system, which applies three parameters (hue (H), value (V), and chroma (C)) to characterize sediment color (Gretag and Macbeth 2000; figure 1-1). Hue is the spectral color a sediment exhibits, represented by a number-letter pair. Letter designations include red $(\mathrm{R})$, yellow $(\mathrm{Y})$, neutral $(\mathrm{N})$, green $(\mathrm{G})$, blue (B), and purple (P). Hues either use one color (R) or a combination of different colors. For example, the designation YR refers to the yellow-red color range. Munsell hue numbers indicate color purity, with 5 representing a pure color ( $5 \mathrm{Y}$ denotes pure yellow). The Munsell value designation represents a sediment's lightness or darkness, and is the most commonly applied measurement in the beach nourishment context (table 2-1). Munsell values typically range from 2 to 8 , with lower values assigned to dark sediment colors and higher values assigned to light or white sediment colors. Munsell chroma represents the saturation or intensity of color, with higher chroma corresponding to brighter, bolder color. 
Figure 1-1. Example of Munsell color pages typically used to determine sediment color in a field setting (Gretag andMacbeth 2000).

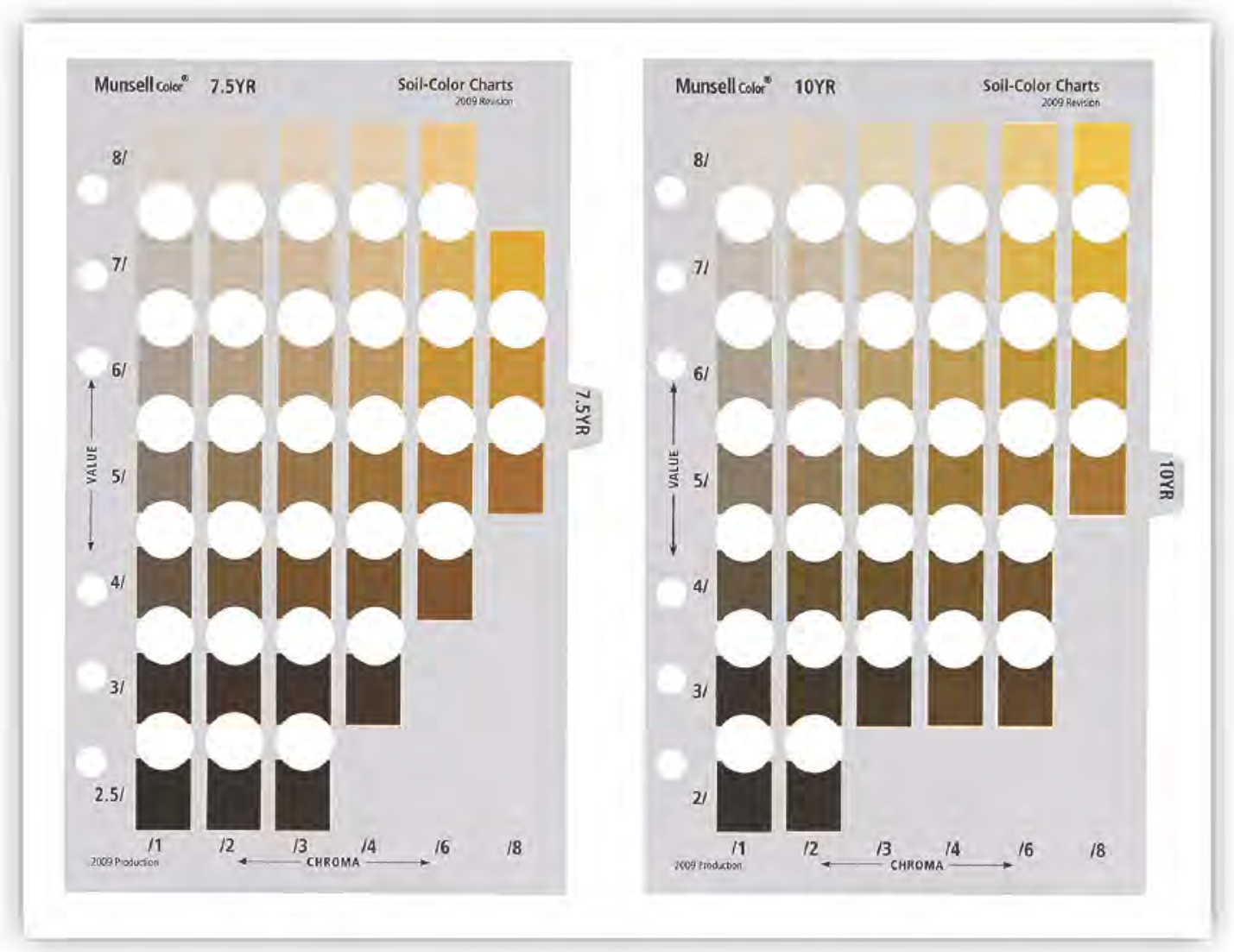

Scientists typically examine moist sediments to determine color descriptions, although dry colors are sometimes reported. Vasilas and Berkowitz (2016) describe sediment color determination and provide guidance on using the Munsell color notation. Although sediment color requirements vary regionally and often project-by-project, beneficial use projects generally require light colored sediments, corresponding to Munsell values of $\geq 5$. 0 (table 2-1). Additionally, some requirements also specify that sediments must have low chroma $(\leq 2)$. Sediment hue is less frequently a requirement in beneficial use projects, but when applied, hues are typically specified in the yellow-red or yellow color ranges. For the purposes of the current report, color thresholds for beneficial use applications will use the Munsell values of $\geq 5$. 0 and chroma $\leq 2$ thresholds applied in numerous case studies and regulatory documents.

Appropriately managing coastal, estuarine, and riverine settings requires accurately determining sediment color, because sediment color is important in beach nourishment and other beneficial use projects. However, 
the repeatable, systematic measurement of sediment color remains challenging, especially under field conditions (Post et al. 1993). Some practitioners suggest that visual sediment color observation represents only a semiquantitative measurement, although several scientific studies demonstrated positive relationships between visual color estimates and spectrographic method determinations (see Kamrunnahar et al. [2004] and Rabenhorst et al. [2015], for example). For example, Shields (1966) reported that 12 experienced practitioners accurately described Munsell values, with minimal variability among test subjects ( 0.5 and 0.2 units), demonstrating that trained professionals can accurately determine sediment color.

Examining sediment color provides a mechanism for evaluating sediment properties and processes in coastal, riverine, or riverine settings (Andrews and Freedman 1996). Giosan et al. (2002) discusses the origin and nature of sediment color, identifying particle size and mineralogy as the primary drivers of chromatic properties. Other factors associated with sediment color include the presence of white carbonates, which can increase sediment lightness (Balsam and Deaton 1991). Organic matter can coat sediment particles, leading to darker sediment characteristics (Mayer 1999) and lower Munsell values (Vasilas and Berkowitz 2016). Iron oxide and oxyhydroxide coatings also contribute to sediment color, with amorphous and crystalline coatings of hematite, goethite, ferrihydrite, and other compounds imparting red and yellow-red hues to the sediment surface contributing to higher Munsell chroma (Schwertmann 1993).

Sediment color results from a combination of constant, primary characteristics (mineralogy) and variable, secondary processes that may potentially change with environmental conditions (Giosan et al. 2002). Secondary processes include carbonate accumulation and removal, organic matter, iron coatings, and changes in pore water chemistry caused by environmental factors. For example, organic coatings can mask the inherent sediment particle color and impart lower Munsell values (Vasilas and Berkowitz 2016). However, organic matter coatings can oxidize and separate, revealing the underlying naked sediment grain color (Canfield 1993; Mayer 1999). Additionally, iron oxide coatings respond to changes in sediment oxidation-reduction potential, leading to dissolution or precipitation of iron compounds and resulting in a rapid sediment color shift (Vepraskas et al. 2016). A sediment's potential color change is related to a combination of these factors as well as mixing with native sediments and photolytic 
bleaching effects (described below). Yet, as described below, few studies have systematically examined the capacity for color shifts under either controlled laboratory conditions or field settings.

\subsubsection{Potential sediment color change dynamics: previous work and mechanisms}

Although several practitioners report sediment color change after beneficial use project placement, the sediment color change process and associated underlying mechanisms remain poorly documented (Pranzini et al. 2010). For example, US Army Corps of Engineers (2013) monitored sediment colors following a beach nourishment application, reporting an average Munsell value increase of $1.43 \pm 0.30$ within 12 months of placement (figure 1-1). Additionally, Munsell hues shifted from predominately yellowred spectra (10YR) to yellower colors $(2.5 \mathrm{Y})$ and showed a small decrease in average Munsell chroma. This changed the deposited sediments from darker, redder colors to lighter, more yellow sediments over time. In line with typical sediment color requirements, lighter and yellower sediments are more desirable for both recreational and habitat compatibility goals. However, the study did not distinguish between potential color change mechanisms, suggesting that the observed color changes may result from abrasion, sediment transport, chemical dissolution, ultraviolet radiationinduced bleaching, or removal of iron oxides coating the sediment grain.

Ballarini et al. (2003) indicated that bleaching occurs during repeated sun exposure following sediment movement within energetic nearshore environments but did not provide supporting data. The USACE and Bureau of Ocean Energy Management (BOEM) (2013) also suggested that natural sediment reworking and bleaching from sun exposure will lighten dark nourishment sediments but also failed to document sediment color change extent or timeframe. On the basis of similar examples, Pranzini et al. (2010) suggested the development of a standardized approach to determining sediment color and potential color change. This report builds on the notion of standardization to develop a color change capacity index. 
Figure 1-2. Example of dynamic sediment color change following a pilot beach nourishment project near Mobile, Alabama (reproduced from USACE 2013, 71). From left to right, photos represent sediment color immediately following sediment placement, 3.5 weeks post application, and 6.5 weeks postapplication. The sediment color was measured over time, indicating that redder colors transitioned to lighter colors during the monitoring period. However, color changes could not be attributed to any particular mechanism and likely resulted from a combination of mixing with native sand, sediment transport, photochemical bleaching, oxidation, and alteration of iron oxide or other sediment coatings.
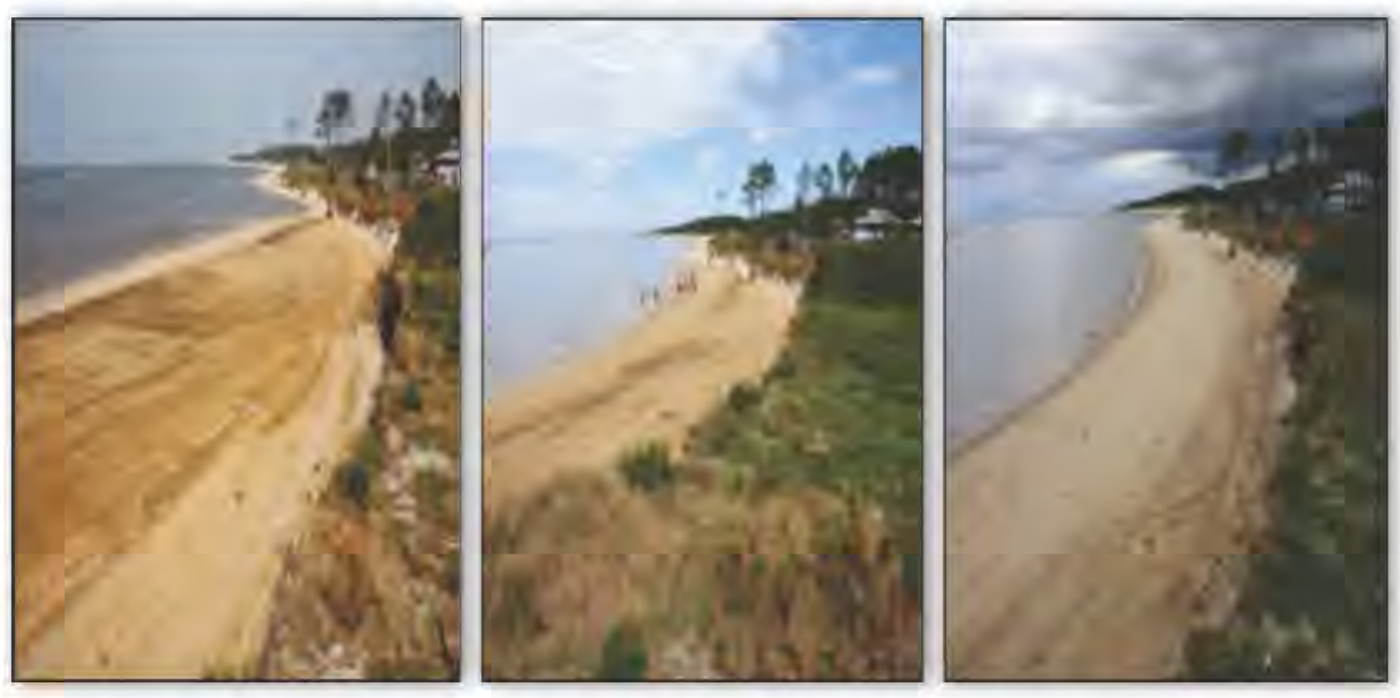

In addition to the limited field studies conducted to date and the anecdotal observations discussed above, several studies discuss using laboratory techniques and manipulations to assess potential color change. For example, Hampton et al. (2004) suggested that chemically treating sediments with hydrogen peroxide could potentially lighten them for improved recreational or environmental outcomes. Yet, few studies systematically investigate potential color change in either laboratory or field settings. One exception includes Thompson Engineering's (2002) study, which attempted to predict potential sediment color changes using hydrogen peroxide and simulated abrasion using a rock tumbler containing a weak (oxalic) acid and an ultraviolet light source. The authors reported that bleaching occurred within 72 hours. However, the report provides limited details about the study conditions (for example, reagent concentration, incubation conditions, replication).

Rabenhorst and Parikh (200o) developed a standardized test methodology to investigate sediment color changes in the laboratory, aiding sediment identification derived from recalcitrant red parent materials (USACE 
2012). Their approach used a series of reducing agents, including ammonium oxalate and citrate dithionite, to remove amorphous and crystalline iron oxide coatings from the sediment surface. The study resulted in the development of a color change propensity index. However, those findings apply specifically to sediments derived from red parent materials (for example, red bed lithologies), limiting direct application to a beneficial use context. The paucity of data investigating sediment color change capacity, especially regarding dredged material management implications, highlights the need for additional research and development of practical tools for practitioners.

\subsection{Objective}

This report addresses the unsuitability of some dredged materials for use in support of infrastructure, recreation, and habitat because of perceived incompatibility between in situ source materials and placement locations. The study provides a detailed methodology and framework for determining the color change potential of dredged materials. This approach allows quantitative documentation of sediment color change dynamics within a beneficial use context. This report also provides a semiquantitative index for rapidly estimating color change potential.

\subsection{Approach}

The report summarizes data and builds upon results from two published studies (Berkowitz et al. 2018; 2018b) and synthesizes color change information into management tools. Specifically, to further investigate potential color change in a beneficial use context, this study investigated potential color changes in sediments from various sources collected throughout the United States. The research evaluated sediment color change potential from three suites of mechanisms (outlined above) to develop a holistic view of color change dynamics. Section 2 reports color changes related to secondary color components using a sequential laboratory approach. Section 3 examines the role of fine sediments and sediment mixing using laboratory mixing experiments and a field demonstration project. Finally, section 4 presents results from controlled light exposure treatments to document the extent of photolytic bleaching on sediment color change. Combining these techniques created a conceptual model for color change potential and provided a framework for differentiating between sediments with low, moderate, and high potential for potential color change (see section 5). The work also provides a protocol for resource 
managers to establish a sediment's likelihood to shift color following beneficial use placement using both quantifiable and rapid semiquantitative approaches. 


\section{Effect of Secondary Color Constituents}

As noted above, sediment mineralogy imparts the base color of parent materials. Subsequent secondary processes such as particle coatings also result in sediment color as materials are eroded from parent rocks and move through the landscape (Giosan et al. 2002). For example, organic carbon accumulation results in particles becoming darker, while organic matter removal (for example, via decomposition) lightens sediment colors. Similarly, iron and manganese oxide coatings impact particle color, and changes in pore water biogeochemistry can alter the stability and color of those (Vasilas and Berkowitz 2016). As a result, potential color change occurs due to changes in secondary color constituents. In response, the following section presents completed study results and provides a protocol for determining potential color changes under laboratory conditions. A full reporting of the study can be found in Berkowitz et al. (2018). These factors, in conjunction with mixing with native sediments and photolytic bleaching effects (described in sections 4.0 and 5.0), define sediment color change potential and help to establish tools for predicting color change dynamics in a dredged material management context (section 6.0).

\subsection{Methods}

A sequential laboratory procedure was developed to examine secondary color constituents in dredged materials. The procedure allows for (1) determination of color change potential and (2) assessment of individual secondary color constituents. This section reports methods and results from Berkowitz et al. (2018), and subsequent sections place this information into a practical context for field practitioners.

Field practitioners working from eight locations associated with navigation, dredged material management, or beach nourishment projects provided sediment samples collected from the upper $30 \mathrm{~cm}$ of submerged borrow areas and navigation channels. Sediment samples varied in mineralogy and particle size distribution (table 2-1). For physical characterization, samples were dried and mechanically sieved at 1 phi intervals. Grain size statistics and sediment classifications were obtained using the program GRADISTAT (Blott and Pye 2001). Sediment mineral compositions were obtained using X-ray diffraction by powdering approximately $50 \mathrm{~g}$ of material from each sample, then passing the material through a $45 \mu \mathrm{m}$ 
mesh sieve and preparing random orientation mounts. Diffraction patterns were gathered from an X-Pert Pro Multipurpose Powder Diffractometer. Munsell color designations were determined using a digital colorimeter (CR 400, Konica Minolta Sensing Singapore) outfitted with an $8 \mathrm{~mm}$ aperture window. The colorimeter was calibrated to a standardized white plate prior to use, as recommended by the manufacturer.

Table 2-1. Sediment sample location, mean particle size $(\mu \mathrm{m}), \mathrm{D}_{50}(\mu \mathrm{m})$, and mineral composition as percent weight of quartz $(\mathrm{Q})$, carbonates $(\mathrm{C})$ and feldspars $(\mathrm{F})$. Note that sediments used in the study represent a variety of geographic source locations, grain sizes, and mineral compositions. Adapted from Berkowitz et al. $(2018,1151)$.

\begin{tabular}{|c|c|c|c|c|c|c|c|}
\hline Sample & Source & Location & $\begin{array}{l}\text { Mean size } \\
(\mu \mathrm{m})\end{array}$ & $\begin{array}{l}D_{50} \\
(\mu \mathrm{m})\end{array}$ & Q & C & $\mathrm{F}$ \\
\hline FL1 & Siesta Key, FL & $\begin{array}{l}\text { Offshore borrow } \\
\text { area }\end{array}$ & 359 & 348 & 41 & 59 & 0 \\
\hline TX1 & Galveston, TX & $\begin{array}{l}\text { Galveston } \\
\text { entrance channel }\end{array}$ & 262 & 193 & 71 & 13 & 16 \\
\hline FL2 & $\begin{array}{l}\text { Egmont Key, } \\
\text { FL }\end{array}$ & $\begin{array}{l}\text { Tampa entrance } \\
\text { channel }\end{array}$ & 419 & 425 & 49 & 36 & 3 \\
\hline CA1 & Ventura, CA & Ventura harbor & 228 & 236 & 35 & 1 & 64 \\
\hline FL3 & Miami, FL & $\begin{array}{l}\text { Offshore borrow } \\
\text { area }\end{array}$ & 562 & 581 & 38 & 62 & 0 \\
\hline MD1 & $\begin{array}{l}\text { Ocean City, } \\
\text { MD }\end{array}$ & $\begin{array}{l}\text { Offshore shoal } \\
\text { area }\end{array}$ & 327 & 338 & 77 & 0 & 23 \\
\hline PA1 & $\begin{array}{l}\text { Philadelphia, } \\
\text { PA }\end{array}$ & $\begin{array}{l}\text { Offshore borrow } \\
\text { area }\end{array}$ & 325 & 340 & 97 & 0 & 3 \\
\hline AL1 & Jackson, AL & $\begin{array}{l}\text { Tombigbee River } \\
\text { channel }\end{array}$ & 314 & 332 & 99 & 1 & 0 \\
\hline
\end{tabular}

Changes to sediment color were examined by applying a sequential chemical treatment, during which sediment color was recorded at the following states: (1) the untreated condition, (2) following the dissolution of carbonates, (3) oxidation of organic matter, (4) removal of amorphous iron oxides, and (5) removal of crystalline iron oxides. Following each treatment, a subsample of sediment was collected for color determination. Measurements were taken across six locations on the sediment surface after each treatment, then averaged. This approach yielded low variability between repeated color measurements, with maximum observed standard error of $0.30,0.08$, and 0.05 for Munsell hue, value, and chroma color components respectively. Similar reproducibility was reported by Rabenhorst and Parikh (200o), who conducted replicate color measurements at four locations. All measurements were taken in the moist state, 
and sediment colors were reported to the nearest 0.1 for hue, value, and chroma. Hues were converted to a numerical scale as described by Rabenhorst and Parikh (2000), so that $10 \mathrm{R}=10,5 \mathrm{YR}=15,10 \mathrm{YR}=20$, and $5 \mathrm{Y}=25$.

Three sediment samples (FL1, TX1, FL2) contained enough material to replicate the analysis five times to examine variability and apply statistical testing at each treatment phase. Statistical analyses included ANOVA followed by post hoc testing with Tukey's test. All model assumptions were met, including normality (Shapiro-Wilk test) and homogeneity of variance (Levene's test). All statistical significance was determined at $\alpha=0.05$ level using SPSS version 24 (IBM). The chemical treatments used in the study are described in the following subsections.

\subsubsection{Removal of carbonate}

Carbonate removal included applying a 1 molar sodium acetate buffer to $20 \mathrm{~g}$ of sediment, followed by stirring and incubation in an $80^{\circ} \mathrm{C}$ water bath for $30 \mathrm{~min}$. The treatment was repeated using fresh buffer solution resulting in a $1 \mathrm{hr}$ total incubation time with stirring at 15 min intervals (Reddy et al. 2013; Soukup et al. 2008).

\subsubsection{Removal of organic matter}

Organic matter oxidation used $10 \mathrm{~mL}$ of $1 \mathrm{M}$ sodium acetate buffer and 130 $\mathrm{mL}$ of $35 \%$ hydrogen peroxide incubated in a $65^{\circ} \mathrm{C}$ water bath for $30 \mathrm{~min}$ with stirring at $15 \mathrm{~min}$ intervals (Kunze and Dixon 1986). The treatment was repeated using fresh buffer solution, resulting in a $1 \mathrm{hr}$ total incubation time. The sodium acetate buffer maintained $\mathrm{pH}$ near 5.0 to optimize organic matter removal (Mikutta et al. 2005).

\subsubsection{Removal of iron coatings}

Amorphous iron oxide sediment coatings were removed by adding $5 \mathrm{~g}$ of sodium dithionate and $70 \mathrm{~mL}$ of $0.06 \mathrm{M}$ citrate buffer to each sediment sample, with stirring at $15 \mathrm{~min}$ intervals for $1 \mathrm{hr}$ at $25^{\circ} \mathrm{C}$ (Rabenhorst and Parikh, 2000). More recalcitrant crystalline iron oxide coatings were removed by adding $5 \mathrm{~g}$ sodium dithionate and $70 \mathrm{~mL}$ of $0.06 \mathrm{M}$ citrate buffer followed by incubation in an $80^{\circ} \mathrm{C}$ water bath for $2 \mathrm{hr}$ with stirring at 15 min intervals (Soukup et al. 2008). The treatment was repeated using fresh reagent, resulting in a $4 \mathrm{hr}$ total incubation time. 


\subsection{Results and discussion}

The removal of carbonates, organic matter, and iron oxide coatings increased the Munsell value within each of the samples examined (figure 2-1). Munsell value increased from $4.5 \pm 0.07$ (average \pm standard error) to $5.5 \pm 0.1$ representing an average increase in brightness of approximately 1.o Munsell value unit, which is clearly visible to the human eye (figure 2-2). For sediment samples with sufficient replication, increases were statistically significant. As noted elsewhere, organic matter darkens sediment colors, and the removal of organic matter causes sediments to appear lighter in color. As a result, organic matter removal resulted in the majority of the observed sediment color changes. Additionally, the removal of organic matter by natural processes (oxidation) would likely occur following beneficial use applications that expose sediments to air, higher temperatures, and increased microbial activity. Sediments also displayed increases in Munsell value with the removal of iron oxide coatings, which can impart dark red colors to the sediment surface.

Munsell chroma also responded to the chemical treatments (figure 2-3). Treatments resulted in a Munsell chroma decrease from $1.7 \pm 0.1$ (average \pm standard error) to $0.9 \pm 0.09$, a statistically significant decrease. Changes were visible to the unaided human eye. A subset of the sediments initially increased in Munsell chroma following removal of organic matter, but chroma later declined with reduction of iron oxides. This result (although not intuitive) was not unexpected, since organic matter masks sediment particles, and removing organic coatings exposes higher chroma sediment surfaces, which can subsequently be removed in later treatments. Vepraskas et al. (2016) and Vasilas and Berkowitz (2016) provide related examples of low chroma color development in a wetland soil context, and Giosan et al. (2002) provides an example of identification of low chroma sediment layers within a marine geology context.

Munsell hue results displayed more variability than value and chroma color components (figure 2-4), with several samples displaying large changes in hue during removal of carbonates and organic matter. Other samples responded to the iron oxide removal. Changes in hue varied in intensity, with some samples displaying prominent hue shifts while other samples displayed faint shifts. Most sediments examined remained in the expected range of yellow-red to yellow (numerical designation $12.5^{-} 30$ ). However, one sample (FL1) exceeded those values, displaying colors within the yellow-green spectral range (numerical designation 30-40) following iron oxide removal. 
Figure 2-1. Munsell value determined in eight sediment samples throughout the sequential laboratory procedure. Where available, measurements with unique letter designations were statistically different at the $\alpha=0.05$ level. The dashed line represents a commonly applied color requirement threshold of $\geq 5.0$. Adapted from

Berkowitz et al. $(2018,1152)$.
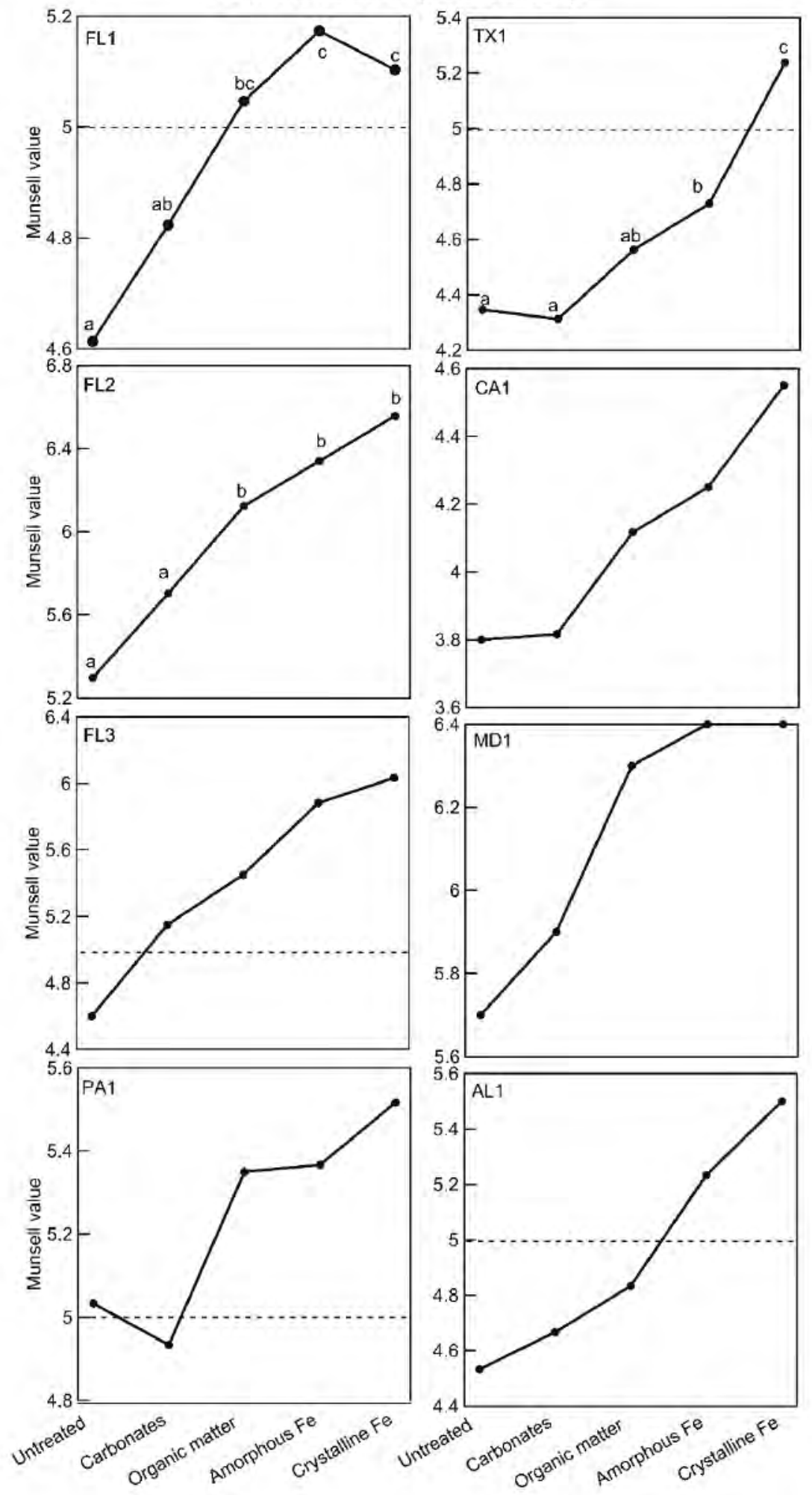
Figure 2-2. Munsell chroma determined in eight sediment samples throughout the sequential laboratory procedure. Where available, measurements with unique letter designations were statistically different at the $\alpha=0.05$ level. The dashed line represents a commonly applied color requirement threshold of $\leq 2.0$. Adapted from

Berkowitz et al. $(2018,1153)$.
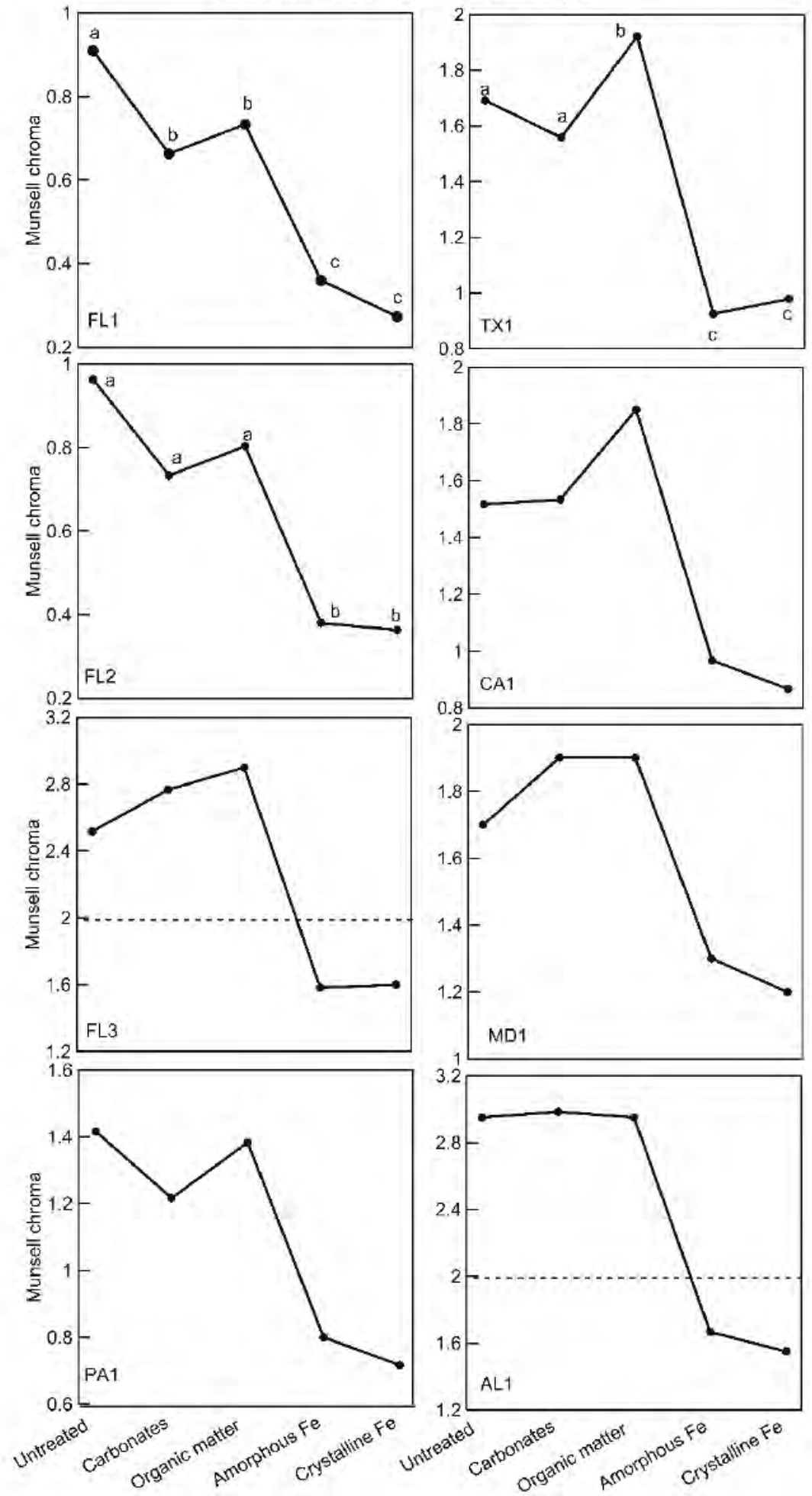
Figure 2-3. Munsell hue determined in eight sediment samples throughout the sequential laboratory procedure. Where available, measurements with unique letter designations were statistically different at the $\alpha=0.05$ level. Adapted from Berkowitz et al. $(2018,1153)$.
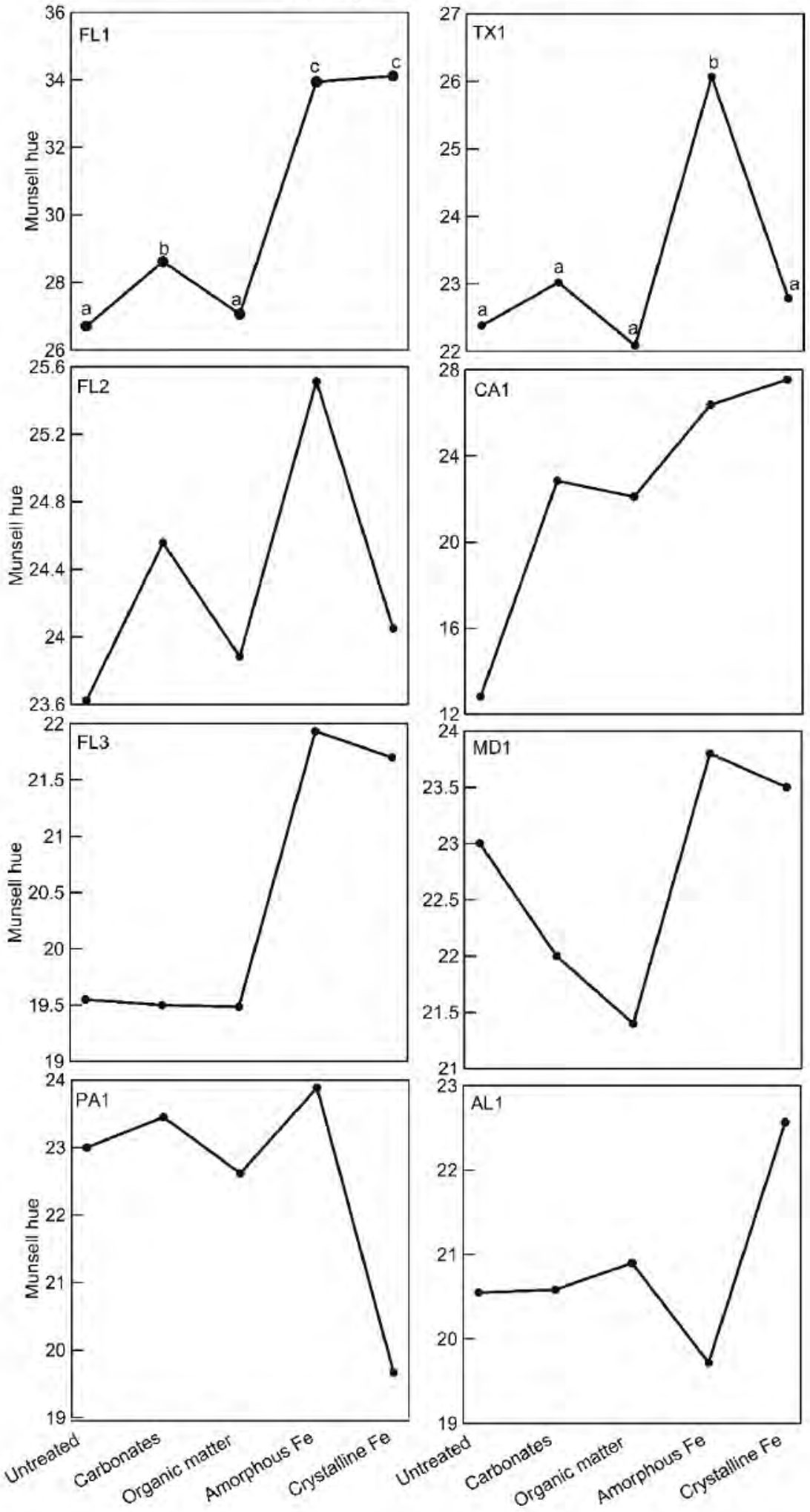
Study results demonstrate that (1) visible color shifts can occur following sample treatments designed to simulate post-beneficial use conditions and (2) observed color changes yielded sediment more compatible with aesthetic and habitat preferences (figure 2-4). For example, Munsell value thresholds require that sediments used in beach nourishment projects exhibit a value of $\geq 5$. o or $\geq 6$. o (table 2-1). Applying the $\geq 5$. o threshold to the current data set, two samples exhibited acceptable Munsell values in an untreated condition and would remain unproblematic for most beach nourishment applications. One of the samples examined (CA1), failed to surpass the Munsell value threshold throughout the sequential laboratory procedure, displaying a low propensity to brighten. The remaining five sediment samples displayed the capacity for color change beyond the Munsell value threshold of 5.0. Observed increases of Munsell value are within the range reported in USACE's (2013) report, which indicated an average Munsell value increase of 1.4 units within 12 months of beach nourishment application under field conditions. Maglio et al. (2015) reported similar increases in Munsell value units (o.6-1.5) following placement using various placement techniques. The significance of these findings suggest that those samples may represent potential source materials for beach nourishment applications despite the fact that they fail to meet Munsell color requirements in an untreated (in situ) condition.

Figure 2-4. The sequential removal of secondary color constituents resulted in a visible change in sediment color from in situ condition (left) dominated by a lightening of the sediments due to an increase in Munsell value and a decrease in the Munsell chroma (right). Color changes remain visible to the human eye, with color shifts resulting in more desirable color characteristics for aesthetics and habitat suitability. Adapted from Berkowitz et al. (2018b, 54).

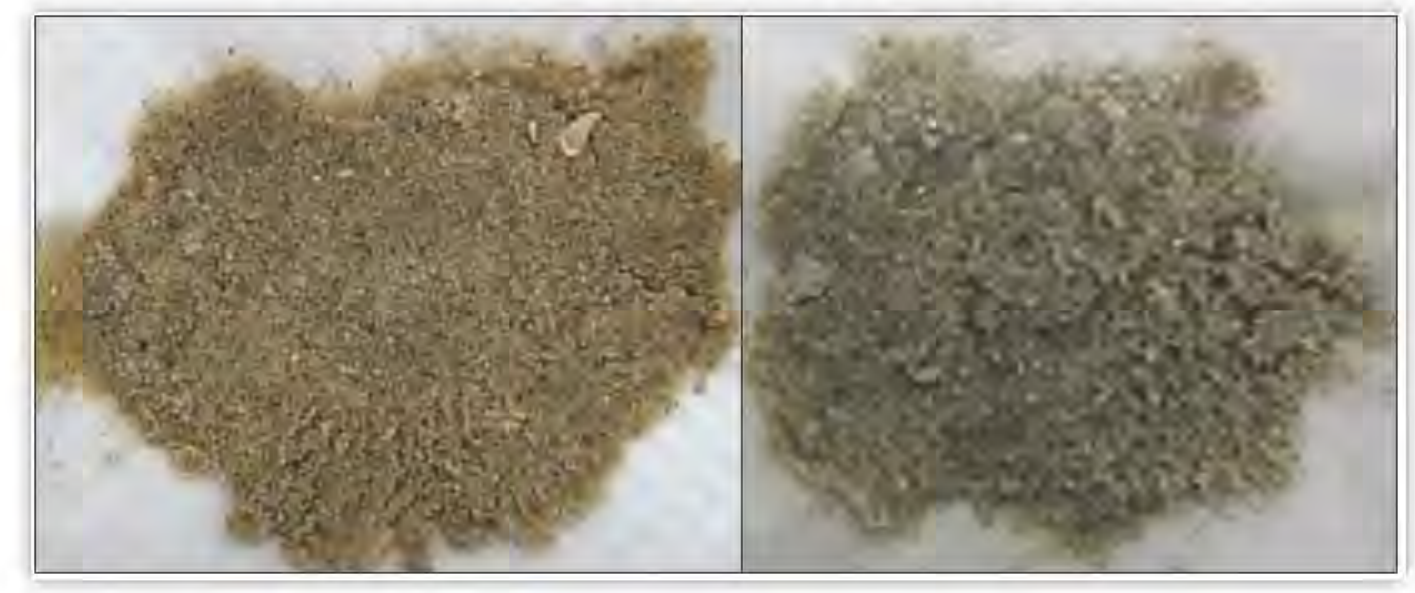


Notably, the degree of Munsell value change potential varied by sediment sample, suggesting that sediment lightness or darkness was associated with organic matter, iron coatings, and mineralogy. For example, three sediment samples surpassed the Munsell value threshold during the organic matter removal process, suggesting that color change may occur rapidly following exposure to aerobic conditions, wetting, drying, light, and heat associated with onshore or nearshore environmental conditions. Two samples surpassed the threshold during the procedure's iron coating removal phase; one sample exceeded requirements during amorphous material removal, and the other required removal of crystalline iron from the sediment surface. Findings suggest that samples surpassing Munsell value thresholds during iron removal have the capacity for color change yet remain more recalcitrant than those samples responding to organic matter removal.

Similarly, some beach nourishment requirements limit sediment applications to low chroma materials, typically those displaying chroma $\leq 2.0$, although a subset of projects require Munsell chroma to remain $\leq 1.0$ (table 2-1). Within the current dataset, six of the sediments exhibited a chroma below 2.o in an untreated condition, two of which displayed chroma below 1.o before treatment. These sediments would be acceptable for beach nourishment application from a Munsell chroma sediment color perspective. The remaining sediment samples surpassed the Munsell chroma threshold of $\leq 2$.o during removal of iron oxide coatings, suggesting that those materials may display adequate color shifts to be considered as source materials for beach nourishment, depending on the persistence of iron oxide coatings following sediment placement.

Due to the high degree of variability in response to laboratory procedures, results suggest that Munsell hue may provide a less predictable indicator of both aesthetic and environmental compatibility than chroma and value color components for determining a sediment's capacity to change color.

Establishing a definitive link between sediment color changes by removal of certain constituents via chemical treatments versus in situ processes requires additional research including field trials. However, because the laboratory treatments successfully differentiated between sediment samples with low and high color change potential, it may provide a useful proxy for 
potential color change. Using these findings, a categorical scheme was developed to communicate potential color change capacity to resource managers (see section 6 below).

Samples FL2 and MD1 met color requirements in an untreated condition and would be acceptable for beach nourishment applications in their current form. Samples FL1, FL3, AL1, TX1, and PA1 all lightened beyond requirement thresholds (value $\geq 5$ ) following chemical treatments. These sediments would be expected to shift color toward desired criteria (for example, high Munsell value, low chroma) following beach nourishment application if those constituents were equivalently removed or altered by physical or photolytic (bleaching) processes. For example, some of these samples responded to carbonate and organic matter removal, while others required removal of iron oxides before surpassing sediment color suitability thresholds. Finally, as mentioned above, sample CA1 failed to sufficiently lighten after treatment and would likely be rejected for use in beach nourishment. Understanding the propensity of sediments to change color increases the availability, and responsible use, of limited sediment resources by allowing sediments that initially do not meet color compatibility requirements to be used in coastal restoration projects. Further research is needed to incorporate other color change mechanisms (for example, sediment mixing, transport, photolysis) into a comprehensive screening tool that assesses sediment color change capacity.

\subsection{Summary}

Many beach nourishment projects use sediment color as a compatibility factor to ensure that source material is both aesthetic and suitable for habitat. However, sediment color requirements remain poorly defined, potentially limiting the amount of sediment available for such applications. A series of chemical treatments was applied to dredged materials to investigate potential color shifts due to changes in secondary color constituents. Following the treatments, significant increases in Munsell value and decreases in Munsell chroma were associated with the removal of carbonates, organic matter, and iron oxides. Thus, the chemical treatments provide insight into the degree of color change potential that may be achieved if such constituents were removed by chemical or physical processes following beneficial use placement. As a result, the current study provides a repeatable methodology to develop proxy measurements of color change capacity for sediments. These findings, in combination with color shifts related to mixing and bleaching, support development of a framework for determining the color change potential of dredged sediments. 


\section{Effect of Fines and Sediment Mixing}

This section examines the color attributes and changes associated with moisture, grain size, and sediment composition, in addition to sediment mixing and mud content, through laboratory experiments and from samples collected in the field.

The first phase investigated the effect of moisture and sediment composition on color attributes and served to establish baseline conditions. The second phase investigated the relationships between mud content, sediment mixing, and corresponding changes in Munsell value. Specifically, this second phase established (1) a functional relation between percent fines and sediment lightness; (2) determined the fraction of fines (by mass) added to clean, fine sand required to lower the Munsell value below a critical threshold of 5.0; and (3) determined the change in color attributes resulting from mixing clean sand with darker dredged material.

\subsection{Coloration according to moisture, composition, and grain size}

\subsubsection{Materials}

A total of 36 samples were retrieved from various active USACE dredging projects from nine geographic locations around the country. Of those, the samples selected for color analysis are presented in table 3-1.

Table 3-1. Locations and IDs of samples used for color analysis.

\begin{tabular}{|c|c|c|c|c|c|}
\hline Sample ID & Location & $\begin{array}{c}\text { Date } \\
\text { Collected }\end{array}$ & Latitude & Longitude & $\begin{array}{c}\text { Other } \\
\text { Identifiers/Attrib } \\
\text { utes }\end{array}$ \\
\hline SK1* & Siesta Key, FL & - & - & - & $\begin{array}{l}\text { A1 Cores 1-6 } \\
\text { (Borrow area) }\end{array}$ \\
\hline SK2 & Siesta Key, FL & - & - & - & $\begin{array}{l}\text { A1 Cores 6-13 } \\
\text { (Borrow area) }\end{array}$ \\
\hline SK3 & Siesta Key, FL & - & - & - & $\begin{array}{l}\text { A3 Cores 1-5 } \\
\text { (Borrow area) }\end{array}$ \\
\hline SK4 & Siesta Key, FL & - & - & - & $\begin{array}{l}\text { A3 Cores 6-10 } \\
\text { (Borrow area) }\end{array}$ \\
\hline SK5 & Siesta Key, FL & - & - & - & A4 (Borrow area) \\
\hline GS6 & Galveston, TX & 15-Dec-2015 & 29.26213 & -94.83362 & $\begin{array}{l}\text { 0-30" deep; } \\
\text { mixed sample }\end{array}$ \\
\hline GS7 & Galveston, TX & 15-Dec-2015 & 29.26213 & -94.83362 & $\begin{array}{l}\text { 0-15" deep; } \\
\text { sandy sample }\end{array}$ \\
\hline
\end{tabular}




\begin{tabular}{|c|c|c|c|c|c|}
\hline Sample ID & Location & $\begin{array}{c}\text { Date } \\
\text { Collected }\end{array}$ & Latitude & Longitude & $\begin{array}{c}\text { Other } \\
\text { Identifiers/Attrib } \\
\text { utes }\end{array}$ \\
\hline GS8* & Galveston, TX & 15-Dec-2015 & 29.26213 & -94.83362 & $\begin{array}{l}\text { 6-30" deep; shell } \\
\text { silt sample }\end{array}$ \\
\hline GS9 & Galveston, TX & 11-Sep-2015 & 29.25850 & -94.82433 & Postfill \\
\hline EK10 & $\begin{array}{l}\text { Egmont Key, } \\
\text { FL }\end{array}$ & 20-Nov-2014 & 27.60268 & -82.76233 & - \\
\hline EK11* & $\begin{array}{l}\text { Egmont Key, } \\
\text { FL }\end{array}$ & 20-Nov-2014 & 26.60260 & -82.76248 & - \\
\hline EK12 & $\begin{array}{l}\text { Egmont Key, } \\
\text { FL }\end{array}$ & - & 27.59977 & -82.76329 & Prefill North \\
\hline EK13 & $\begin{array}{l}\text { Egmont Key, } \\
\text { FL }\end{array}$ & - & 27.59181 & -82.76329 & Prefill Middle \\
\hline EK14 & $\begin{array}{l}\text { Egmont Key, } \\
\text { FL }\end{array}$ & - & 27.58346 & -82.76399 & Prefill South \\
\hline VH15 & $\begin{array}{l}\text { Ventura } \\
\text { Harbor, CA }\end{array}$ & 10-Feb-2016 & 34.24765 & -119.27025 & Area D Brown \\
\hline VH16 & $\begin{array}{l}\text { Ventura } \\
\text { Harbor, CA }\end{array}$ & 16-Feb-2016 & 34.24697 & -119.27067 & Area D Brown \\
\hline VH17* & $\begin{array}{l}\text { Ventura } \\
\text { Harbor, CA }\end{array}$ & 24-Feb-2016 & 34.24716 & -119.27040 & Area D Brown \\
\hline VH18 & $\begin{array}{l}\text { Ventura } \\
\text { Harbor, CA }\end{array}$ & 10-Feb-2016 & 34.23990 & -119.26565 & $\begin{array}{l}\text { Beach Kavika Tai } \\
\text { Tai }\end{array}$ \\
\hline VH19 & $\begin{array}{l}\text { Ventura } \\
\text { Harbor, CA }\end{array}$ & 18-Feb-2016 & 34.23990 & -119.26565 & $\begin{array}{l}\text { Beach Kavika Tai } \\
\text { Tai }\end{array}$ \\
\hline VH2O & $\begin{array}{l}\text { Ventura } \\
\text { Harbor, CA }\end{array}$ & 24-Feb-2016 & 34.23990 & -119.26565 & $\begin{array}{l}\text { Beach Kavika Tai } \\
\text { Tai }\end{array}$ \\
\hline M21 & Miami, FL & Jan 2016 & - & - & $\begin{array}{l}\text { Surf Club CCCL } \\
\text { project }\end{array}$ \\
\hline M22* & Miami, FL & Jan 2016 & - & - & $\begin{array}{l}\text { Surf Club CCCL } \\
\text { project }\end{array}$ \\
\hline M23 & Miami, FL & Jan 2016 & - & - & $\begin{array}{l}\text { Surf Club CCCL } \\
\text { project }\end{array}$ \\
\hline $\mathrm{HH} 24 *$ & $\begin{array}{l}\text { Huntington } \\
\text { Harbor, CA }\end{array}$ & 26-Feb-2016 & 33.71730 & -118.08038 & $\begin{array}{l}\text { Entrance } \\
\text { Channel, in situ }\end{array}$ \\
\hline РH30* & $\begin{array}{l}\text { Philadelphia, } \\
\text { PA }\end{array}$ & - & - & - & $\begin{array}{l}\text { Long Beach } \\
\text { Island }\end{array}$ \\
\hline AL33* & Jackson, AL & 24-June-2016 & 31.390136 & -87.892750 & $\begin{array}{l}\text { Sunflower } \\
\text { Disposal Site }\end{array}$ \\
\hline MD36* & $\begin{array}{l}\text { Ocean City, } \\
\text { MD }\end{array}$ & 12-July-2016 & - & - & $\begin{array}{l}\text { Isle of Wight } \\
\text { Shoal }\end{array}$ \\
\hline
\end{tabular}




\subsubsection{Methods}

\subsubsection{Particle size analysis}

Samples were oven dried and mechanically sieved at 1 phi size classes. Grain size statistics and textural classifications were obtained using the program GRADISTAT (Blott and Pye 2001). Sample statistics are reported using the geometric method of moments per Folk and Ward (1957).

\subsubsection{Mineral composition}

Semiquantitative analysis of mineral composition was determined using $\mathrm{X}$-ray diffraction performed by personnel at the ERDC Geotechnical and Structures Laboratory. Approximately $50 \mathrm{~g}$ of material was collected using a riffle splitter to maintain sample representativeness. Samples were then powdered, passed through a 45 um (no. 325) mesh sieve, and prepared as random orientation mounts. Diffraction patterns were gathered from an X-Pert Pro Multipurpose Powder Diffractometer that uses standard techniques and software for mineral identification and semiquantitative analysis (by wt\%).

\subsubsection{Color measurements}

Sediment color was measured using a Konica-Minolta CR-400 colorimeter. The colorimeter measures color absorbance according to the change in light intensity in the red, green, and blue spectra due to absorbance by the target material. The CR-40o reports the color of objects within the Munsell color space, characterized by hue, value, and chroma (HVC). The Munsell color space is a three-dimensional, empirically based color system where, essentially, the hue refers to the object's color (red, orange, yellow, etc.), value refers to its lightness ( $\mathrm{o}=$ black, 10 = white), and chroma refers to its saturation (Malacara 2011).

The CR-40o measuring head is fitted with a light projection tube to impede ambient light from interfering with the measurement. The instrument's calibration was checked against a standard white plate prior to each use.

Color attributes were measured as bulk sediment color and by size class. For bulk attributes, measurements were taken in the dry and moist states. For moist color analysis, samples were wetted (but not to the point of saturation, to prevent infiltration of the fines), thoroughly mixed, and placed 
in a $10 \mathrm{~cm}$ diameter petri dish to a depth of about $1 \mathrm{~cm}$. Each sample was photographed, then color measurements were taken on the surface using a consistent three-point pattern to obtain an average for the bulk sample.

For color measurements by size class, one sample from each location was selected to measure the color of sediment retained within each size class from mechanical sieving. A subsample from each size class was photographed and analyzed for color within an aluminum well $4 \mathrm{~cm}$ in diameter and $4 \mathrm{~mm}$ deep. Three measurements were made at the center point for each sample and averaged. These measurements were performed in the dry condition only.

\subsubsection{Results and discussion}

\subsubsection{Particle size analysis}

Gradations of the samples varied within and between sample locations, which consisted of fine to coarse sands and were poorly to well-sorted. The finest sediments were from the Huntington Harbor location, while the coarsest were from Miami. Samples GS8, EK10-12, and VH14 contained between $5^{-20}$ wt\% of coarse shell fragments. Except for HH27, none of the other samples analyzed for color had any appreciable quantity of material in the silt and clay size classes (all $<1.0 \%$ ). Table $3-2$ lists textual classes and grain-size statistics.

\begin{tabular}{llllll} 
Table 3-2. Summarized grain size statistics of representative sediment samples used \\
in the color analysis. & & \\
Location & D $_{10}$ & D50 & D90 $_{9}$ & Sorting & Textural class \\
\hline \hline Miami, FL & 280 & 581 & 1273 & Moderate & Coarse sand \\
Egmont Key, FL & 126 & 425 & 2085 & Poor & Med-coarse sand \\
Siesta Key, FL & 144 & 348 & 955 & Poor & Medium sand \\
Philadelphia, PA & 168 & 340 & 680 & Mod. well & Medium sand \\
Ocean City, MD & 173 & 338 & 517 & Mod. well & Medium sand \\
\hline Jackson, AL & 159 & 332 & 653 & Moderate & Medium sand \\
Galveston, TX & 122 & 193 & 1440 & Poor & Medium sand \\
Ventura Harbor, CA & 122 & 236 & 406 & Mod. well & Fine-med sand \\
Huntington Harbor, CA & 95 & 135 & 227 & Mod. well & Fine sand
\end{tabular}




\subsubsection{Mineralogy}

Samples from Siesta Key, Egmont Key, Philadelphia, and Jackson, Alabama, were composed of predominantly quartz and carbonate. Conversely, Galveston, Ventura Harbor, Huntington Harbor, and Ocean City contained appreciable to dominant quantities of feldspar (table 3-3). The carbonate fraction is mostly in the form of aragonite from shell material. Sediments retained on the $0.50 \mathrm{~mm}$ (1phi) sieve or greater were observed to be mostly shell material, while quartz appeared to comprise the majority of sediments less than $0.125 \mathrm{~mm}$ (3 phi). The sample from Huntington Harbor contained a significant amount of micas (22\%). Figure 3-1 provides close-up images of representative samples from the nine sample sites.

$\begin{aligned} & \text { Table 3-3. Mineral constituents (est. wt\%) of representative samples used in the } \\
& \text { Phase I color analysis. }\end{aligned}$
\begin{tabular}{lllllll} 
Location & Quartz & Carbonate & Feldspar & Phyllosilicate & Other \\
\hline Jackson, AL & 100 & $<1$ & 0 & 0 & 0 \\
Philadelphia, PA & 97 & 0 & 4 & 0 & 0 \\
Ocean City, MD & 77 & 0 & 22 & 0 & 1 \\
\hline Galveston, TX & 71 & 13 & 16 & 0 & 0 \\
Egmont Key, FL & 49 & 36 & 3 & 0 & 0 \\
Siesta Key, FL & 41 & 59 & 0 & 0 & 0 \\
Miami, FL & 38 & 62 & 0 & 0 & 0 \\
Ventura Harbor, CA & 35 & 1 & 64 & 0 & 0 \\
Huntington Harbor, CA & 24 & 0 & 52 & 22 & 3
\end{tabular}


Figure 3-1. Close-up photographs of representative samples from each location used in the X-ray diffraction analysis. Siesta Key, FL (A); Galveston, TX (B); Egmont Key, FL

(C); Ventura Harbor, CA (D); Miami, FL (E); Jackson, AL (F); Ocean City, MD (G);

Philadelphia, PA (H); and Huntington Harbor, CA (I). Scale bar (red lines) denotes 2 $\mathrm{mm}$ in each image. It is important to note that the sediment color in the images is not necessarily what is perceived by the human eye in sunlight conditions. Images courtesy of Erin Gore, ERDC Geotechnical and Structures Laboratory.

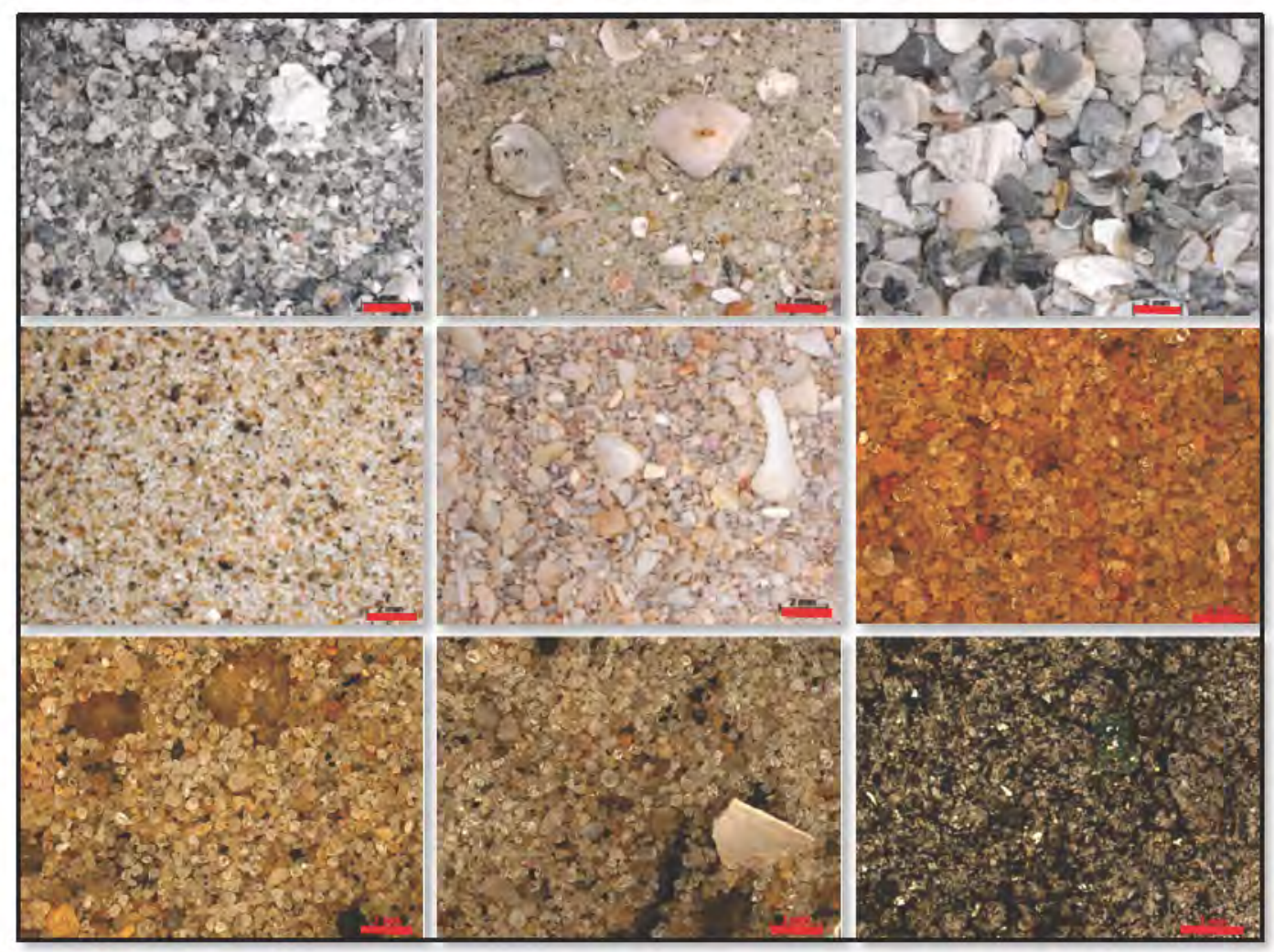

\subsubsection{Munsell color classification}

The colorimeter measurements showed excellent repeatability; variations in HVC values were typically \pm 0.1 unit.

Nearly all the samples were in the yellow hue domain-the exception being the Miami samples, which plot slightly in the yellow-red domain (figure $3^{-2}$ ). However, the samples typically had very low chroma values, meaning the color appears more neutral, defined as having values <2.0. Only the Miami and Jackson, Alabama, samples slightly exceeded this.

The bulk sediment color measurements between the dry and moist states showed little differences in the hue and chroma parameters but marked differences in Munsell value (table A1). On average, hue shifted slightly by 
approximately 1 unit toward the yellow spectrum, whereas chroma exhibited almost no change despite the perceived increase in color saturation by visual observation. Moist sediments appeared darker than dry sediments, indicated as a change in value by an average of 1.7 units. Samples in the dry state often exhibited values of about 6.0 or higher but decreased to about 4.0 to 5.0 in the moist state.

Figure 3-2. Sediment samples (moist state) plotted in the Munsell color space.

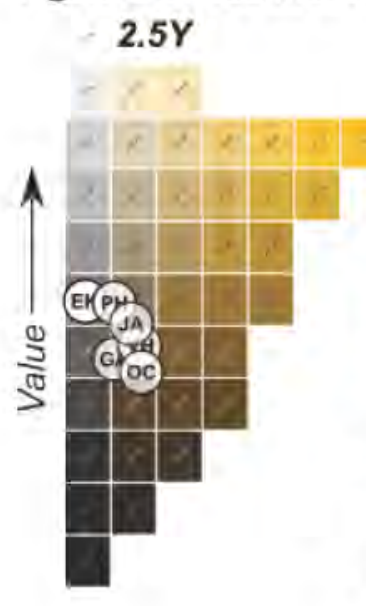

$7.5 Y$

\subsection{YR}

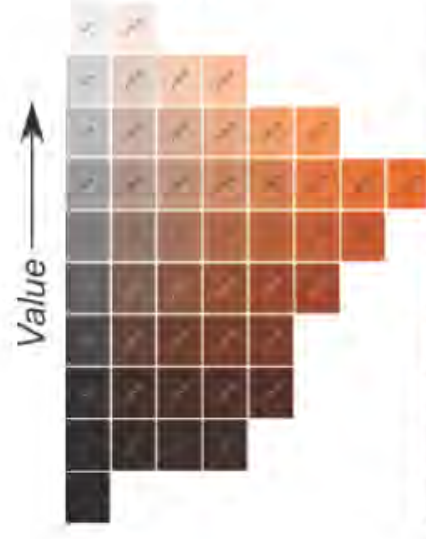

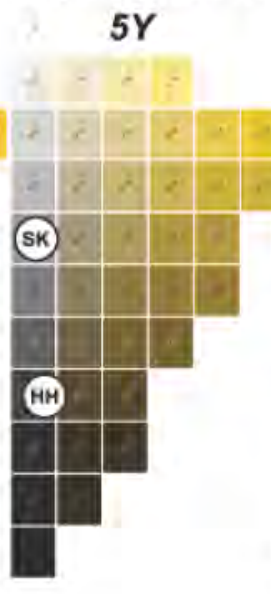

5YR

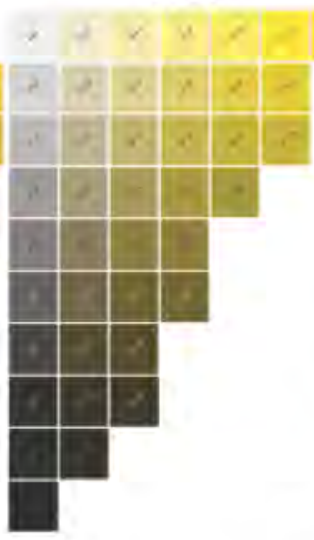

$7.5 Y R$

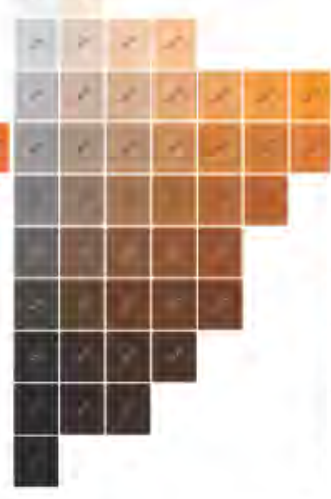

Chroma
$10 \mathrm{Y}$

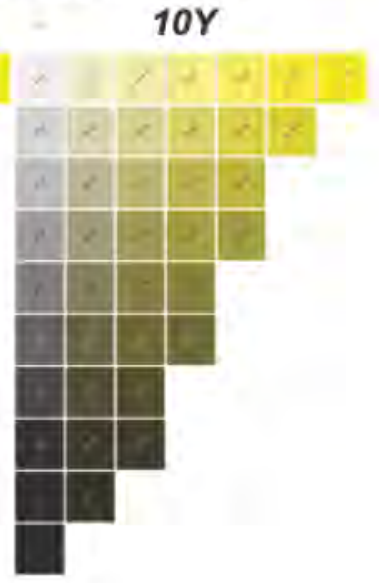

$10 Y R$

Mineral composition plays a dominant role in sediment color. Therefore, it was instructive to examine color variations between grain size classes. Color measurements by size class revealed that some sediments became lighter with decreasing size class, since light-colored quartz particles dominated small size classes; particles in the larger size classes were typically darker-colored shell fragments (table A2). On the other hand, some sediments were darker with decreasing size class in cases where there was a 
more significant fraction of fines or heavy minerals (for example, samples $\mathrm{HH} 24$ and HH27). In all of the above cases, sediment color and brightness were due only to mineral constituents or sediment staining (such as the Jackson, Alabama sample). Figures A1-A9 in appendix A present a visual comparison of color between bulk samples and their corresponding size classes. Table A2 presents the color data.

The sediments investigated here are comprised of silicates and carbonates. At first order, the primary driver of lightness values in beach sediments appears to be the relative abundance of quartz grains, as the carbonate shell fragments in these samples appear darker. Samples with considerable carbonate minerals may lighten over time from sunlight exposure due to the breakdown of pigments in the shell. However, shell fragments that have been phosphatized may not lighten considerably, or at all. Likewise, siliciclastic sediments will not lighten, since their color is an intrinsic property of their crystalline structure and composition. In the absence of mud, organic matter, and staining, the overall hue and brightness can also be attributed to the abundances of feldspars and rock fragments relative to quartz. Quartz grains may appear either colorless or translucent gray. Therefore, sediments with high gray quartz percentages may appear slightly darker than their colorless variety.

\subsection{Munsell value changes due to mud content and sediment mixing}

The sediments used in the previous section had virtually no silt or clay in order to examine brightness shifts as a function of fines content. Therefore, a simple desktop experiment was conducted in which dark, fine sediment was mixed with clean, bright sand to establish a relationship between Munsell value and the fraction of fines.

\subsubsection{Materials}

Three sources of sediment were used for the laboratory testing: a commercial grade, fine quartz sand (QS); a locally sourced loess referred to as Vicksburg silt (VS); and a mud obtained from the banks of the Mississippi River (MS). The QS is near pure ( $>99 \%$ quartz) and has a narrow size distribution $\left(d_{50}=186 \mu m, d_{10}=117 \mu m, d_{90}=295 \mu m\right)$. The Vicksburg silt is also very uniform $\left(d_{50}=23 \mu \mathrm{m}, d_{10}=7 \mu \mathrm{m}, d_{90}=49 \mu \mathrm{m}\right)$ and consists of less than $3 \%$ clay. The Mississippi River sediment is classified as a fine silt and consists of $3 \%$ sand, $82 \%$ silt, and $16 \%$ clay with a $d_{50}=35 \mu \mathrm{m}$. The VS and MS sediments were dried and sieved through a $75 \mu \mathrm{m}$ (no. 
200) test sieve so that only the fines fractions were used in the mixing experiments. The initial Munsell value of QS, absent of any fines, was 6.1 in the moist state. In comparison, the pure VS and MS sediment had MVs of 4.2 and 2.7, respectively, thus indicating that the MS mud was particularly dark. These initial values represent the end-member states that a mixture of the constituents must evolve between. Images of representative sediment samples used in the experiments are displayed in figure 3-3.

Figure 3-3. Representative sediment samples in the moist state used in the mixing experiment. $A$ is the pure quartz sand (QS); $B$ is the Vicksburg silt (VS); and C is Mississippi River mud (MS). Samples from VS and MS were screened through a 75 $\mu \mathrm{m}$ mesh sieve prior to mixing. The initial Munsell value of each sample is indicated in the lower left $(6.1,4.2$, and 2.7 , respectively).

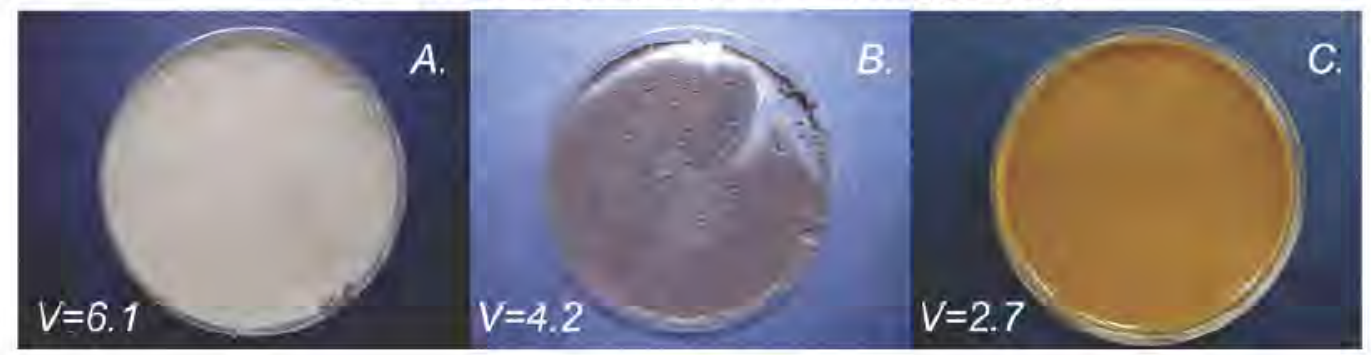

\subsubsection{Methods}

The VS and MS sediments were added to $50 \mathrm{~g}$ of QS sand in the following proportions by mass: $2 \%, 4 \%, 6 \%, 8 \%, 10 \%, 15 \%, 20 \%$, and $25 \%$. Each sample was thoroughly mixed in the moist (but unsaturated) state, then samples were placed in a $10 \mathrm{~cm}$ diameter petri dish to a depth of about 1 $\mathrm{cm}$. Each sample was photographed, then color measurements were taken on the surface using three different locations.

\subsubsection{Results and discussion}

The Munsell value (V) of clean, fine sand was sensitive to the percent fines added, resulting in rapid decreases in brightness. As shown in figure 3-5, for each mud type the sediment mixtures darkened rapidly between $2 \%$ and $25 \%$. The darkening effect of additional fines beyond $25 \%$ is minimal, as Munsell values at this concentration are close to those at $100 \%$ fines. For example, the Munsell value of the VS mixture at 25\% fines was 4-3, compared to 4.2 at $100 \%$ fines. Similarly, the Munsell value for the MS mixture at $25 \%$ fines was 3.3 , compared to a value of 2.7 at $100 \%$ fines. 
Figure 3-4. Color evolution of pure quartz sand with increasing percent fines derived from two different sources, Vicksburg silt (A) and Mississippi River mud (B).

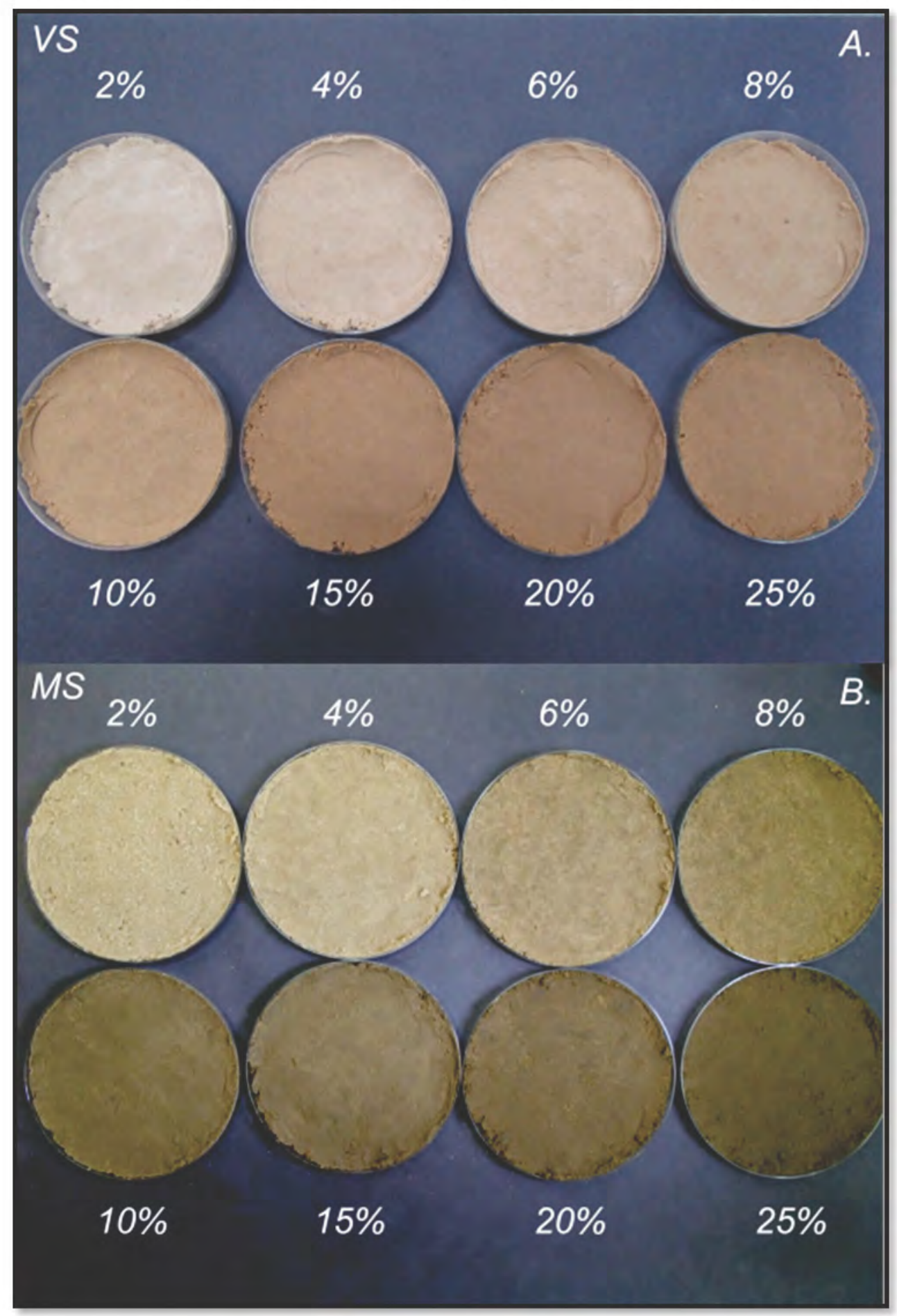

Initial evaluations of this darkening trend suggested either logarithmic, exponential, or power law behavior within the limited domain (figure 3-5). 
Figure 3-5. Measured changes in Munsell value for two sediment mixtures, quartz sand with added Vicksburg silt (blue), and quartz sand with added Mississippi River mud (yellow). Dashed lines indicate probable evolution of Munsell value to respective end-member states at $100 \%$ fines content.

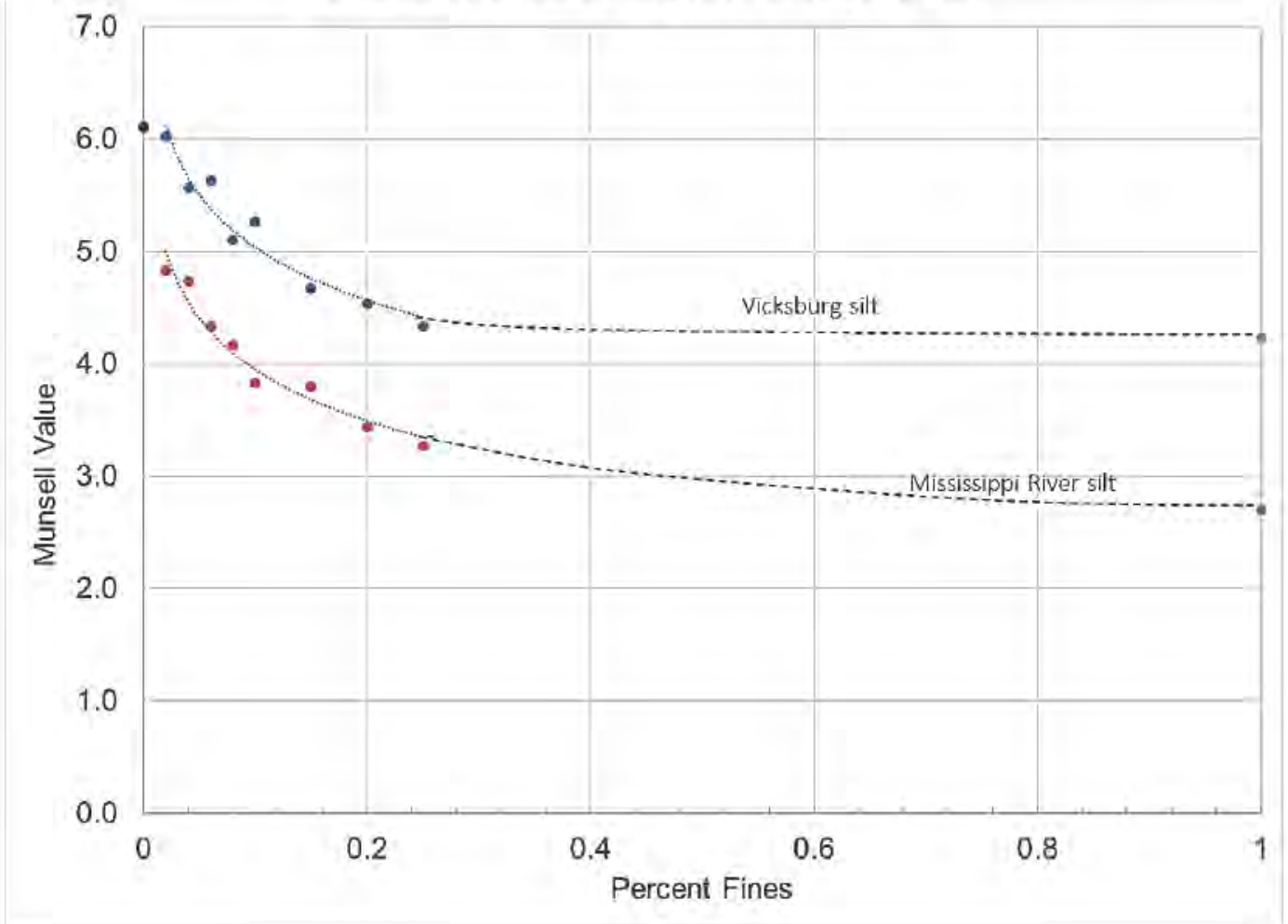

From this initial analysis, the evolution of Munsell values was modeled as a function of percent fines using an exponential decay function. A function of this type can be written as

$$
y(x)=A e^{(-k x)}+C
$$

where the parameters $A, C$, and $k$ are to be determined. The behavior of the function is such that the dependent variable either grows or decays exponentially and asymptotically at a rate set by $k$ between the bounds of $C$ and $A$; the parameters can be thought of as the offset (from the origin) and amplitude, respectively. This behavior is appropriate in modeling the data, since the Munsell value of a mixture must evolve between the two endmember states of $100 \%$ sand and $100 \%$ mud determined by $A$ and $C$. In this case, the equation can be rewritten as 


$$
\hat{V}(f)=\left\{\begin{array}{r}
\left(V_{1}+\left(V_{0}-V_{1}\right) e^{(-k f)}, \quad 0<f<1\right. \\
V_{1}, \quad f=1 \\
V_{0}, \quad f=0
\end{array}\right.
$$

where $\hat{V}$ is the predicted Munsell value, $f$ is the fraction of fines by mass, $V_{1}$ is the Munsell value for $f=1.0$ and $V_{o}$ is the Munsell value for $f=0$.

Here, the parameters for the model fit were determined using the method of nonlinear least squares. The data with fitted curves and 95\% prediction bands are presented in figure 3-6.

Each fit had an $\mathrm{r}^{2}$ value of 0.96 , which indicates that the model well explained the experiment data $(\mathrm{N}=9)$. The model error was estimated using the root-mean-square-error (RMSE) and mean absolute error (MAE), which were 0.12 and 0.10 for VS and 0.17 and 0.13 for MS, respectively. The model parameters are provided in table $3-4$.

The models were then used to determine the added percent fines required to reduce the Munsell value to a threshold of 5.0, the compliance threshold for sand color on nourished beaches. This threshold fraction of fines was predicted at $12 \%$ for VS, whereas only $3 \%$ of MS was predicted to reduce the sand brightness to the same threshold, owing to its much darker color.

Table 3-4. Summary of fitted model parameters and associated confidence limits derived from laboratory experiment.

\begin{tabular}{|c|c|c|c|c|c|c|c|c|c|}
\hline Sample & $k$ & A & C & $\begin{array}{l}K_{L} \\
(95 \%)\end{array}$ & $\begin{array}{l}\text { ku } \\
(95 \%)\end{array}$ & $\begin{array}{l}A_{L} \\
(0.95)\end{array}$ & $\begin{array}{l}A u \\
(0.95)\end{array}$ & $\begin{array}{l}C_{L} \\
(95 \%)\end{array}$ & $\begin{array}{l}C_{u} \\
(95 \%)\end{array}$ \\
\hline VS & 5.14 & 2.54 & 3.60 & -0.85 & 11.14 & 0.98 & 4.10 & 1.91 & 5.30 \\
\hline MS & 16.46 & 2.51 & 3.38 & 7.85 & 25.06 & 1.98 & 3.04 & 2.97 & 3.79 \\
\hline
\end{tabular}

These experiments showed that $\mathrm{V}$ has a strong dependency on the fines content and should evolve asymptotically toward the $100 \%$ fines endmember. Additionally, the rates at which $\mathrm{V}$ evolved, and the saturation limit (defined as the percent fines where $\mathrm{V}$ no longer changes significantly), were different between the two mixtures. A proposed definition of the saturation limit could be the fraction of fines whereby $\mathrm{V}$ is $25 \%$ greater than $\mathrm{V}$ at $f=1$. 
One controlling mechanism of the saturation limit could be the porosity of the sediment relative to the amount of fines in the mixture. One might expect that saturation approaches a maximum as the percentage of fines approaches the porosity of the material. While this may be the case in general, it does not explain the observed differences between the two test mixtures, since the sand used in both mixtures were equivalent. In the context of this study, the rate constant and the magnitude of $\mathrm{V}$ between the two end-members appear to control the saturation limit. For example, from the definition above, the saturation limit for VS mixture is $f=0.21$, while for the MS mixture it is $f=0.11$. As suggested by the experiment results, these factors are likely responsible for the sensitivity of sediment to lightness shifts with fines content. Additionally, there may exist a functional relationship between $k$ and $A$. Section 4.2.7 explores this possibility further. 
Figure 3-6. Observed and modeled changes in Munsell value as a function of the fines fraction by mass. The end-member Munsell value (where $f=1.0$ ) for each mud type is indicated by the dashed lines at Munsell value $=4.2$ and 2.7. The dashed line at Munsell value $=\mathbf{5 . 0}$ indicates the threshold Munsell value commonly used in beach nourishment regulations (most notably FL). The threshold value is reached at $f$ $=0.11$ in the Vicksburg silt case (VS) and $f=0.03$ using Mississippi river mud (MS).

Also shown are the $95 \%$ prediction bands of the model fit.

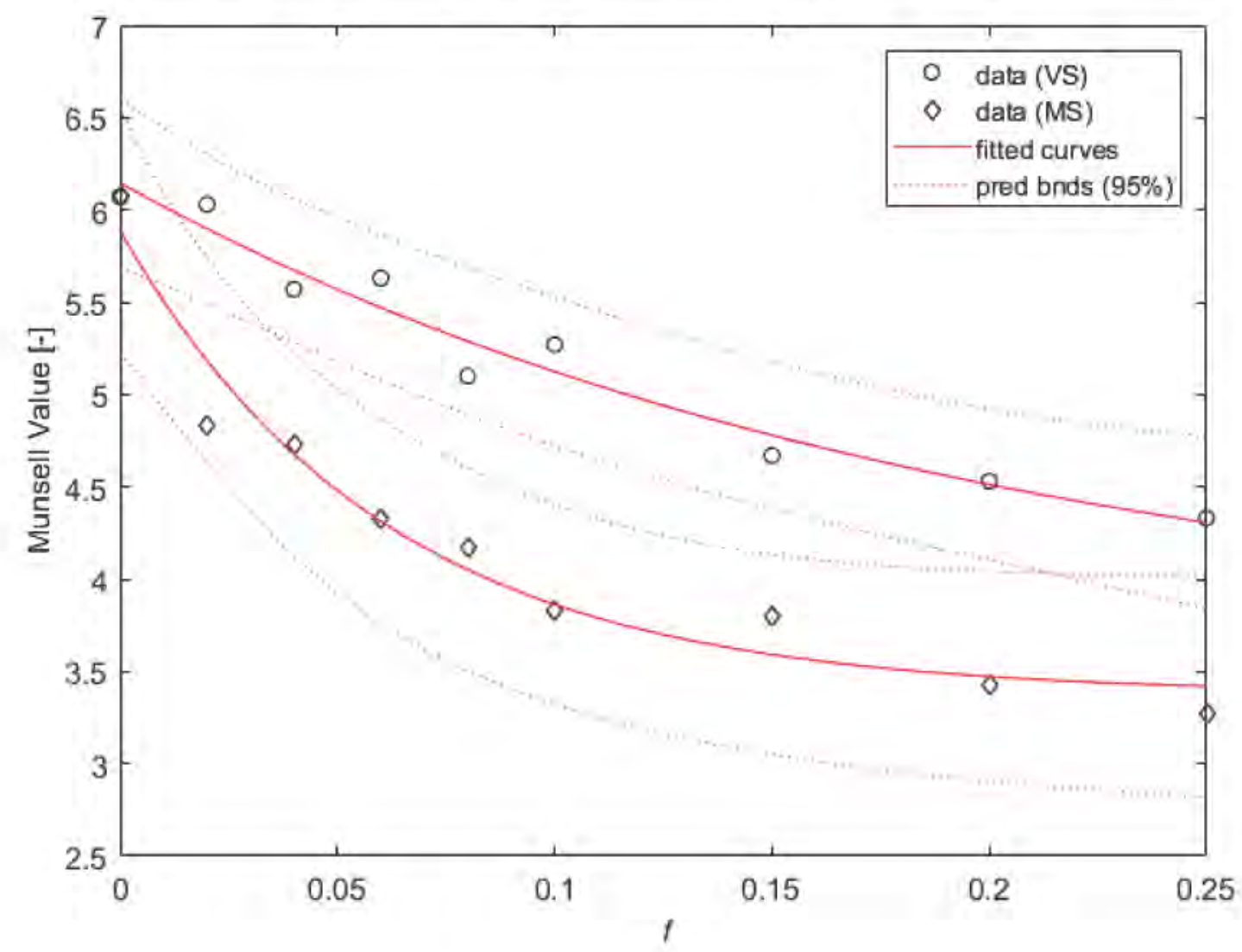

\subsubsection{Comparison with field data}

This effort leverages two beach nourishment projects from two geographic locations, both of which seek to quantify the loss of mud (fines) content through hopper dredging between the borrow area and beach placement site. It is generally known that fine sediments tend to be lost in the dredging and placement process, especially in the overflow period during hopper filling. Additionally, fine-grained sediment is often inherently dark colored. Therefore, these sediments were used to establish functional relationships between the fines content and Munsell value and compare those results to that derived from the laboratory work. 


\subsubsection{Sampling locations}

Sediment samples were collected from the Galveston, Texas, seawall beach nourishment project (2015-2016) and the Ship Island barrier restoration project off the coast of Mississippi (2018). Researchers from the USACE Galveston District collected the data from the former (unpublished), while researchers from ERDC's Coastal and Hydraulics Laboratory collected the latter.

\subsubsection{Methods}

For each location, researchers collected samples at various points in the dredging and placement process on dredges owned and operated by Great Lakes Dredge and Dock Company. Galveston samples were collected aboard the dredge Terrapin Island, where researchers collected samples from the inflow and overflow. Ship Island samples were collected aboard the dredge Liberty Island, and include samples from the inflow, hopper, and beach following placement. At each sampling point (inflow, hopper, beach), researchers composited individual samples to obtain a physical average for the entire load and sampled a total of 11 loads. The fines content for each sample was measured in triplicate for statistical analysis. Researchers also collected beach samples in Galveston but did not include those samples in the analysis because they had insignificant amounts of fines; data points in the Galveston data set totaled 35.

For each data set, the percent fines by mass were determined from composited samples by either sieve analysis or laser diffraction. The percent fines for the Galveston samples were determined using a Malvern Mastersizer 2000, whereas the Ship Island samples were wet sieved at 1/2 phi intervals. The fines are defined here as the fraction of silt and clay finer than $0.063 \mathrm{~mm}$.

\subsubsection{Results and discussion}

Figure 3-7 displays the results of the data analysis. Similar to the laboratory experiment, Munsell value decreases as a function of mud content, though with more scatter. Fitting equation (1) to the data again shows a similar exponential trend compared to the laboratory data (see figure 3-6). 
Figure 3-7. Measured Munsell values of dredged sediments taken in the field as a function of percent fines. Galveston samples were obtained from the hopper dredge Terrapin Island inflow and overflow (unpublished data courtesy of Coraggio Maglio, USACE Galveston District). Ship Island samples were obtained aboard the dredge Liberty Island taken at the inflow, hopper, and postplacement beach locations. Although there is much scatter in both datasets, the trends of the relationships are similar to that of the laboratory data.
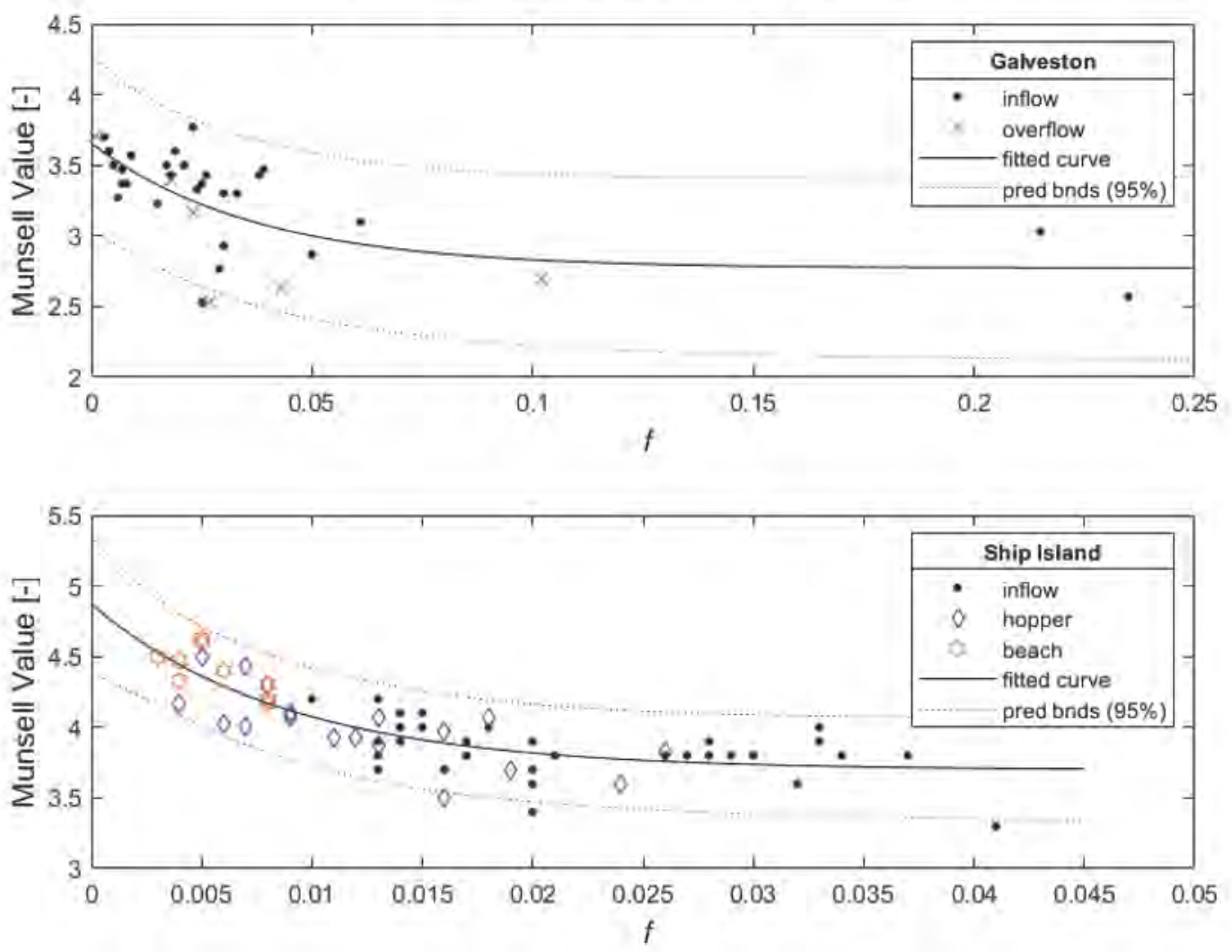

Table 3-5, Summary of fitted model parameters and $95 \%$ confidence limits derived from field data.

\begin{tabular}{|l|l|l|l|l|l|l|l|l|l|}
\hline $\begin{array}{l}\text { Location } \\
\text { ID }\end{array}$ & $\mathrm{k}$ & $\mathrm{A}$ & $\mathrm{C}$ & $\begin{array}{l}\mathrm{K}_{\mathrm{L}} \\
(\mathbf{9 5 \% )}\end{array}$ & $\begin{array}{l}\mathrm{k}_{u} \\
(\mathbf{9 5 \% )}\end{array}$ & $\begin{array}{l}\mathrm{A}_{\mathrm{L}} \\
(\mathbf{0 . 9 5 )}\end{array}$ & $\begin{array}{l}\mathrm{A}_{u} \\
(\mathbf{0 . 9 5 )}\end{array}$ & $\begin{array}{l}\mathrm{C}_{\mathrm{L}} \\
(\mathbf{9 5 \% )}\end{array}$ & $\begin{array}{l}\mathrm{C}_{u} \\
(\mathbf{9 5 \%})\end{array}$ \\
\hline Gal & 26.99 & 0.88 & 2.77 & 2.66 & 51.32 & 0.52 & 0.25 & 2.47 & 3.08 \\
\hline SI & 113.8 & 1.17 & 3.70 & 54.91 & 172.8 & 0.88 & 1.47 & 3.57 & 3.83 \\
\hline
\end{tabular}

The trend of the Galveston data set becomes asymptotic as the fines content approaches $25 \%$, which approximates the behavior of the trends from the laboratory experiment (figure $3-6$ ). Similarly, the rate of change in Munsell value is greatest between $0 \%$ and $10 \%$ fines. The parameter $C$ in table 3-5 implies that the Munsell value of the fines $(f=1.0)$ is approximately 2.8. In contrast, the expected Munsell value when no fines are present ( $f=0$; or, the sum of $A$ and $C$ parameters) is 3.7 , which is the highest 
(moist) Munsell value that can be expected without further alteration to the sediment.

The trend of the Ship Island data set behaves in a similar way, although within a restricted range of fines. The modeled Munsell value evolves from $4.9(f=0)$ to $3.7(f=1.0)$, which very closely approximates measured values. The initial, measured Munsell value of Ship Island sediment, after removal of fines, averaged 4.8 , while the $100 \%$ fines end-member (derived from collected mud within the hopper) was measured at 3.7. However, the curve appears to become asymptotic as $f$ approaches 0.05, which would imply that the Ship Island sediment cannot darken much beyond $5 \%$ fines. This behavior is in contrast to that of the laboratory experiments, which found that saturation of the Munsell value occurred closer to $25 \%$ or beyond. Since the maximum fraction of fines ( O.05) is much less than the pore volume of the sand $(\sim 0.30-0.40)$, the Ship Island sediment would be expected to darken further with increased fines.

As mentioned in section 3.2.3, there may exist a functional relationship between the rate constant $k$ and the parameter $A=\left(V_{0}-V_{1}\right)$. Figure 3-8 and figure 3-9 illustrate the sensitivity of the model to varying $k$ and $A$, respectively. Figure $3-8$ shows that the saturation limit is achieved more quickly for (absolute) increasing values of $k$, while figure 3-9 shows the evolution of Munsell value between $\operatorname{different} f=1$ end-members, in which case the saturation limit is nearly constant between these states. What controls the rate constant is not certain, but it is reasonable to think that darker fines result in greater values of $k$, as is generally the case by examining table 3-4 and table 3-5. However, there are not enough data to draw a definitive conclusion. 
Figure 3-8. Sensitivity of rate constant to equation (1) while holding parameters $A$ and $C$ constant.

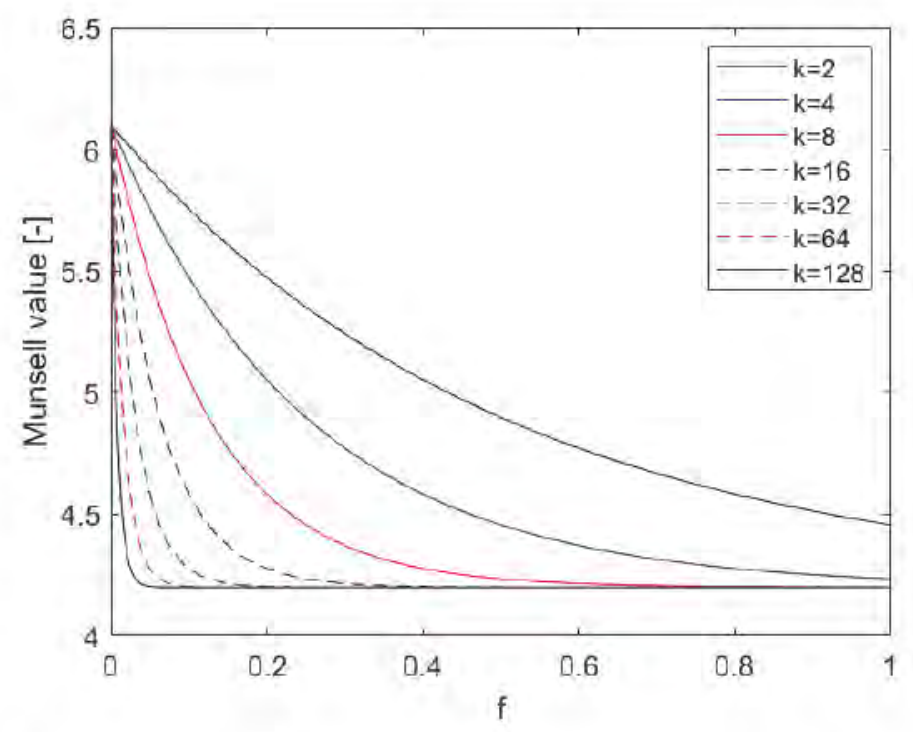

Figure 3-9. Sensitivity of equation (1) to parameter $\boldsymbol{A}=\left(\boldsymbol{V}_{0}-V_{1}\right)$ while holding $k$ and $C$ constant.

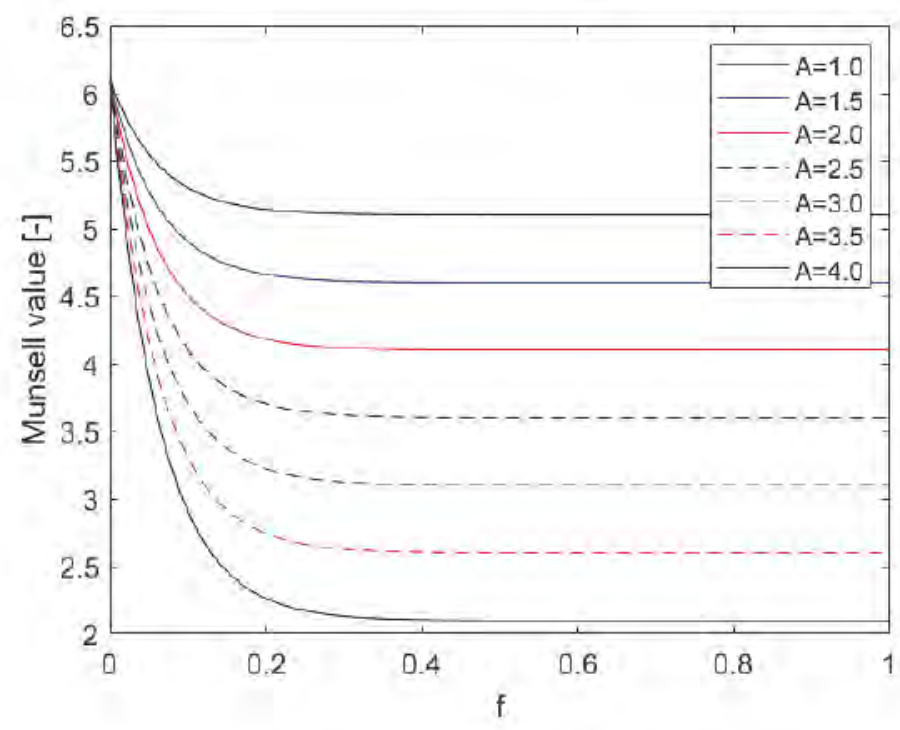

\subsubsection{Method to predict Munsell value change from field samples}

This section provides an example of estimating potential shifts in Munsell value on the basis of expected loss of fines. The example uses sediment collected from a prospective borrow area during the initial scoping phase. Samples returned to the laboratory are composited and wet sieved to separate the fines fraction from the sand fraction. Referring to equations ( 1 ) and (2), the parameters $A$ and $C$ can be found by measuring the sediment 
color (using a digital colorimeter) of composited samples before and after removal of the fines; $k$ is to be determined. Once the Munsell value and percent fines are determined, equation (1) can be solved for the rate constant $k$. The model can then be used to estimate Munsell value shifts for other similar borrow sites with a greater fraction of fines. The procedure is as follows:

1. Collect multiple samples from the potential borrow area and return to the laboratory for processing. Although grab samples may work, obtaining cored samples prevents loss of fines upon retrieval and allows taking samples from the expected dredging cut depth.

2. Analyze samples individually or composited to obtain a physical average. Ensure enough material is available to obtain a sufficient quantity of fines for color measurement.

3. Obtain and record color measurements of moist sediment samples prior to removal of the fines.

4. Separate and record the fines fraction by washing through a no. 200 sieve. The rinse water must be captured to collect the fines. Set the rinse water aside and allow the fines to settle. Decant, then transfer to a container for oven drying. Dry the sand fraction samples. Determine the fraction of fines by the dry mass lost from the initial sample.

5. Obtain and record moist color measurements of the sand fraction (without fines) $\left(V_{0}\right)$ and the fines retained from washing $\left(V_{1}\right)$. Keep sediment moist but not saturated (visibly wet reflection surface). Determine the rate constant using these three data points. For example, table 3-6 provides hypothetical data points below.

Table 3-6. Hypothetical data to derive rate constant for equation (1).

\begin{tabular}{|l|l|c|}
\hline$f$ & Munsell value (measured) & Parameter \\
\hline 0 & $5.5 \pm 0.2$ & $V_{0}$ \\
\hline 0.053 & $4.2 \pm 0.015$ & $\widehat{V}$ \\
\hline 1 & 3.5 & $V_{1}$ \\
\hline
\end{tabular}

6. The parameter $A$ is given as $\left(V_{0}-V_{1}\right), C=V_{1}$, and $\hat{V}$ is the measured Munsell value at the fraction of fines $f$ determined from step 3 .

7. Solve equation (1) for $k$ using,

$$
k=-\ln \left(\frac{\hat{V}-C}{A}\right) / f(\hat{V})
$$


Alternatively, curve fitting techniques in software such as Matlab and Excel (using Solver) can determine the parameters and would allow for automation of larger data sets. A plot of of the data in table 3-6 is presented in figure 3-10.

Figure 3-10. Modeled data from four hypothetical field samples shown as averages with sample variability (the data point at $f=1$ is a single, composited sample obtained from all retained fines).

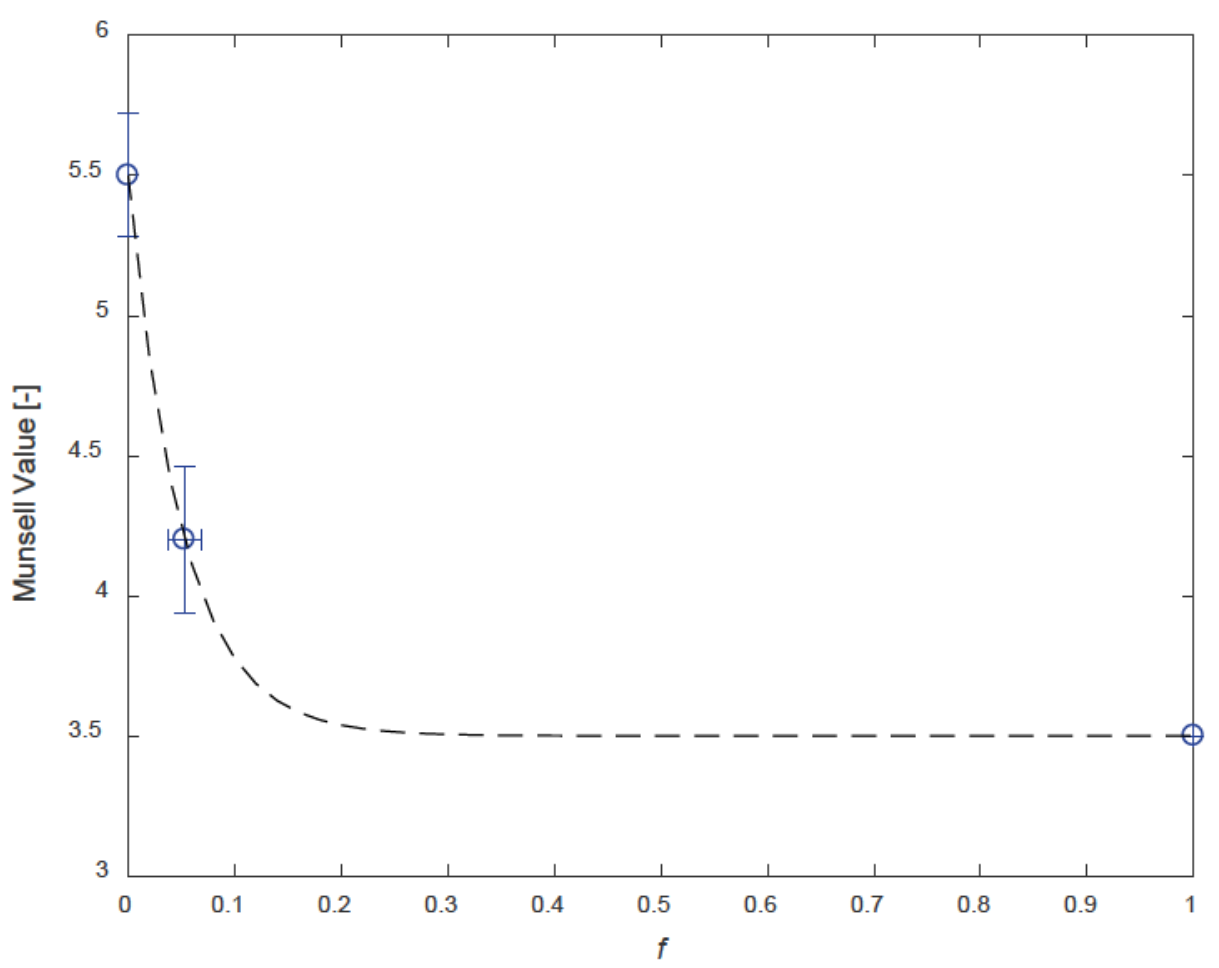

Equation (1) can now estimate brightness shifts on the basis of expected loss of fines. Coor and Ousley (2017) reviewed sediment data from historical dredging records and found that the loss of fine sediment between the borrow area and beach placement site was on the order of $75 \%$ (for in-situ fines content averaging 3.5\%). Similar results were found from a detailed field study by Smith et al. (2019). They found that the percentage fines reduced from an average of $4 \%$ at the borrow site to roughly $0.5 \%$ at the beach. Coor and Ousley (2017) postulate that resource managers could conservatively use a loss rate of $50 \%$. However, caution is warranted, since detailed field studies are limited, especially for borrow areas with fines exceeding $5 \%$ (a typical threshold colloquially known as Florida's "Sand Rule"). Nonetheless, the ability to predict sediment brightness shifts from 
loss of fine sediments will become a valuable component of beneficial use project scoping tools as more field data become available.

\subsection{Munsell value changes due to mixing and sediment dispersion}

This experiment simulated the mixing of brighter, native beach sand with darker, dredged sediments. The experiment examines brightness shifts according to the dispersion of dredged material with native material under a homogeneous mixing scenario.

\subsubsection{Materials}

The sediments used in this experiment were QS, as described previously, and dredged material from Ventura Harbor, California (VH). The VH sand is classified as a moderately well-sorted, medium-fine sand with a $d_{50}=$ $300 \mu \mathrm{m}$. According to XRD results, it is composed of $35 \%$ quartz, $64 \%$ feldspar, and $1 \%$ carbonate materials. In the dry state, the VH sand has a Munsell value of about 5.5, while in the moist state it is about 3.8 , which is significantly darker than the threshold Munsell value of 5 .

\subsubsection{Methods}

Approximately $50 \mathrm{~g}$ of $\mathrm{VH}$ sand was mixed with increasing proportions of QS (dry Munsell value $=8.0$, moist Munsell value $=6.1$ ). The proportions of QS added increased from $5 \%$ to $65 \%$ in $5 \%$ increments by mass. The sediments were thoroughly mixed, placed in a petri dish, and photographed, after which color measurements were taken at three locations; reported color results are based on the averages.

\subsubsection{Results and discussion}

Increasing the proportion of fine sand to the mixture resulted in a total shift of Munsell value from 3.9 to 4.9 (figure 3-11). As well, chroma increased slightly from 1.8 to 2.o. The brightening effect can be attributed to dispersion of the darker materials within the mixture as the amount of QS is increased. As before, the evolution of Munsell value must be confined between the parent materials of the mixture. However, unlike the behavior from the experiment in Section 4.3, the change in Munsell value was linear instead of exponential (figure 3-12). 
Figure 3-11. Photograph comparing Ventura Harbor, California, dredge sediment before (left) and after (right) adding $65 \%$ by mass of clean, fine sand. The Munsell value of the $100 \%$ fine sand was $6.1(\mathrm{H}: 1.6 \mathrm{Y}, \mathrm{V}: 3.9, \mathrm{C}: 1.8)$, while that of the dredged sediment was $3.9(\mathrm{H}: 1.0 \mathrm{Y}, \mathrm{V}: 4.9, \mathrm{C}: 2.0)$.
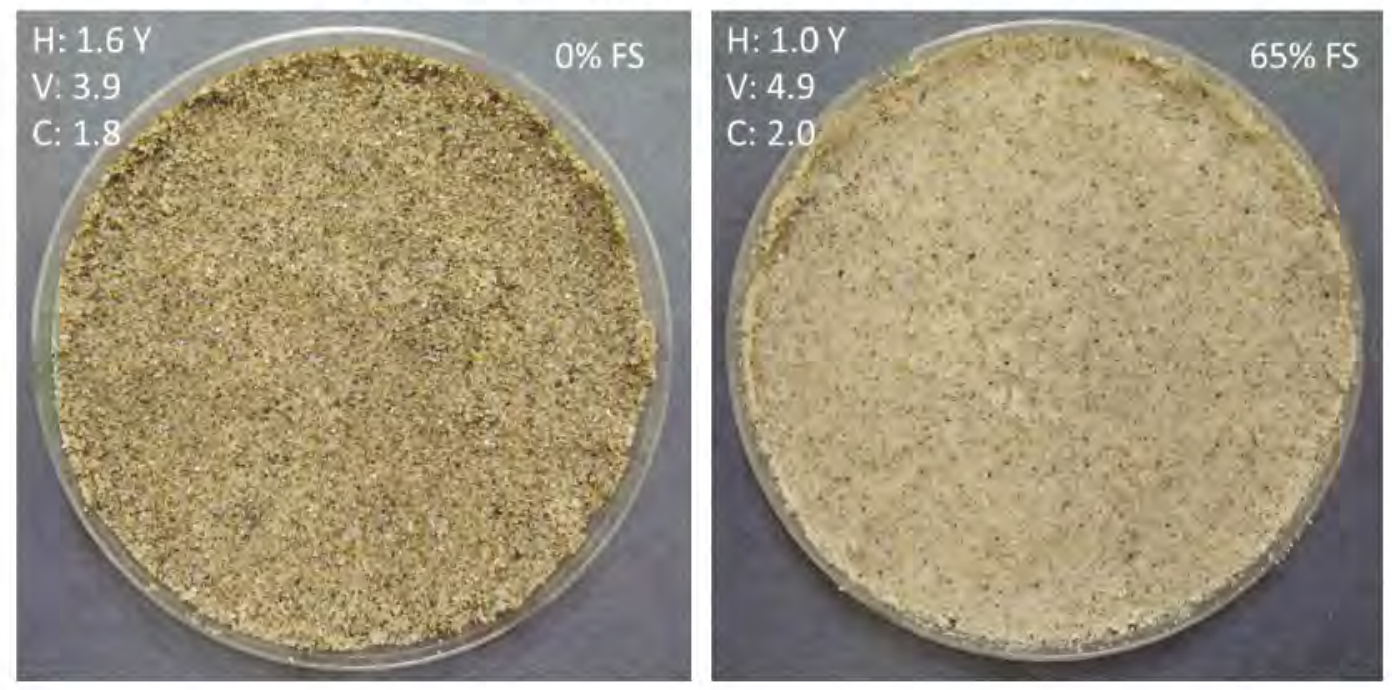

Forecasting the regression equation to $V=5.0$, the threshold value would have been met at approximately $72 \% \mathrm{QS}$ ( $28 \% \mathrm{VH}$ sand). In other words, assuming homogeneous mixing, darker dredged materials may have limited impact on overall brightness (but not hue) if the fill material were limited to about $30 \%$ or less.

In practice, however, the design template of the nourishment volume is such that fill material is placed directly on top of the beach and its shoreface (figure 3-13). Therefore, the extent of sediment mixing between beach fill and native sediment is likely very limited to when the fill material is initially redistributed (through the use of construction equipment) during the pump-out phase of nourishment (figure 3-144). Although in this scenario, winnowing and transport of fine sediments from pump-out operations may have a larger impact on sediment color shifts than mixing processes for the subaerial beach. 
Figure 3-12. Evolution of Munsell value as a function of mixing clean, bright sand with darker, dredged material (Ventura Harbor sediment, Munsell value $=3.8$ ). Here, the VH sediment is essentially being dispersed with proxy native material. The line is based on the inset equation $([y(x)=a x+b]$, where $a=1.63$ and $b=3.80 ; R=0.94$.)

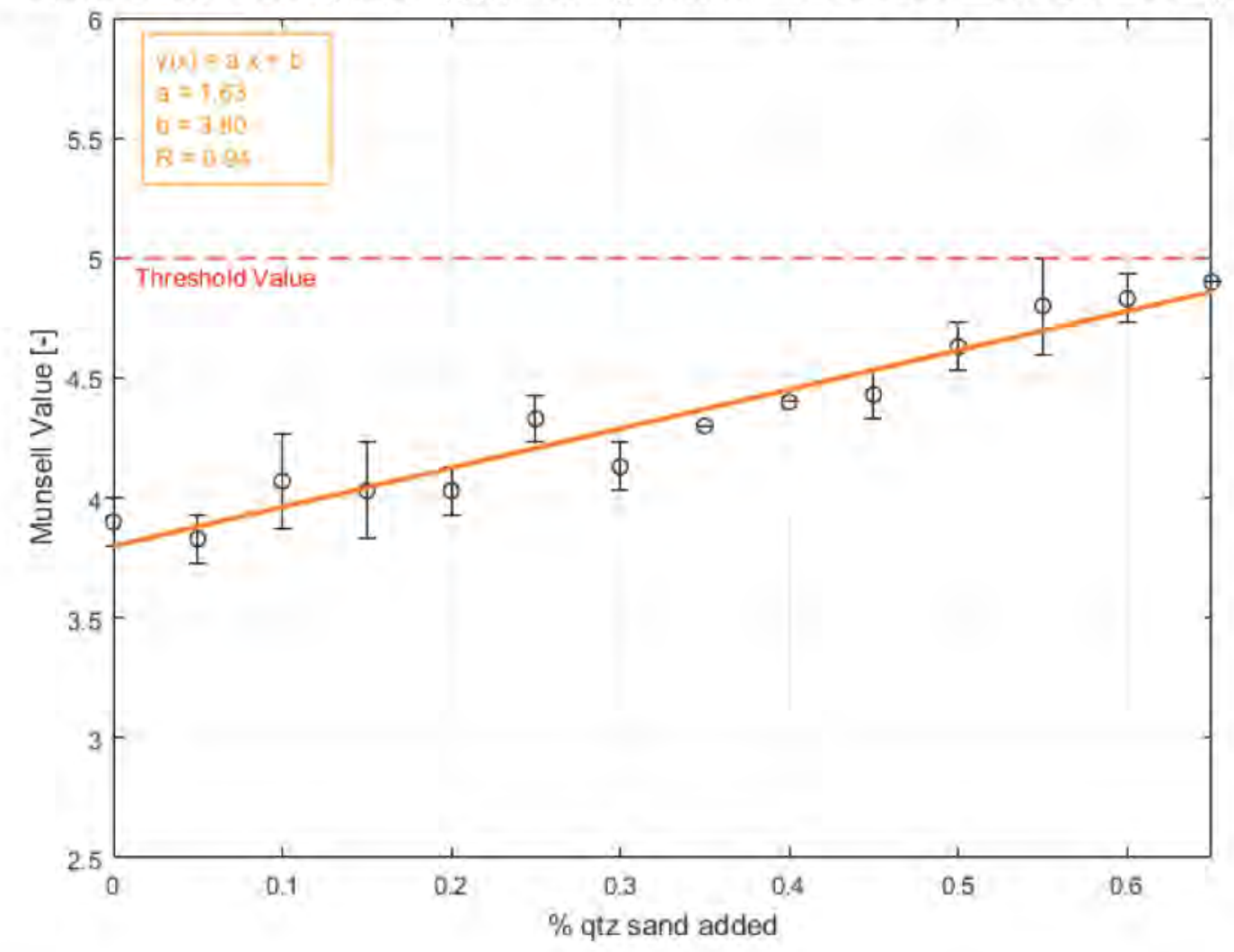

Some vertical mixing may also occur within the intertidal zone of the shoreface where breaking waves occur, but this is not part of the subaerial beach, where aesthetics are most critically evaluated. Perhaps some vertical mixing of the subaerial beach could be attained mechanically through normal foot traffic and periodic grooming activities such as beach raking.

In summary, from these limited data it may be tentatively surmised that exclusion of dark materials from a sediment mixture results in exponential color shifts, while the dispersion of those materials results in linear color shifts. The implication of this result would be that the effect of mixing darker sands with brighter native sediment is not as strong as it is with mixing mud and sand together. 
Figure 3-13. Design schematics of typical nourishment templates (after NRC 1995).

Nourishment of subaerial beach

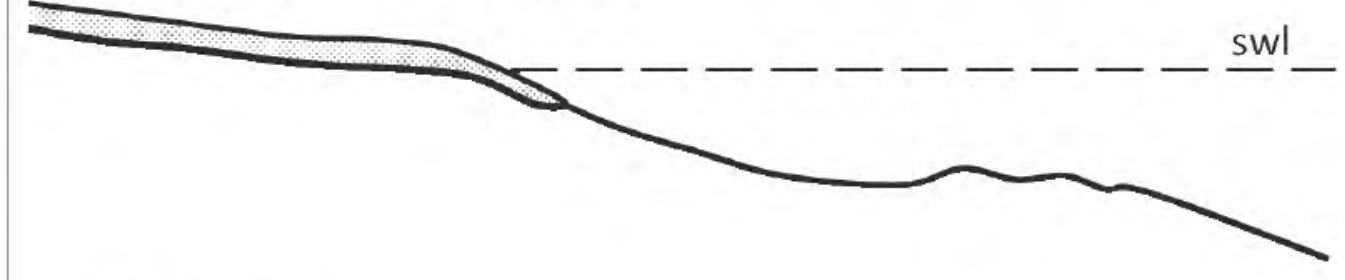

Profile nourishment

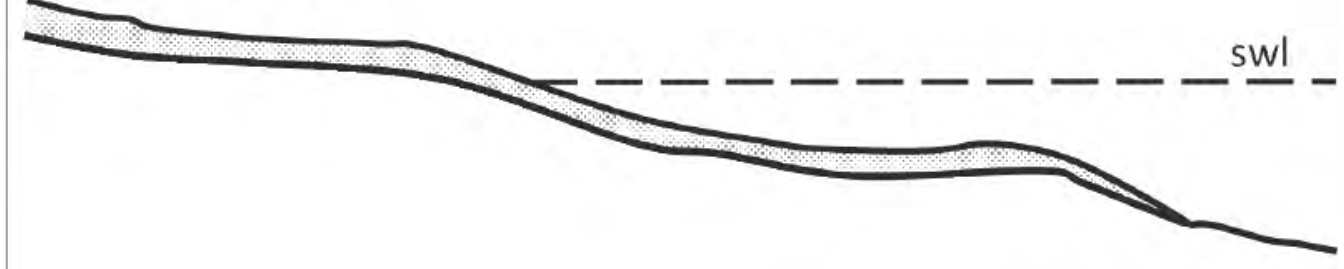

Figure 3-14. Pump-out operations during an active beach nourishment project. Photo courtesy of David Nguyen, ERDC Coastal and Hydraulics Laboratory.

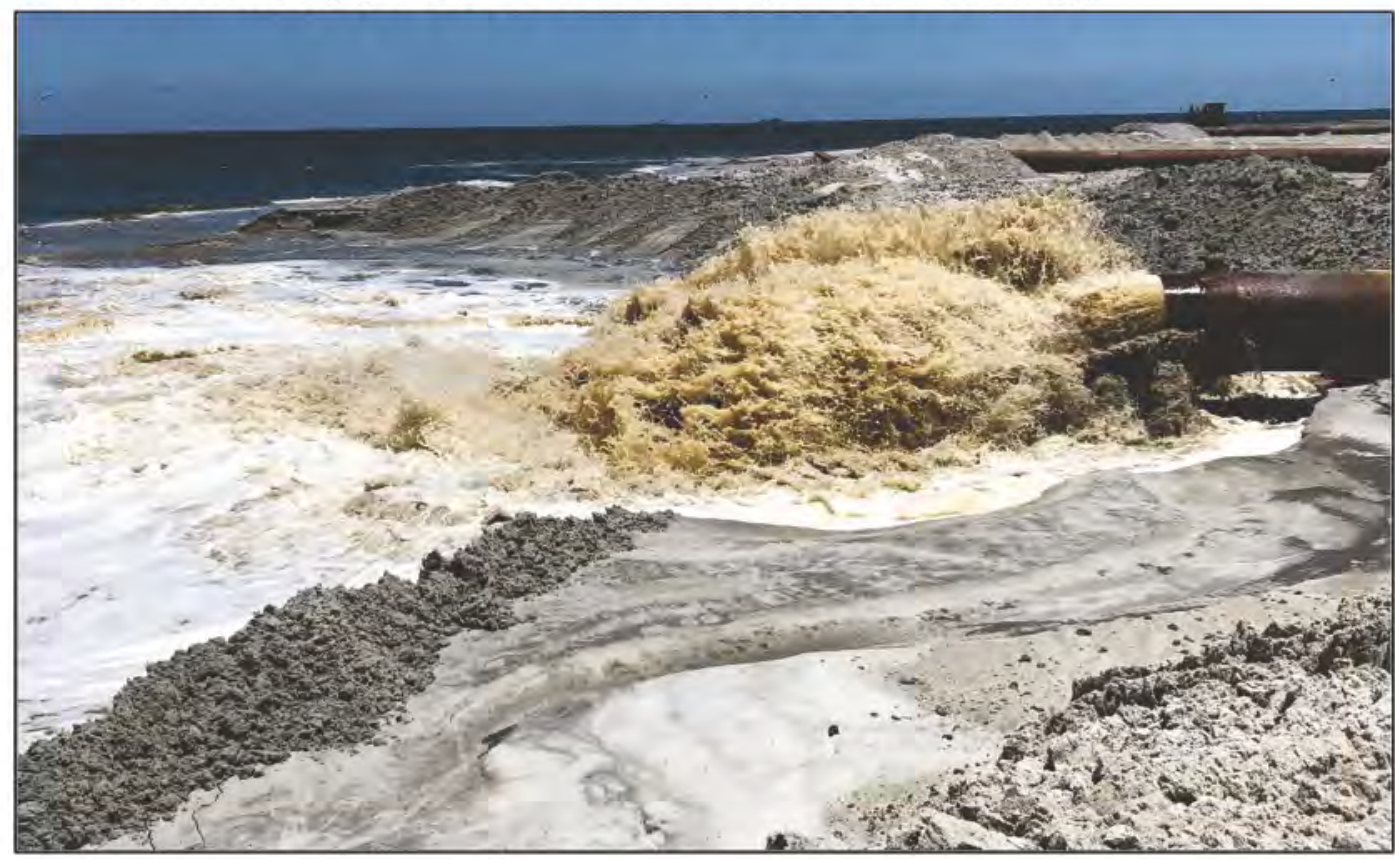

\subsection{Summary and conclusions}

Sediment color is an intrinsic property of parent mineralogy, which can be modified by secondary constituents. A component of sediment color is its relative lightness or darkness, characterized by Munsell value, which is also a function of mineralogy. However, the laboratory experiments in this 
study demonstrated that the relative abundance of fine sediments (mud fraction), coupled with the range of Munsell value between $0 \%$ fines and $100 \%$ fines, exerts significant control over the Munsell value of the bulk sediment.

Munsell value exponentially decreased as a function of increasing percent fines. The change in Munsell value was most rapid between o\% and 25\% fines, becoming asymptotic thereafter. The exponential decrease of Munsell value with fines was confirmed through field data, though the saturation limit (the percentage fines where Munsell value does not significantly change) may vary as a function of sediment size and the Munsell value of the fines contained within. Additionally, the rate at which the Munsell value evolved, and its saturation point (the percent fines where Munsell value no longer changes significantly), may be controlled by the Munsell value of the mud end-member. For example, fines of a darker color have larger Munsell value decay rates and should reach saturation sooner. But if the fines are lighter, the Munsell value decay rate is less and reaches saturation at a greater fines percentage. The color of muds, and their relative brightness or darkness, vary depending on the depositional environment and the mineralogical and chemical makeup of their constituents. For example, lighter colored muds are associated with higher percentages of quartz in the clay-sized fractions. Additionally, the Munsell value of sediments may also change soon after collection because of chemical alteration upon exposure to air. Therefore, confirming these trends requires more data.

Sediment mixing of the subaerial beach may have limited application postnourishment. The loss of fine sediment through the dredging and placement process, because of hydraulic separation of the size classes, produces the greatest color shifts. From that point forward, the Munsell value of the placed sediment will increase (brighten) only through minor mixing processes (mechanical, wind, rain) and subsequent exposure to sunlight. 


\section{Effect of Photolytic Bleaching}

Many studies report color changes resulting from exposure to sunlight using a variety of terms referred to as photolytic bleaching (or bleaching) herein. But few published sources quantify the effects of bleaching. For example, Ballarini et al. (2003) identified bleaching following repeated sun exposure following sediment movement within energetic nearshore environments but did not provide supporting data. A study by the USACE and BOEM (2013) suggested that sediment mixing and solar bleaching will lighten dark sediments, but did not document sediment color change magnitude.

As previously discussed, sediments are known to undergo bleaching in a variety of contexts, little published literature documents the underlying mechanisms, timeframes, and magnitudes associated with photochemically induced sediment color change. Thompson Engineering (2002) attempted to predict potential sediment color changes using a combination of oxidizing agents (hydrogen peroxide), abrasion (rock tumbler), weak acid exposure and an ultraviolet light source. The authors report bleaching occurred within 72 hours but did not differentiate between the mechanisms or document magnitude. It can be expected that some organic matter removal occurred during the chemical oxidation (that is, hydrogen peroxide treatment) as outlined above in the sequential laboratory procedure. The agitation and weak acid dissolution potentially removed sediment grain coatings (including iron oxides). However, limited details about the study conditions (for example, reagent concentrations, light intensity) are provided to quantify the impact of light exposure on color change. In response, a series of laboratory bleaching experiments evaluated color shifts under controlled conditions.

\subsection{Methods}

The eight sediment samples used in secondary color constituent testing (table 3-table 3-1) were exposed to high intensity full spectrum lights in a growth chamber for a period of approximately 25 days to evaluate potential color shifts resulting from photochemical bleaching. Selected light sources (Giesemann Tropic Ultralife $115 \mathrm{~V} / 39 \mathrm{~W} / 6500 \mathrm{~K} / \mathrm{T} 5$ ) were monitored using a Graphtec PetitLOGGER GL10o photometer. Soil colors were 
monitored periodically using the techniques described above, with six replicate measurements taken on each sample at each sample interval (Rabenhorst and Parikh 200o). Statistical differences in sediment color were evaluated using a one-way ANOVA following testing for (ShapiroWilk) and homogeneity of variance (Levene's test) in SPSS version 24.0 (IBM Inc.). In cases where normality could not be achieved the non-parametric Kruskal-Wallis $\mathrm{H}$ test was applied (denoted as $\mathrm{p}^{*}$ ). All significance was evaluated at the $\alpha=0.05$ level and the analysis compared color values at the onset and conclusion of the bleaching experiment.

\subsection{Results and discussion}

The light exposure testing occurred under average luminescence of 54000 $\pm 9200 \mathrm{lux} / \mathrm{hr}$, slightly lower than the reported value occurring at the earth surface at noon during the summer (6500o lux/hr; Thimijan and Heins, 1983). However, because the experimental lights operated throughout the day, an estimate of exposure equivalency can be made. Assuming that lighting occurs at a constant rate of $65000 \mathrm{lux} / \mathrm{hr}$ for 12 hours per day, the current experiment equates to approximately 42 days of natural light exposure. All eight sediment samples examined displayed increases in Munsell value following light exposure, with an average of $0.34 \pm 0.07$ units with color shifts $\geq 0.5$ in a subset of dredged materials (able 5-1). Across all samples, the increase in Munsell value was statistically significant ( $\mathrm{p}=0.001-0.009)$. The increase in Munsell value shifted sediment colors towards the more desirable range (lighter colored materials), and three sediment samples exceeded the Munsell value threshold of 5.0 during the experiment. Additionally, Munsell chroma decreased during the bleaching experiments, with average color changes of $0.16 \pm 0.03$ units and maximum changes of 0.22 units observed. Statistically significant increases in Munsell chroma were observed in the majority of samples ( $\mathrm{p}=$ 0.001-0.021; $\mathrm{p}^{*}=0.046$ ), although two samples (MD1 and FL3) failed to yield significant chroma differences. Figure 5-1 displays a representative example of the color change pattern (sample FL2). Note that the observed color change occurred with approximately 30 days (converted to natural daylight equivalents). Following 30 days the rate of color change (slope of the line) decreased significantly and sample colors stabilized (Munsell value $\mathrm{p}^{*}=0.020 ;$ Munsell chroma $\mathrm{p}=0.013$ ). These findings suggest that the bleaching process may occur fairly quickly following beneficial use placement under high light intensity conditions. 
Although the changes in sediment color due to photolytic bleaching may appear modest ( $\sim 0.5$ and $\sim 0.2$ Munsell value and chroma units respectively), the resultant changes were observable to the human eye. Also, four of the eight samples evaluated displayed in situ colors within $<0.5^{-1}$ color unit of the established regulatory threshold (figures 3.1-3.3), suggesting that small shifts in sediment color have the potential to influence dredged material management decisions. As a result, the observed potential bleaching impacts on color shift may prove significant, especially in conjunction with the effects of mixing and secondary color components.

\begin{tabular}{ccc}
\multicolumn{2}{c}{$\begin{array}{c}\text { Table 5-1. Observed shifts in Munsell value and chroma following exposure to } \\
\text { simulated sunlight. Note that in all samples examined, Munsell value increased } \\
\text { while chroma decreased. This resulted in lighter colored samples considered } \\
\text { more desirable in most beneficial use contexts. }\end{array}$} \\
\hline Sample & Change Munsell value & Change in Munsell chroma \\
\hline FL1 & 0.59 & -0.22 \\
TX1 & 0.34 & -0.15 \\
FL2 & 0.14 & -0.16 \\
CA1 & 0.24 & -0.17 \\
FL3 & 0.14 & -0.11 \\
MD1 & 0.28 & -0.16 \\
PA1 & 0.59 & -0.14 \\
AL1 & 0.22 & -0.14 \\
\hline
\end{tabular}

In general, more bleaching induced color changes occurred in sediments containing a mixture of quartz and carbonates, and preliminary experiments suggested that more color change occurred in samples containing $>75 \%$ quartz (Berkowitz et al. 2018b). However, no clear pattern linking bleaching effects with mineralogy were detected within the available dataset and more investigation is required to link bleaching potential with source material composition. Additional research is also needed to evaluate the influence of variable light sources (both ultraviolet and visible spectra), exposure cycles, and duration with bleaching effects. Future studies should focus on verifying laboratory results under environmentally relevant scenarios to further transition results to a field context. Despite these limitations, data suggests that exposure to simulated sunlight can shift sediment colors toward the desirable range. As a result, bleaching assessment are included in the management framework provided below. 


\subsection{Summary}

Bleaching occurred during the simulated light exposure study, altering sediment color toward the desirable range. Results demonstrate that bleaching is an important process to consider when determining color change potential, although the magnitude of color shifts remained lower than the other factors examined. The paucity of information regarding bleaching induced changes available in literature sources and lack of field studies quantifying bleaching effects remains a challenge. However, the available data allows for incorporation of bleaching effects into a conceptual model of sediment color change potential and supports development of a decision framework to inform project managers.

Figure 4-1. Representative example of photolytic bleaching results (sample FL2) displaying the observed increase in Munsell value (-+-; left axis) and decrease in Munsell chroma ( $\boldsymbol{-}_{\boldsymbol{\Delta}}$; right axis). Note the majority of color change occurred within 30 days beyond which the rate of color change significantly decreases (lines approximate change in slope).

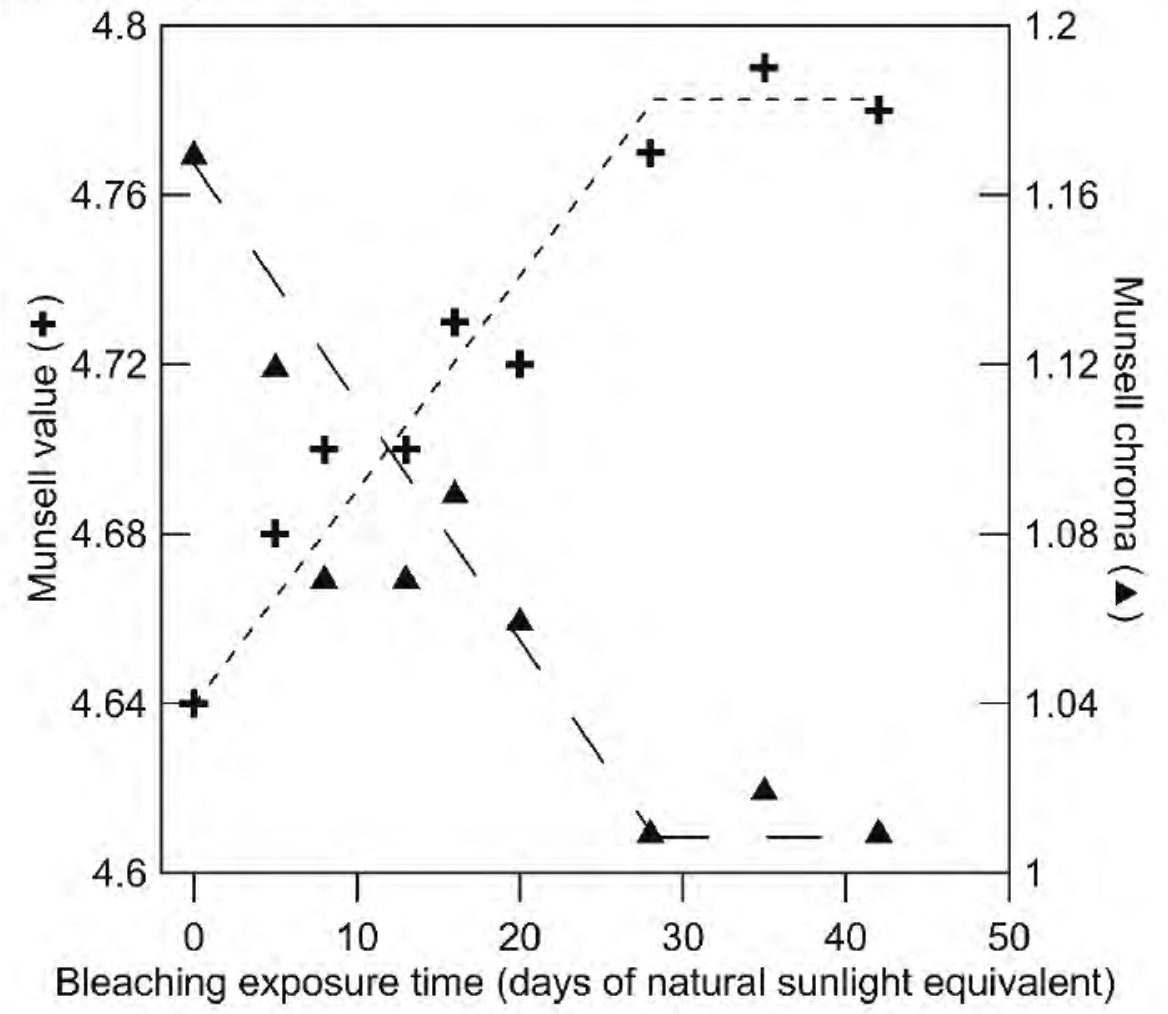




\section{Application of study results}

The study results document color shifts occurring via three pathways including changes in secondary color constituents, mixing, and photolytic bleaching. These pathways allow for development of a conceptual model relating potential sediment color change with underlying mechanisms associated with beneficial use projects (figure 6.1; Berkowitz et al. 2018b). The model incorporates each of the elements described above, weighting the components (by area) according to their potential impact on sediment color change. For example, mixing experiments yielded Munsell value increases of 1-2 units, higher rates than bleaching produced (Munsell value increases of $0.15^{-0.59}$ units). While the degree of color change potential will vary with sediment source and environmental conditions, the model addresses sediment color changes associated with beneficial use projects using a structured and repeatable methodology. Further, the factors influencing color change do not operate independently, but likely interact and result in synergistic effects. For example, if dark materials are removed or diluted during dredging and sediment application (physical processes related to mixing), less organic matter oxidation (related to secondary color constituents) would be required to achieve desirable color end states. This conceptual model can be refined based upon additional research as practitioner's transition to field-scale testing and project implementation. The model also provides weighting factors for the development of quantitative and semiquantitative tools to implement study results as part of the dredged material management process. 
Figure 5-1. Conceptual model of sediment color change potential for beneficial use applications. The model identified the mechanisms by which sediment change can occur in a dredged material management context. Components are weighted (by area) according to the relative magnitude of observed color changes. Adapted from Berkowitz et al. (2018b).

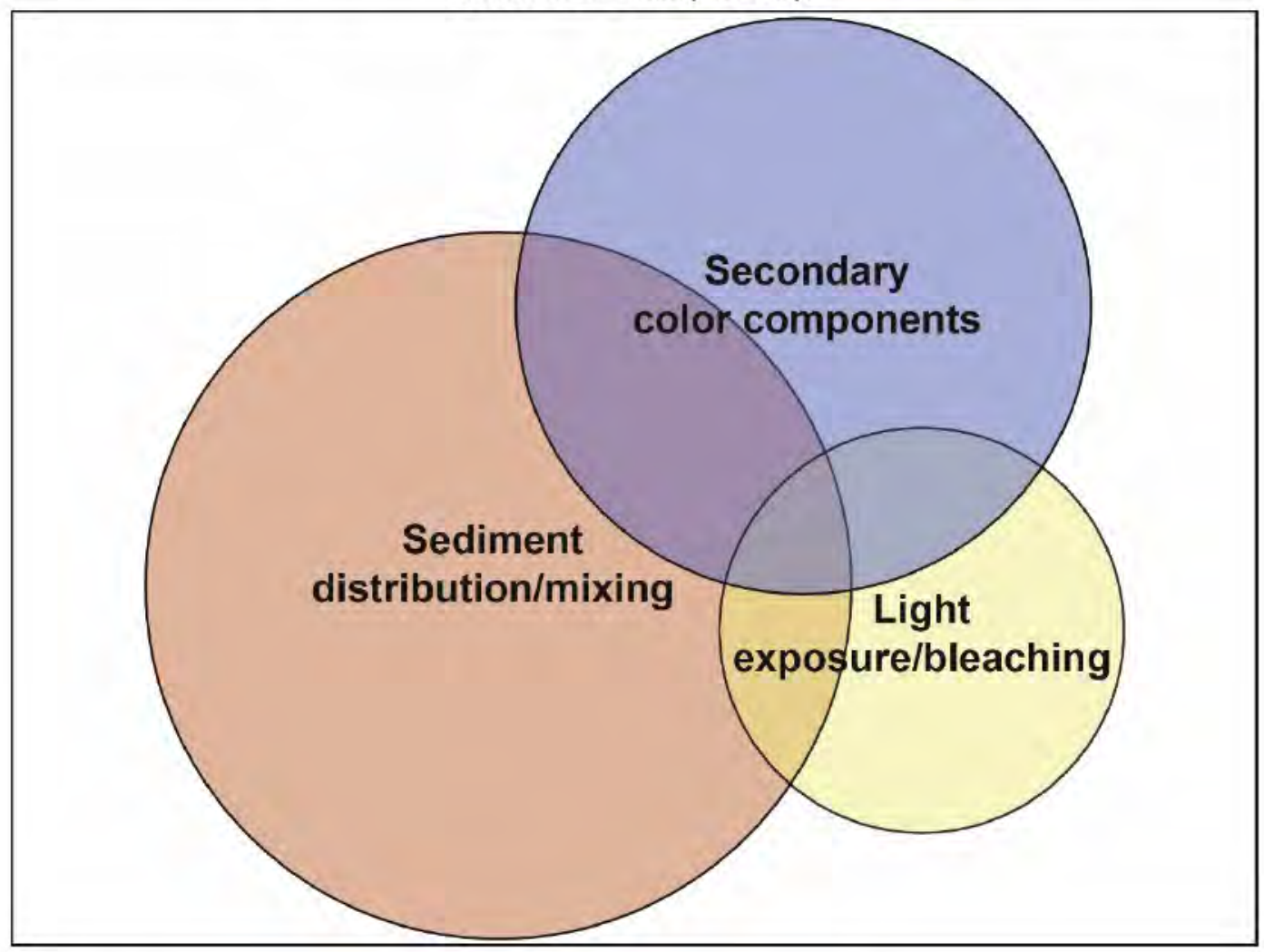

\subsection{Quantitative color change potential protocol}

In general, color change potentials were observed at magnitudes of 1-2, 1.0, and 0.5 Munsell value units during mixing, secondary color treatment, and bleaching studies, respectively. Similarly, results suggest changes in Munsell chroma occurred at magnitudes of 0.2-1.0 units. As a result, in situ sediments within $\leq 2$ Munsell value units and $\leq 1$ Munsell chroma units may be suitable for beneficial use applications if testing results yield substantial color shifts toward the desirable range. The sections above outline specific procedures for determining color change components related to mixing, secondary color constituents and photolytic bleaching. Figure 6.2 summarizes the protocol for determining sediment color change potential, allowing users to conduct sediment testing investigations related to color change. If sufficient color shifts are observed during testing, dredged sediments are likely acceptable for beneficial application. 
As designed, the sediment testing approach examines color change components independently under the rationale that if one or more factors achieve the desired color shift, the sediments are likely acceptable for beneficial use. For example, if mixing experiments demonstrate sufficient color change to surpass established color thresholds, subsequent changes resulting from bleaching and/or secondary color constituents may further enhance color change potential. Managers may provide additional supporting documentation of color change propensity if multiple mechanisms (mixing plus bleaching) result in significant color shifts. In other words, investigating multiple factors provides more confidence that color change is likely to occur under real world conditions.

Once the assessment of color change potential has been completed, practitioners should consider environmental factors at sediment placement locations. For example, more mixing is expected in higher energy environments exposed to foot or vehicle traffic, high winds, and wave action compared to low energy areas. Bleaching effects may be decreased in low solar energy locations with short days and less intense sunlight compared with high rates of incident light, long summers and frequent clear skies. Similarly, more organic matter removal will occur in hotter environments with ample oxygen to fuel microbial decomposition. These environmental factors in conjunction with the color change capacity testing results must be considered when evaluating sediment color change dynamics during project planning and implementation.

As stated elsewhere field testing is recommended where practicable to verify testing results. Additional research can further inform future implementation of these study results, especially as field testing occurs. However, to date the current protocols represent the most rigorous scientific analysis of sediment color change potential available in a beneficial use context. As a result, resource management agencies are encouraged to apply the testing approach. In particular, the protocol may prove useful when sediment colors are close to established threshold values. 
Figure 5-2. Quantitative protocol for determining sediment color change potential. Note that the specific instructions for conducting each evaluation are provided in sections 3-5 of this report.

\begin{tabular}{|c|c|c|}
\hline $\begin{array}{c}\text { SECONDARY } \\
\text { COLOR COMPONENTS }\end{array}$ & $\begin{array}{l}\text { SEDIMENT } \\
\text { MIXING }\end{array}$ & $\begin{array}{l}\text { SEDIMENT } \\
\text { BLEACHING }\end{array}$ \\
\hline $\begin{array}{l}\text { - Collect dredged samples } \\
\text { - Dry and weigh samples } \\
\text { - Chemical \& instrumentation } \\
\text { - Determine baseline color }\end{array}$ & $\begin{array}{l}\text { - Collect dredged and target } \\
\text { placement location samples } \\
\text { - Dry and weigh samples } \\
\text { - Determine baseline color }\end{array}$ & $\begin{array}{l}\text { - Collect dredged samples } \\
\text { - Dry and weigh samples } \\
\text { - Acquire lights, photometers, etc } \\
\text { - Determine baseline color }\end{array}$ \\
\hline $\begin{array}{l}\text { - Remove carbonate coatings } \\
\text { using acetate } \\
\text { - Determine sediment color }\end{array}$ & $\begin{array}{l}\text { - Mix } 1-2 \% \text { dredged sediments } \\
\text { with target location materials } \\
\text { - Determine sediment color }\end{array}$ & $\begin{array}{l}\text { - Expose sediment to lights for } \\
\text { 1-7 days } \\
\text { - Determine sediment color }\end{array}$ \\
\hline $\begin{array}{l}\text { - Remove organic matter } \\
\text { coatings using oxidizing agent } \\
\text { - Determine sediment color } \\
\text { - Remove amorphous Fe-oxide }\end{array}$ & $\begin{array}{l}\text { Sequentially add } 2-5 \% \\
\text { increments of target location } \\
\text { sediments } \\
\text { - Determine sediment color at } \\
\text { each interval }\end{array}$ & $\begin{array}{l}\text { - Continue exposure at } 1-2 \text { week } \\
\text { intervals } \\
\text { - Determine sediment color at } \\
\text { each interval }\end{array}$ \\
\hline $\begin{array}{l}\text { Coatings using reducing agent } \\
\text { Determine sediment color }\end{array}$ & $\begin{array}{l}\text { Repeat the procedure above, } \\
\text { ading incremental amounts of } \\
\text { native materials to the dredged } \\
\text { sediments }\end{array}$ & $\begin{array}{l}\text { - Continue exposure and } \\
\text { measurements until color } \\
\text { sediment color stabilizes } \\
\text { ( } 4-6 \text { weeks) } \\
\text { - Determine sediment color at } \\
\text { each interval }\end{array}$ \\
\hline $\begin{array}{l}\text { - Analyze material color change } \\
\text { capacity } \\
\text { - Conduct field verification } \\
\text { (where possible) } \\
\text { - Apply assessment results }\end{array}$ & $\begin{array}{l}\text { capacity } \\
\text { Conduct field verification } \\
\text { (where possible) } \\
\text { - Apply assessment results }\end{array}$ & $\begin{array}{l}\text { - Analyze material color change } \\
\text { capacity } \\
\text { - Conduct field verification } \\
\text { (where possible) } \\
\text { - Apply assessment results }\end{array}$ \\
\hline
\end{tabular}

In some cases, the protocol outlined above may prove impracticable due to project schedule requirements, available budget, and staff expertise. Also, the procedure requires specialized equipment, training, and chemicals. In response, a semiquantitative framework has been developed to assist in decision making when limited data is available. The approach makes basic assumptions about the relative magnitude of color shifts associated with secondary color components, bleaching and mixing effects. Based upon the data presented in the current report, mixing experiments resulted in the highest degree of color change, followed by secondary components (approximately 50\% of mixing effect) and bleaching (approximately $25 \%$ of mixing effect). These proportions and associated environmental conditions have been synthesized into a simple empirical equation to interpolate between color change mechanisms, yielding an index of sediment color change propensity.

The index uses a series of flow charts to determine high (green), moderate (yellow) and low (red) levels of expected color change based upon both sediment characteristics and environmental conditions (figure 6-3-6-5). 
For example, mixing effects within a project area result from a combination of source material sediment color, placement location sediment color, and the degree of mixing forcing (high energy vs. low energy environments). If source material sediment color is close to placement location sediment color (within 1 Munsell value and chroma unit) and a high energy environment is present to support mixing, the material will likely exceed color threshold requirements (figure 6-4). If the material is not close to the color threshold, or placement occurs in low energy environments with limited mixing potential, then the source materials may not be appropriate for beneficial use from a sediment color perspective. Similar frameworks are provided for secondary color component and bleaching mechanisms. While these approaches do require some measurements (organic matter removal; measurement of dredged sediment and placement location colors), the degree of data collection required is significantly reduced from the fully quantitative approach described in sections $3-5$.

In order to convert the three individual color change components into a single index, flow chart results are assigned numerical values for each factor with green equating to 2.0, yellow equating to 1.o, and red equating to o.o. Each factor is then weighted by its relative impact on color change potential by applying the following empirical equation:

Dredged sediment color change propensity index (DSCCPI) =

$$
\frac{(4 * \text { mixing effect })+(2 * \text { secondary component effect })+(\text { bleaching effect })}{14}
$$

The resultant DSCCPI provides an index of color change potential according to the three color change mechanisms coupled with environmental conditions. The index ranges from o.o when sediment color change remains unlikely to 1.0 when a high degree of color change is anticipated. Operationally, a DSCCPI of $\geq 0.57$ is recommended when potential sediment color change is limiting beneficial use applications. However, as noted elsewhere limited data exists on the application of DSCCPI values under field scenarios. As a result the index should only be applied when other factors (particle size) are acceptable for beneficial use applications and sediment color compatibility remains the limiting factor. Specifically, the DSCCPI should not be used to prevent beneficial use application of materials that otherwise meet placement requirements but represents a 
tool to evaluate sediment near (but outside of) established color threshold requirements.

By design, this semiquantitative approach integrates multiple drivers of sediment color change along with environmental conditions, promoting a repeatable decision support tool for evaluating dredged material color change. Note that the semiquantitative approach requires some data collection, including determining sediment color and the removal of organic matter coatings via oxidation. However, these techniques should be available to most practitioners. Note that the environmental conditions include determinations of high and low energy environments as well as high and low light intensity locations. These factors are not explicitly defined here, as they vary by geographic location, season, and with beneficial use materials and technique. For example, beneficial use activities occurring prior to stormy, high wind periods may experience additional mixing than during other times of the year. Further, dredged sediments placed in near shore environments may be exposed to more mixing action, but less light than approaches that place materials directly on the beach surface. As a result, determinations of mixing energy and light intensity must be considered on a project by project basis. However, these determinations can be further operationally defined as DSCCPI applications become more numerous. 
Figure 5-3. Flow chart for determining semiquantitative dredges sediment color change potential of secondary color components.

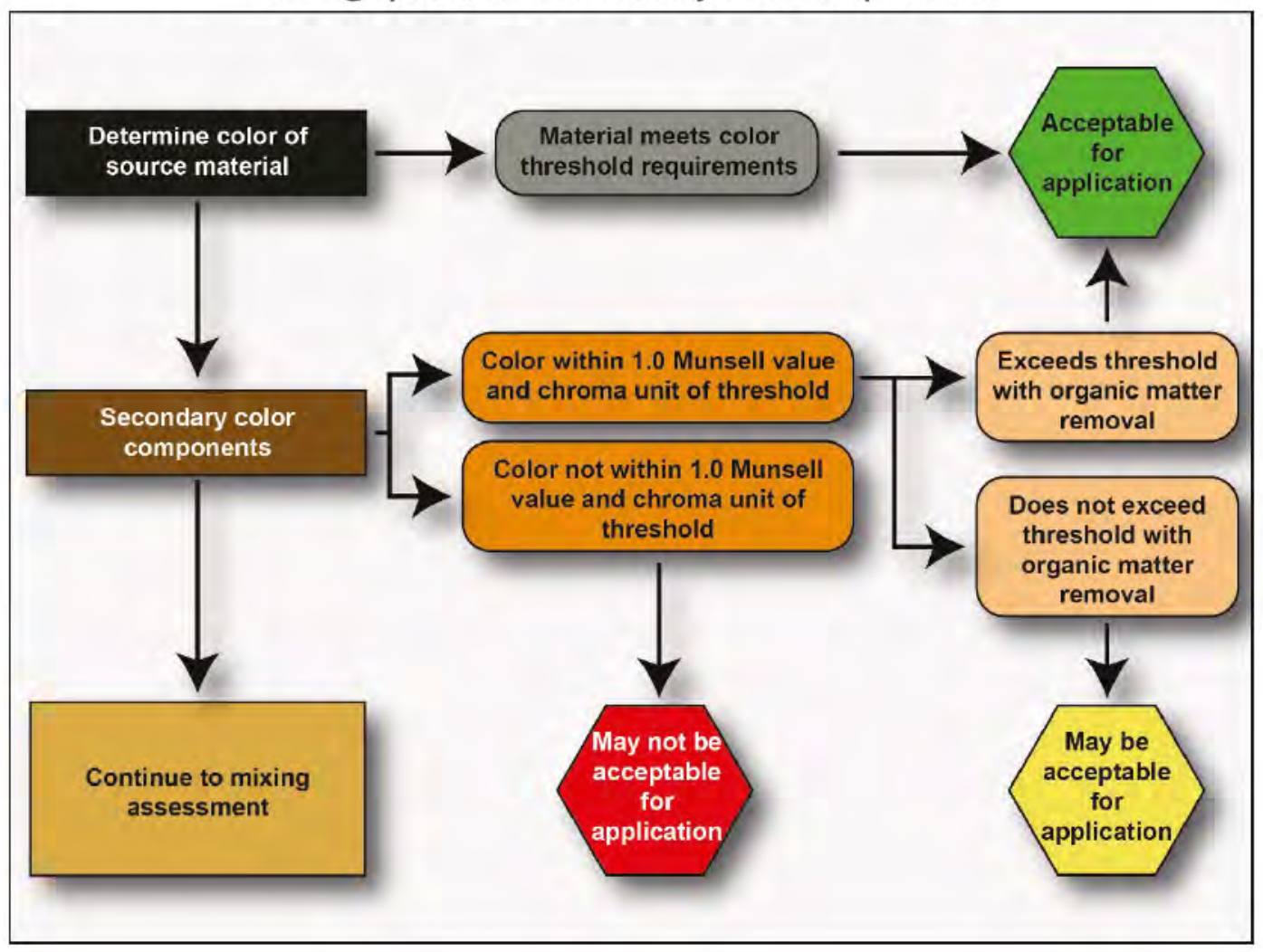


Figure 5-4. Flow chart for determining semiquantitative dredges sediment color change potential of mixing assessment.

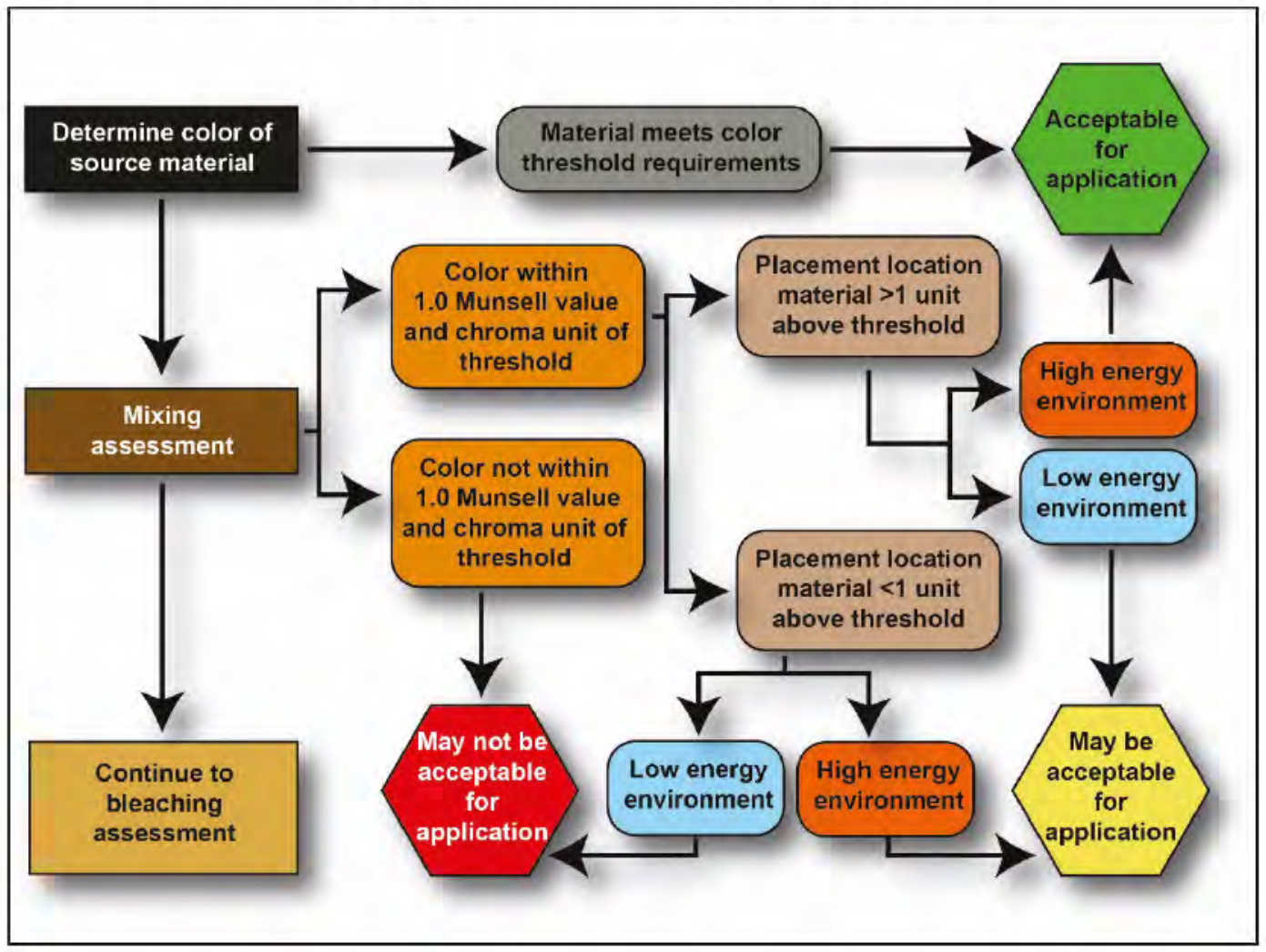


Figure 5-5. Flow chart for determining semiquantitative dredges sediment color change potential of bleaching assessment. An example of synthesis of the three data components is also provided to aid in application of the DSCCPI.

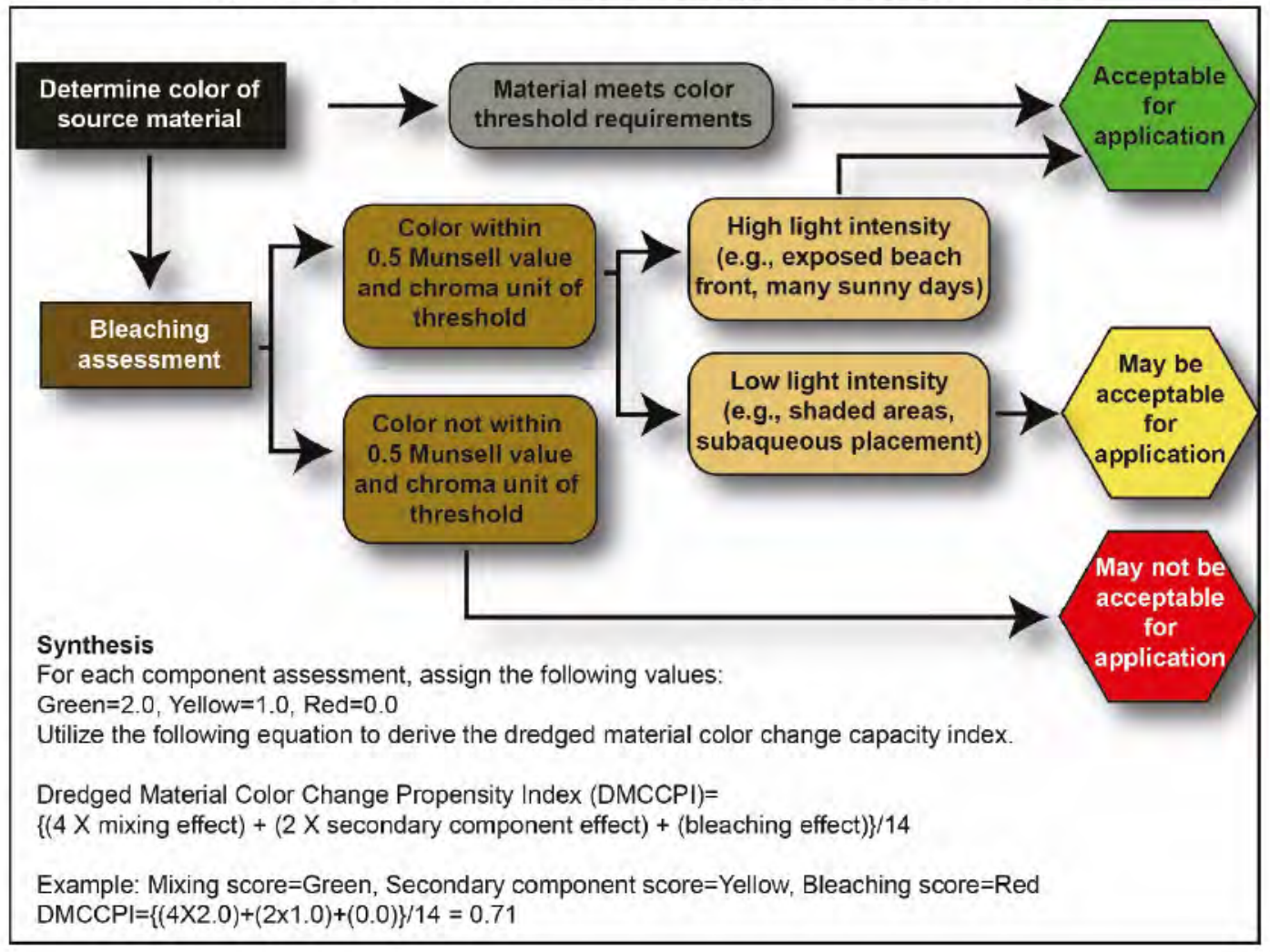




\section{Summary}

Dredged materials colors can limit beneficial use activities based on color compatibility requirements and concerns related to habitat and/or aesthetics. In response, dredged sediment color change potential was quantified across an array of geographic locations and geologic origins. Results indicate that three factors related to bleaching, secondary color components (that is, organic matter) and mixing drive color change potential. Potential color shifts can be predicted using the laboratory protocols outlined herein, allowing users to predict color change in a beneficial use context. Additionally, a semiquantitative index of color change propensity is introduced to synthesize color change potential and environmental conditions. The quantitative protocol and semiquantitative index provide resource managers with tools to evaluate dredged sediment color changes based upon the best available information. Results of this work may be improved on with future research and field testing; however, this report represents the most comprehensive assessment of dredged material color change potential evaluated for beneficial use applications. 


\section{References}

Ackerman, R.A.; Rimkus T., and Horton R., 1992. "Hydric and thermal characteristics of natural and renourished sea turtle nesting beaches along the Atlantic coast of Florida." Tallahassee, Florida: Florida Department of Natural Resources.

Andrews, J.T., and Freeman, W. 1996. "The Measurement of Sediment color using the colortron spectrophotometer." Arctic and Alpine Research 28(4), 524-528.

Ballarini, M. Wallinga, J, Murray, A.S., Van Heteren, S., Oost, A.P., Bos, A.J.J., and Van Eijk, C.W.E., 2003. "Optical dating of young coastal dunes on a decadal time scale." Quaternary Science Reviews 22(10), 1011-1017.

Berkowitz, Jacob F., Christine M. VanZomeren, and Anthony M. Priestas, 2018. "Potential color change dynamics of beneficial use sediments." Journal of Coastal Research 34(5), 1149-1156.

Berkowitz, J.F, Vanzomeren, C.M, Priestas, A. 2018b. "Investigating sediment color change dynamics to promote beneficial use applications." Proceedings: Western Dredging Association, Dredging Summit and Expo. June 25-29, 2018. Norfolk, VA.

Blott, S.J. and Pye, K. 2001. "GRADISTAT: A grain size distribution and statistics package for the analysis of unconsolidated sediments." Earth Surface Processes and Landforms 26(11), 1237-1248.

California Coastal Commission (CCC). 2010. Addendum to Item Th 6c (CD-035-10) on the August 12, 2010, Commission Agenda. San Francisco, CA: State of California, National Resources Agency.

California Geological Survey (CGS). 2005. "Assessment of offshore sand resources for potential use in restoration of beaches in California." CGS/MMS Cooperative Agreement Number 1435-01-03-CA-73201. Sacramento, CA: GCS.

Canfield, D.E. 1993. "Organic matter oxidation in marine sediments." In: Makenzie FT. and Chou, L. (eds.), Interactions of $C, N, P$ and $S$ biogeochemical Cycles and Global Change. Berlin: Springer, pp. 333-363.

Crain, D.A., Bolten, A.B., and Bjorndal, K.A., 1995. "Effects of beach nourishment on sea turtles: Review and Research Initiatives." Restoration Ecology 3(2) 95-104.

Coor, Jennifer L., and Jase D. Ousley. 2020. Historical Analysis of the Change in Percent Fines During Beach Nourishment. PowerPoint Presentation. US Army Corps of Engineers. https://www.fsbpa.com/2020TechPresentations/Coor.pdf.

Dean, R.G., 2003. Beach nourishment: Theory and Practice, 18. World Scientific Publishing Company.

Deaton, B.C., and Balsam, W.L. 1991. "Visible spectroscopy--a rapid method for determining hematite and goethite concentration in geological materials." Journal of Sedimentary Research 61(4). 
Finkl, C.W. and Walker, H.J., 2005. "Beach nourishment." In: Schwartz, M.L. (ed.), Encyclopedia of Coastal Science. Netherlands: Springer, pp. 147-161.

Florida Department of Environmental Protection (FLDEP). 2010. Design, Siting and Other Requirements. Florida Administrative Code. 62B-41.007.

Florida Department of Environmental Protection (FLDEP). 2012a. Broward County Shore Protection Project - Segment II Broward County, FL Sediment quality control/quality assurance plan. Florida Department of Environmental Protection, Beaches Inlets and Ports Program.

Florida Department of Environmental Protection (FLDEP). 2012b. Sediment quality assurance/quality control plan for beach restoration or nourishment using an offshore borrow site. FDEP File No. 0307741-002-JC. Florida Department of Environmental Protection.

Florida Department of Environmental Protection (FLDEP). 2014. Sediment quality assurance/quality control plan for beach restoration or nourishment using an offshore borrow site. Charlotte County Erosion Control Project. Charlotte County, FL.

Florida Department of Environmental Protection (FLDEP). 2015. Sediment quality control/quality assurance plan -Duval County Beach Nourishment Project. FDEP Permit No. 0228528-005-JC. Florida Department of Environmental Protection.

Frey, A.E., Morang, A., and King, D.B. 2016. "Galveston Island, Texas, Sand Management Strategies.” ERDC/CHL TR-16-13. Vicksburg, MS: Engineer Research and Development Center.

Fuentes, M.M.P.B., Maynard, J.A., Guinea, M., Bell, I.P., Werdell, P.J., and Hamann, M. 2009. "Proxy indicators of sand temperature help project impacts of global warming on sea turtles in Northern Australia." Endangered Species Research 9, $33-40$.

Giosan, L., Flood, R.D., and Aller, R.C. 2002. "Paleoceanographic significance of sediment color on western North Atlantic drifts: I. Origin of color." Marine Geology 189(1), 25-41.

Gravens, M.B., Ebersole, B.A., Walton, T.L., and Wise, R.A. 2008. "Beach fill design." In: Ward, D. (ed.) Coastal Engineering Manual. Washington, DC: US Army Corps of Engineers.

Gretag/Macbeth. 200o. New Windsor, NY: Munsell ${ }^{\circledR}$ color.

Hampton, M.A., Blay, C.T., and Murray, C.J. 2004. "Carbonate sediment deposits on the reef front around Oahu, Hawaii." Marine Georesources and Geotechnology 22(12) $65-102$.

Hanson, H., Brampton, A., Capobianco, M., Dette, H.H., Hamm, L., Laustrup, C., Lechuga, A., and Spanhoff, R. 2002. "Beach nourishment projects, practices, and objectives-a European Overview." Coastal Engineering 47(2) 81-111. 
Hays, G.C., Godley, B.J., and Broderick, A.C. 1999. Long-term thermal conditions on the nesting beaches of green turtles on Ascension Island. Marine Ecology Progress. Series, 185, 297-299.

Hays, G.C., Ashworth, J.S., Barnsley, M.J., Broderick, A.C., Emery, D.R., Godley, B.J., Henwood, A., and Jones, E.L. 2001. The importance of sand albedo for the thermal conditions on sea turtle nesting Beaches. Oikos 93(1), 87-94.

Hulin V., Girondot, M., and Godfrey, M.H. 2007. "Mixed and Uniform Brood Sex Ratio Strategy in Turtles: The Facts, the Theory, and Their Consequences". In: Jeanette, G.W., Godfrey, M.H. and Bels, V. (eds.), Biology of Turtles: From Structures to Strategies of Life. CRC Press.

Johnson, T.D. 2009. Harbor area management plan - reginal general permit technical report. Harbor Resources Division City of Newport Beach. Newport Beach, CA.

Kamrunnahar I., McBratney, A.B., and Singh, B. 2004. "Estimation of soil colour from visible reflectance spectra." Proceedings of SuperSoil 2004: 3rd Australian New Zealand Soils Conference, 5 - 9 December 2004, University of Sydney, Australia.

Kunze, G.W. and Dixon, J.B. 1986. "Pretreatment for Mineralogical Analysis." In: Klute A. (ed.). Methods of Soil Analysis, Part 1. Physical and Mineralogical Methods, 2nd Ed. Madison, WI: American Society of Agronomy, pp. 91-100.

Levene, H. 1960. "Robust tests for equality of variances." In: Olkin, I., Ed. Contributions to Probability and Statistics. Palo Alto: Stanford University Press, 278-292.

LJA Engineering, Inc. 2016. Beach ridge restoration on McFadden National Wildlife Refuge, Jefferson County, TX. Draft Environmental Assessment.

Maglio, C., J. D. Ousley, A. Hershorin, and M. Mora. 2015. "Tampa Harbor Maintenance Dredging with Egmont Key Beneficial Re-use of High Silt Content Material using a Traditional Template versus Cross Shore Swash Zone Placement." Western Dredging Association Conference (WEDA TAMU 2015), Houston, TX.

Martínez-Carreras, N., Udelhoven, T., Krein, A., Gallart, F., Iffly, J.F., Ziebel, J., Hoffmann, L., Pfister, L., and Walling, D.E. 2010. "The use of sediment colour measured by diffuse reflectance spectrometry to determine sediment sources: application to the Attert River Catchment (Luxembourg)". Journal of Hydrology, 382(1), 49-63.

Massachusetts Department of Environmental Protection (MDEP). 2007. "Beach nourishment: MassDEP's guide to best management practices for projects in Massachusetts." Massachusetts Office of Coastal Zone Management. Boston, MA.

Mayer, L.M. 1999. "Extent of coverage of mineral surfaces by organic matter in marine sediments." Geochimica et Cosmochimica Acta 63(2), 207-215.

Mikutta, R., Kleber, M., Kaiser K., and Jahn, R., 2005. “Organic matter removal from soils using hydrogen peroxide, sodium hypochlorite, and disodium peroxodisulfate." Soil Science Society of America Journal 69, 120-135. 
Milton, S.L., Schulman, A.A. and Lutz, P.L. 1997. "The effect of beach nourishment with aragonite versus silicate sand on beach temperature and Loggerhead sea turtle nesting success." Journal of Coastal Research 904-915.

National Research Council. 1995. Beach nourishment and protection. Washington, DC: The National Academies Press. https://doi.org/10.17226/4984.

Nordstrom, K.F., 2005. "Beach nourishment and coastal habitats: research needs for improving compatibility." Restoration Ecology 13, 215-222.

North Carolina Division of Coastal Management (NCDCM). 2013. Technical Standards for Beach Fill Projects. 15A NCAC 07H.0312. Post et al. 1993.

Ousley, J.D., Kromhout, E., Schrader, M.H., Lillycrop, L. 2014. "Southeast Florida sediment assessment and needs determination (SAND) Ssudy" ERDC/CHL TR14-10. Vicksburg, MS: US Army Corps of Engineers.

Pranzini, E., Simonetti, D., and Vitale, G. 2010. "Sand color rating and chromatic compatibility of borrow sediments.” Journal of Coastal Research 798-808.

Rabenhorst M.C. and Parikh, S. 200o. "Propensity of soils to develop redoximorphic color changes." Soil Science Society of America Journal 64, 1904-1910.

Rabenhorst, M.C., Schmehling, A., Thompson, J.A., Hirmas, D.R., Graham, R.C., and Rossi, A.M. 2015. "Reliability of soil color standards." Soil Science Society of America Journal 79(1).

Reddy, K.R., Clark, M.W., DeLaune, R.D., and Konchum, M. 2013. "Physicochemical Characterization of Wetland Soils." In: Reddy, K.R. and Delaune, R.D. (eds.). Methods of biogeochemistry of wetlands. Madison, WI: Soil Science Society of America Press, pp. 41-54.

Schwertmann, U., 1993. "Relations between iron oxides, soil solor, and soil formation." In: Bigham, J.M., Ciolkosz, E.J. (Eds.), Soil Color, 31, 51-69. Soil Science Society of America (SSSA), Madison, WI. SSSA Special Publications.

Shields J.A., Arnaud S.T., Paul E.A., and Clayton J.S. 1966. "Measurement of soil color." Canadian Journal of Soil Science 46, 83-90.

Soil Survey Staff. 1951. Soil Survey Manual. US Department of Agriculture Handbook 18. National Resources Conservation Service. Lincoln, NE: National Soil Survey Center.

Soukup, D.A., B.J. Buck, and W.G. Harris. 2008. "Preparing soils for mineralogical analysis". In A. Ulery and R. Drees (eds.) Methods of soil analysis, Part 5:

Mineralogical Methods. Madison, WI : Soil Science Society of America, pp. 13-31.

Smith, S. J., A. M. Priestas, K. E. Brutsché, and D. B. Bryant. 2019. "Sediment sorting by Hopper Dredging and Placement Operations." In Conference: International Conference on Coastal Sediments. 10.1142/97898112044870245

Stauble, D.K., 1991. "Native beach assessment techniques for beach fill design." Coastal Engineering Technical Note CETN II-29. Vicksburg, MS: Waterways Experiment Station. 
Thimijan, R.W. and Heins, R.D. 1983. "Photometric, radiometric, and quantum light units of measure: a review of procedures for interconversion." HortScience 18(6): 818-822.

Thompson Engineering Staff. 2002. "Sediment bleaching analysis from disposal sites along the Alabama, Black Warrior and Tombigbee River Systems in Alabama." Project 02-2116-0030.

US Army Corps of Engineers (USACE). 1995. "Design Aspects of Corps Beach Nourishment Projects.” Coastal Engineering Technical Note CETN I-61. Vicksburg MS: Waterways Experiment Station,

US Army Corps of Engineers (USACE). 2008. USACE Norfolk District - Regional Permit. CENAO-REG 08-RP-19.

US Army Corps of Engineers (USACE). 2016. Mississippi Coastal Improvements Program (MsCIP): Hancock, Harrison, and Jackson Counties, Mississippi. US Army Corps of Engineers, Mobile District.

US Army Corps of Engineers. 2013. "Sand color change monitoring of Black Warrior Tombigbee Waterway (BWT) sand placed along the shoreline of Eastern Dauphin Island, Alabama." US Army Corps of Engineers, Mobile District.

US Army Corps of Engineers (USACE). 2016. Miami-Dade County 2016 Renourishment Project. USACE Jacksonville District, Jacksonville, FL.

US Army Corps of Engineers (USACE). 2012. "Regional Supplement to the Corps of Engineers Wetland Delineation Manual: Eastern Mountains and Piedmont region (Version 2.o).” ed. J.F. Berkowitz, R. Lichvar, C.V. Noble, J.S. Wakeley. ERDC/EL TR-12-9. Vicksburg, MS: Engineer Research and Development Center.

US Army Corps of Engineers (USACE) and Bureau of Ocean Energy Management (BOEM), 2013. Environmental assessment: Folly Beach Shore Protection and se of Outer Continental Shelf Sand. Draft Report. Charleston County, SC.

Vasilas L.M. and Berkowitz, J.F. 2016. "Identifying hydric soils in the landscape." In M.J. Vepraskas and C.B. Craft (eds.) Wetland Soils: Genesis, Hydrology, Landscapes, and Classification 2nd. Ed. Boca Raton, FL: CRC Press.

Vepraskas, M.J., M. Polizzotto, and S.P. Faulkner. 2015. "Redox chemistry of hydric soils." In M.J. Vepraskas and C.B. Craft (eds.) Wetland Soils: Genesis, Hydrology, Landscapes, and Classification. 2nd. Ed. Boca Raton, FL: CRC Press.

Weber S.B., Broderick A.C., Groothuis T.G., Ellick J., Godley B.J., Blount J.D. 2012. "Fine-scale thermal adaptation in a Green Turtle nesting population." Proceedings of the Royal Society B. 279, 1077-1084.

Williams G.L. 2005. "Sediment compatibility for beach nourishment in North Carolina." Tri-Services Infrastructure Conference, St. Louis, MO. 


\section{Appendix A}

Table A1. Summary table of Munsell color measurements taken on bulk samples in the dry and wet condition.

\begin{tabular}{lllllll}
\hline Sample & Hue & \multicolumn{3}{l}{ Value } & \multicolumn{3}{l}{ Chroma } \\
\hline & Dry & Wet & Dry & Wet & Dry & Wet \\
\hline SK1 & $4.3 Y$ & $6.5 Y$ & 6.1 & 4.6 & 0.8 & 0.8 \\
SK2 & $4.9 Y$ & $6.7 Y$ & 6.1 & 4.5 & 0.8 & 0.8 \\
SK3 & $4.5 Y$ & $6.2 Y$ & 6.2 & 4.6 & 0.8 & 0.9 \\
SK4 & $3.8 Y$ & $4.8 Y$ & 6.8 & 5.0 & 0.8 & 1.0 \\
SK5 & $4.1 Y$ & $6.4 Y$ & 6.3 & 4.5 & 0.9 & 0.8 \\
\hline GS6 & $1.2 Y$ & $1.8 Y$ & 6.0 & 4.1 & 2.1 & 1.8 \\
GS7 & $0.9 Y$ & $1.6 Y$ & 5.9 & 4.1 & 2.0 & 1.7 \\
GS8 & $1.2 Y$ & $1.7 Y$ & 6.1 & 4.3 & 1.8 & 1.8 \\
GS9 & $1.8 Y$ & $2.5 Y$ & 6.1 & 4.1 & 1.9 & 1.6 \\
\hline EK10 & $2.6 Y$ & $4.5 Y$ & 6.4 & 4.4 & 1.0 & 0.9 \\
EK11 & $2.9 Y$ & $4.2 Y$ & 6.4 & 4.7 & 1.1 & 1.1 \\
EK12 & $1.7 Y$ & $3.0 Y$ & 7.7 & 5.5 & 0.8 & 0.9 \\
EK13 & $0.9 Y$ & $1.9 Y$ & 8.2 & 5.9 & 0.9 & 1.0 \\
EK14 & $1.0 Y$ & $2.5 Y$ & 7.6 & 6.1 & 1.1 & 1.1 \\
\hline VH15 & $0.9 Y$ & $1.3 Y$ & 5.6 & 4.0 & 2.1 & 1.8 \\
VH16 & $0.8 Y$ & $1.3 Y$ & 5.5 & 3.8 & 1.9 & 1.8 \\
VH17 & $0.7 Y$ & $1.3 Y$ & 5.7 & 4.0 & 2.1 & 1.8 \\
VH18 & $1.5 Y$ & $2.1 Y$ & 5.5 & 3.7 & 2.2 & 1.8 \\
VH19 & $1.6 Y$ & $2.1 Y$ & 5.5 & 3.8 & 2.0 & 1.8 \\
\hline VH20 & $1.3 Y$ & $9.0 Y$ & 5.7 & 4.7 & 2.2 & 3.0 \\
\hline M21 & $8.6 Y R$ & $9.0 Y R$ & 6.0 & 4.8 & 2.4 & 2.8 \\
M22 & $8.7 Y R$ & $8.9 Y R$ & 6.0 & 4.7 & 2.2 & 2.8 \\
M23 & $8.7 Y R$ & $2.0 Y$ & 6.2 & 4.0 & 2.2 & 1.8 \\
HH24 & $3.7 Y$ & $5.9 Y$ & 4.7 & 3.4 & 1.5 & 1.0 \\
PH30 & $1.7 Y$ & $3.1 Y$ & 6.5 & 4.7 & 1.5 & 1.4 \\
JA33 & $0.3 Y$ & $0.4 Y$ & 6.2 & 4.7 & 3.6 & 3.6 \\
OC36 & $2.2 Y$ & $3.1 Y$ & 6.1 & 4.5 & 1.9 & 1.8 \\
\hline & & & & & & \\
\hline
\end{tabular}


Table A2. Summary table of Munsell color measurements by size class, one sample selected for each location. Missing size classes indicate that not enough material was retained on the sieve to make a reliable color measurement.

\begin{tabular}{|c|c|c|c|c|c|c|c|c|c|}
\hline Sample & $\begin{array}{c}\text { Size } \\
\text { class } \\
\text { (phi) }\end{array}$ & Hue & Value & Chroma & Sample & $\begin{array}{c}\text { Size } \\
\text { class } \\
\text { (phi) }\end{array}$ & Hue & Value & Chroma \\
\hline 1 & -1 & $2.1 Y$ & 2.1 & 11 & 21 & 0 & 8.6YR & 5.9 & 3.2 \\
\hline 1 & 0 & $2.3 Y$ & 5.9 & 11 & 21 & 1 & 8.7YR & 5.8 & 2.6 \\
\hline 1 & 1 & $4.4 Y$ & 5.2 & 0.8 & 21 & 2 & 8.5YR & 5.7 & 2.2 \\
\hline 1 & 2 & $4.5 Y$ & 5.6 & 0.8 & 21 & 3 & 8.9YR & 5.9 & 2.1 \\
\hline 1 & 3 & $3.7 Y$ & 6.5 & 10 & 24 & 2 & $3.7 Y$ & 3.5 & 14 \\
\hline 1 & 4 & $2.5 Y$ & 7.0 & 12 & 24 & 3 & $4.0 \mathrm{Y}$ & 4.3 & 15 \\
\hline 6 & -1 & $0.1 Y$ & 5.4 & 14 & 24 & 4 & $3.9 \mathrm{Y}$ & 4.6 & 16 \\
\hline 6 & 0 & 8.9YR & 5.1 & 14 & 24 & $<4$ & $3.9 \mathrm{Y}$ & 4.1 & 15 \\
\hline 6 & 1 & $9.8 \mathrm{YR}$ & 5.6 & 18 & 27 & 2 & $4.9 \mathrm{Y}$ & 3.9 & 11 \\
\hline 6 & 2 & $1.0 Y$ & 5.4 & 2.0 & 27 & 3 & $4.9 \mathrm{Y}$ & 4.6 & 10 \\
\hline 6 & 3 & $1.6 \mathrm{Y}$ & 5.8 & 2.1 & 27 & 4 & $4.8 Y$ & 4.9 & 10 \\
\hline 6 & 4 & $2.0 Y$ & 5.9 & 19 & 27 & $<4$ & $4.7 Y$ & 5.1 & 12 \\
\hline 10 & -2 & $1.5 Y$ & 5.2 & 10 & 30 & 1 & $19 Y$ & 5.6 & 18 \\
\hline 10 & -1 & $3.1 Y$ & 6.2 & 10 & 30 & 2 & $18 \mathrm{Y}$ & 6.3 & 16 \\
\hline 10 & 0 & $2.0 \mathrm{Y}$ & 5.7 & 11 & 30 & 3 & $2.6 \mathrm{Y}$ & 5.8 & 11 \\
\hline 10 & 1 & $3.3 Y$ & 5.5 & 0.9 & 33 & 1 & $0.3 Y$ & 5.8 & 3.6 \\
\hline 10 & 2 & $3.8 Y$ & 5.5 & 0.8 & 33 & 2 & $0.2 Y$ & 6.2 & 3.8 \\
\hline 10 & 3 & $16 Y$ & 7.5 & 13 & 33 & 3 & $0.8 Y$ & 6.2 & 3.6 \\
\hline 10 & 4 & $16 \mathrm{Y}$ & 7.6 & 12 & 33 & 4 & $13 Y$ & 5.5 & 3.1 \\
\hline 15 & 1 & $1.0 \mathrm{Y}$ & 4.6 & 17 & 36 & 1 & $2.3 Y$ & 5.6 & 2.2 \\
\hline 15 & 2 & $0.5 Y$ & 5.4 & 2.1 & 36 & 2 & $2.6 \mathrm{Y}$ & 5.4 & 17 \\
\hline 15 & 3 & $0.9 Y$ & 5.6 & 2.1 & 36 & 3 & $2.8 Y$ & 5.8 & 16 \\
\hline 18 & 1 & $2.0 Y$ & 4.9 & 17 & 36 & 4 & $3.6 \mathrm{Y}$ & 5.5 & 14 \\
\hline 18 & 2 & $1.2 Y$ & 5.2 & 2.1 & 36 & $<4$ & $3.2 \mathrm{Y}$ & 5.6 & 16 \\
\hline 18 & 3 & $15 Y$ & 5.5 & 2.2 & & & & & \\
\hline 18 & 4 & $2.3 Y$ & 5.2 & 20 & & & & & \\
\hline
\end{tabular}


Table A3. Color measurements of Ventura Harbor, CA dredged material with increasing percentages of clean, fine sand.

\begin{tabular}{lllll}
\hline VH-16+\% FS added & Hue & P. Hue & Value & Chroma \\
\hline $0 \%$ & 1.57 & Y & 3.90 & 1.80 \\
$5 \%$ & 1.33 & Y & 3.83 & 1.24 \\
$10 \%$ & 1.37 & Y & 4.07 & 1.90 \\
$15 \%$ & 1.17 & Y & 4.03 & 1.87 \\
$20 \%$ & 1.23 & Y & 4.03 & 1.87 \\
$25 \%$ & 1.20 & Y & 4.33 & 1.93 \\
$30 \%$ & 1.23 & Y & 4.13 & 1.93 \\
$35 \%$ & 1.27 & Y & 4.30 & 1.90 \\
$40 \%$ & 1.10 & $Y$ & 4.40 & 1.90 \\
$45 \%$ & 0.87 & $Y$ & 4.43 & 1.97 \\
$50 \%$ & 1.13 & $Y$ & 4.63 & 1.97 \\
$55 \%$ & 1.10 & $Y$ & 4.80 & 1.93 \\
$60 \%$ & 1.10 & $Y$ & 4.83 & 1.97 \\
$65 \%$ & 1.03 & Y & 4.90 & 1.97 \\
\hline
\end{tabular}


Figure A-1. Siesta Key, FL size gradation (A), images in dry and moist state (B) and images by size class (C).
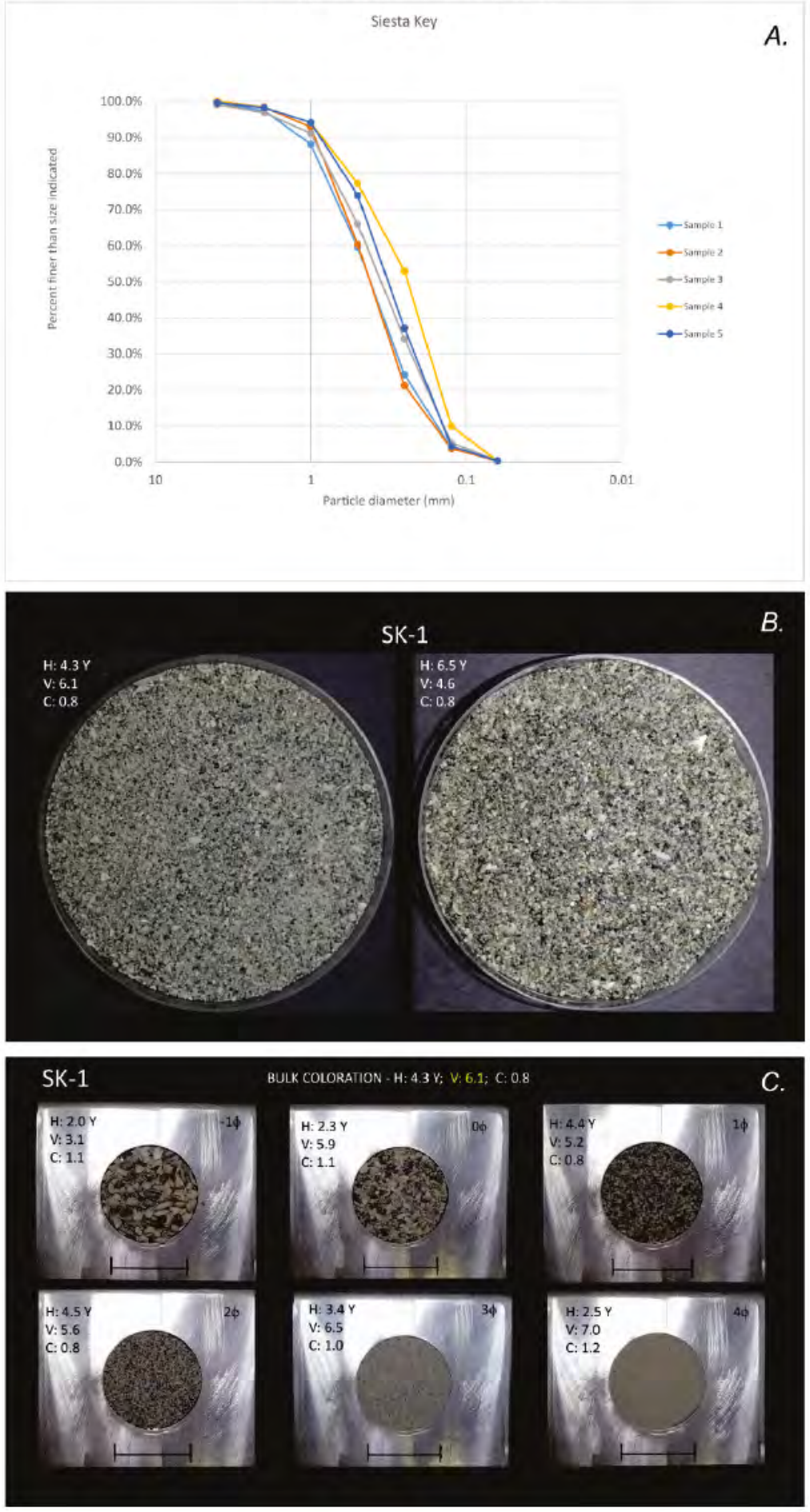
Figure A-2. Galveston, TX size gradation (A), images in dry and moist state $(B)$ and images by size class (C).

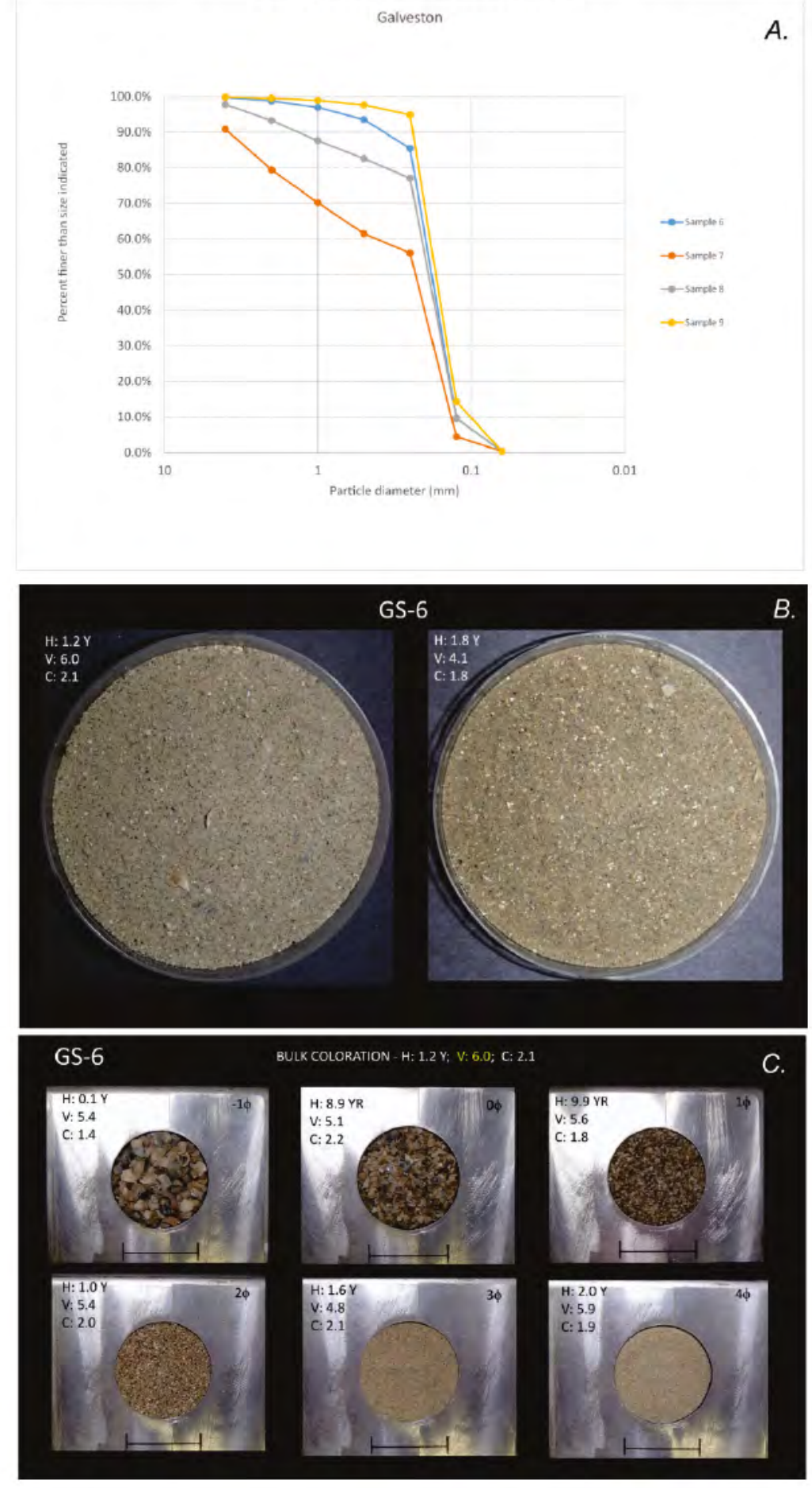


Figure A-3. Egmont Key, FL size gradation (A), images in dry and moist state (B) and images by size class (C).

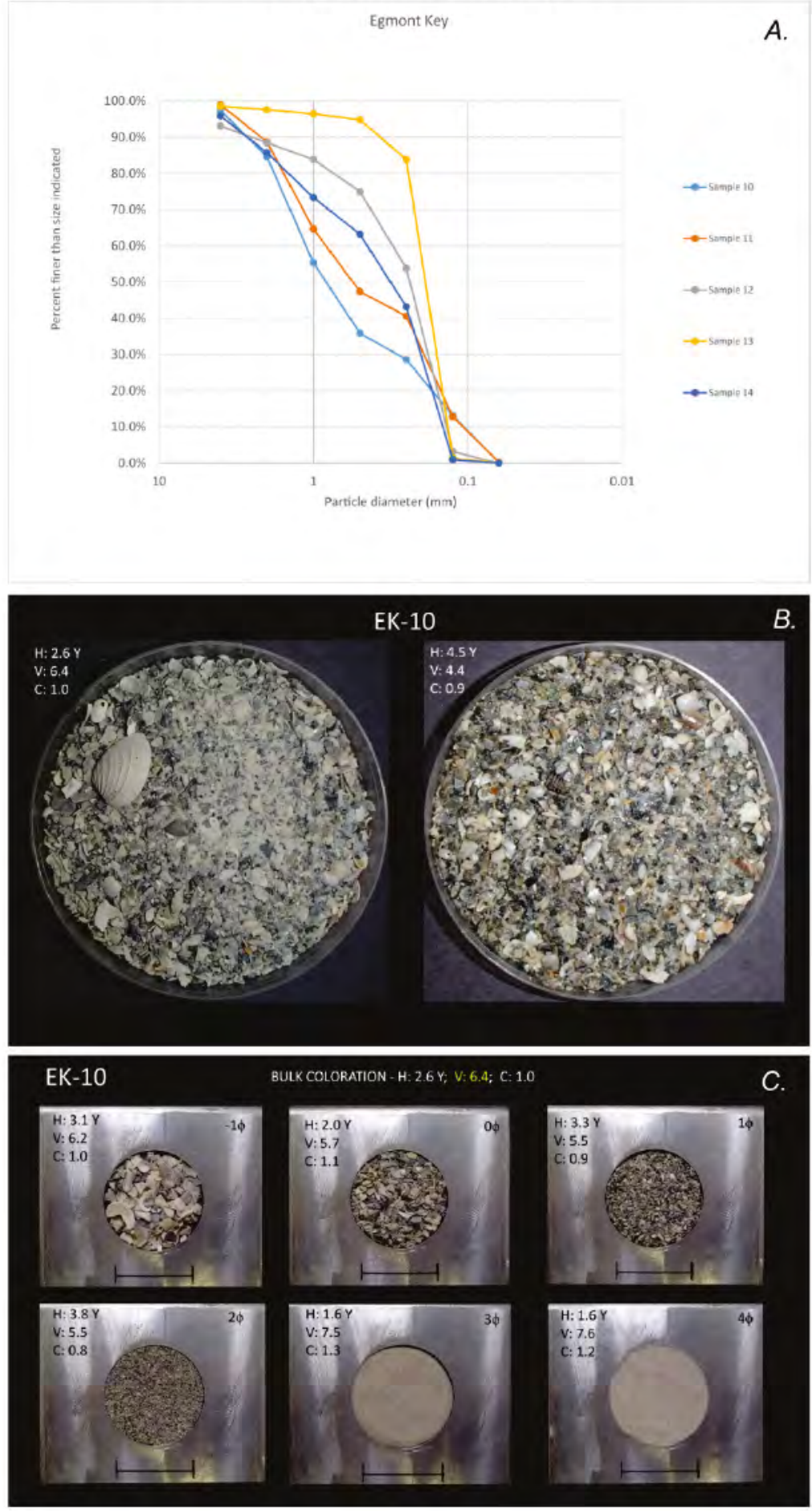


Figure A-4. Ventura Harbor, CA size gradation (A), images in dry and moist state (B) and images by size class (C).

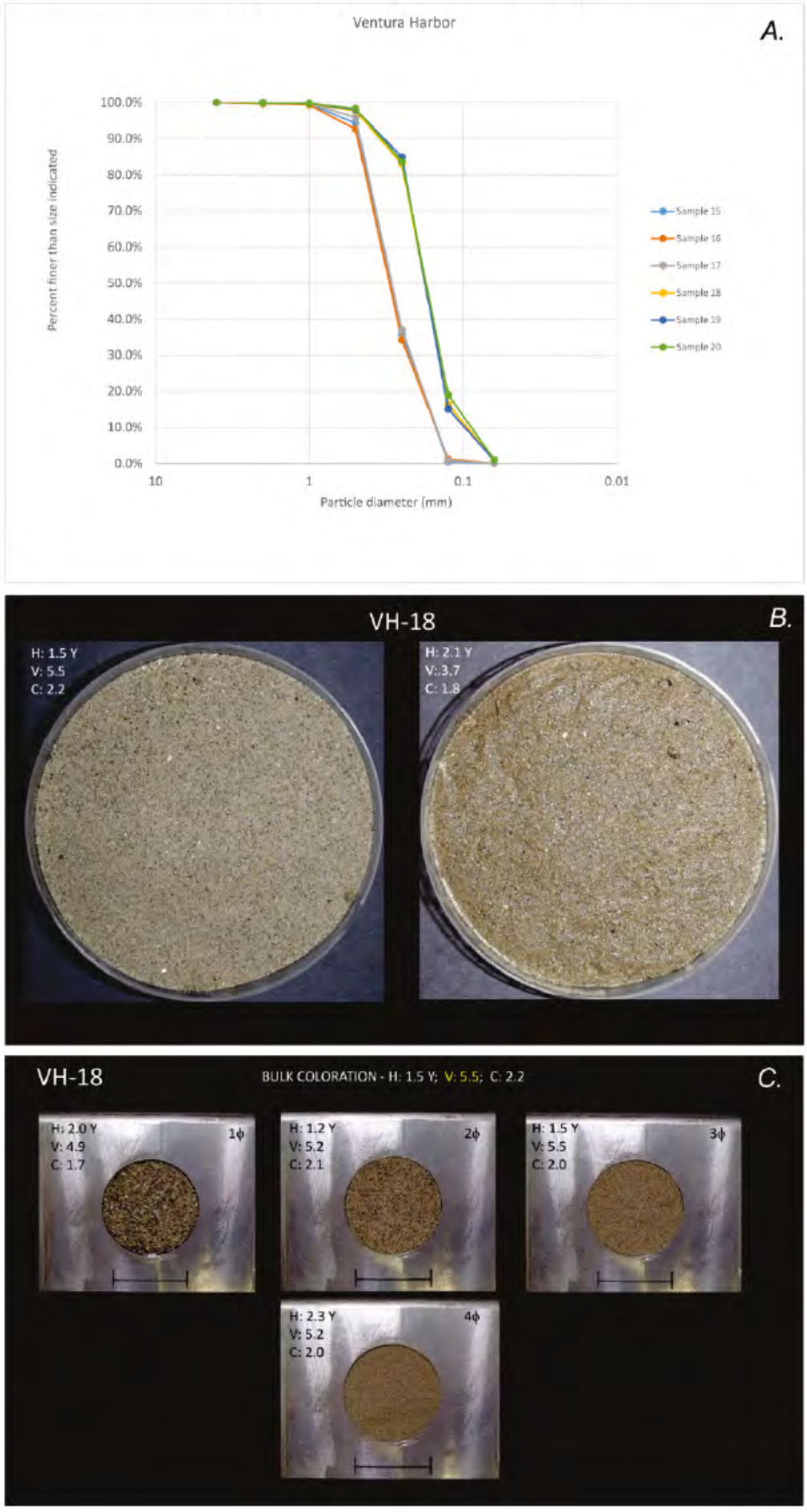


Figure A-5. Miami, FL size gradation (A), images in dry and moist state (B) and images by size class (C).

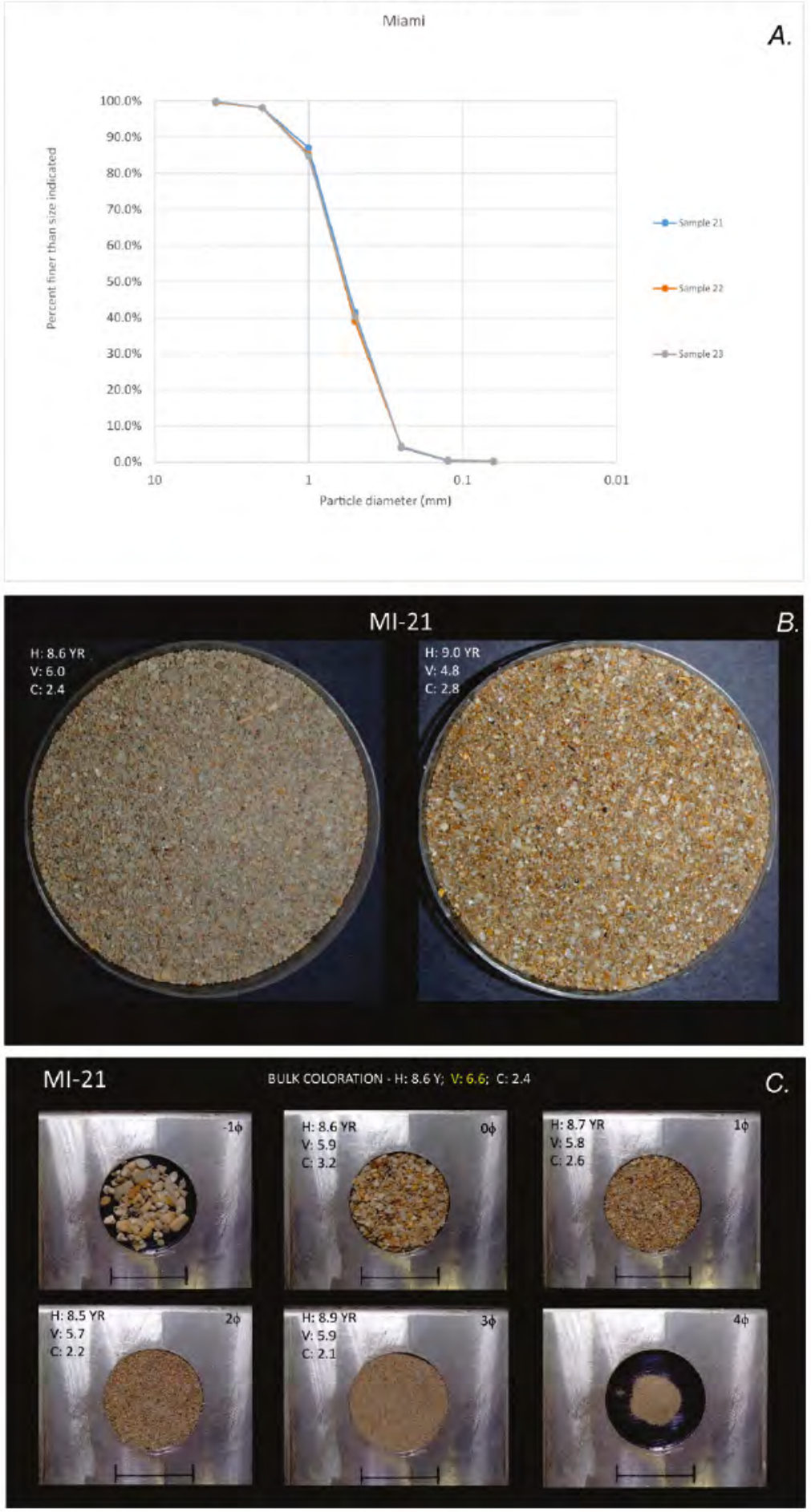


Figure A-6. Huntington Harbor, CA size gradation (A), images in dry and moist state $(B)$ and images by size class (C).

Huntington Harbor

A.

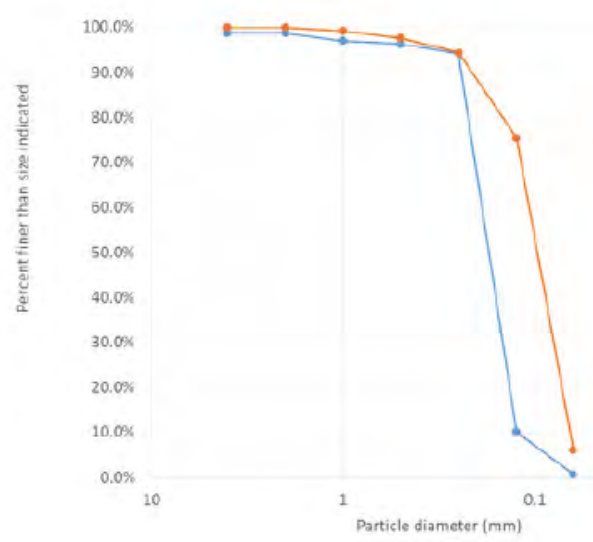

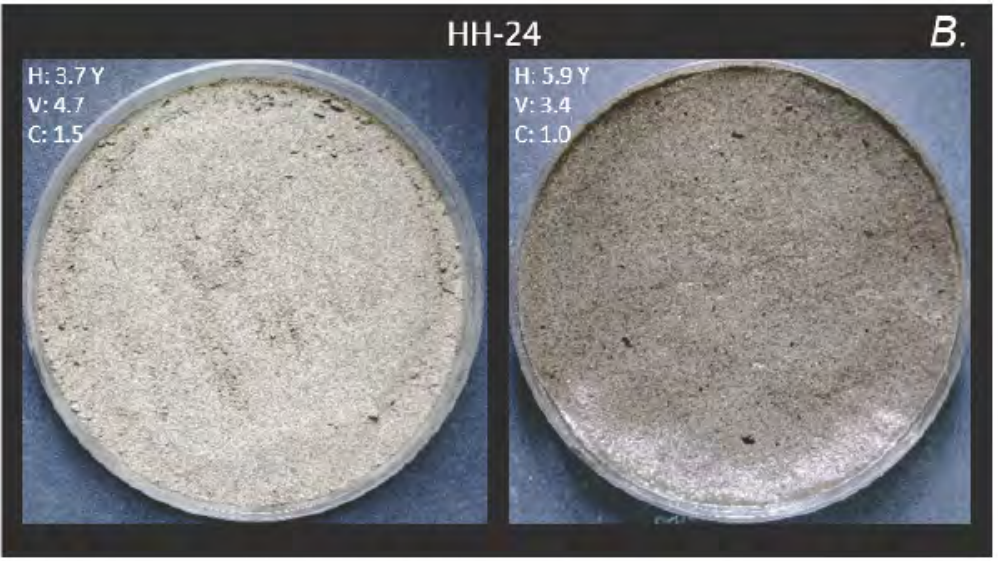

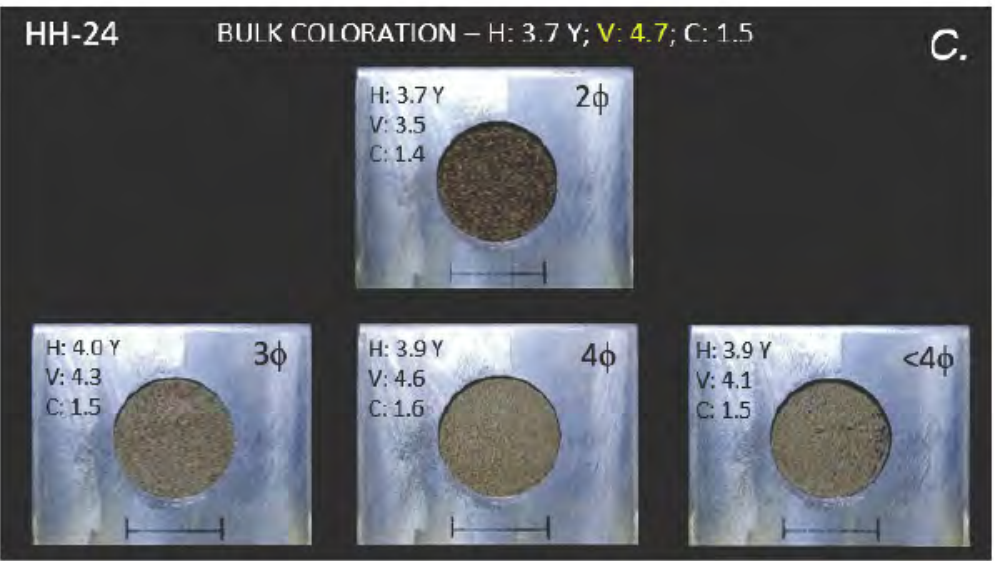


Figure A-7. Philadelphia, PA size gradation (A), images in dry and moist state $(B)$ and images by size class (C).

Philadelphia

A.

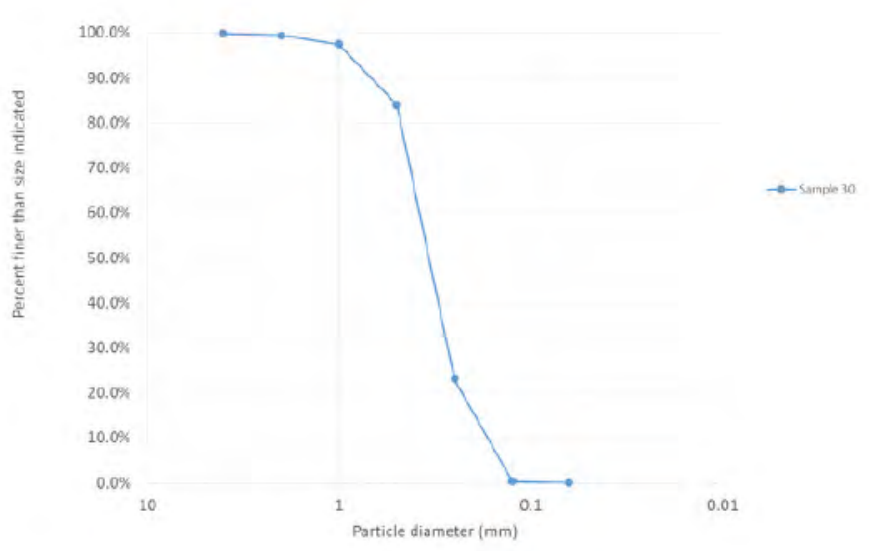

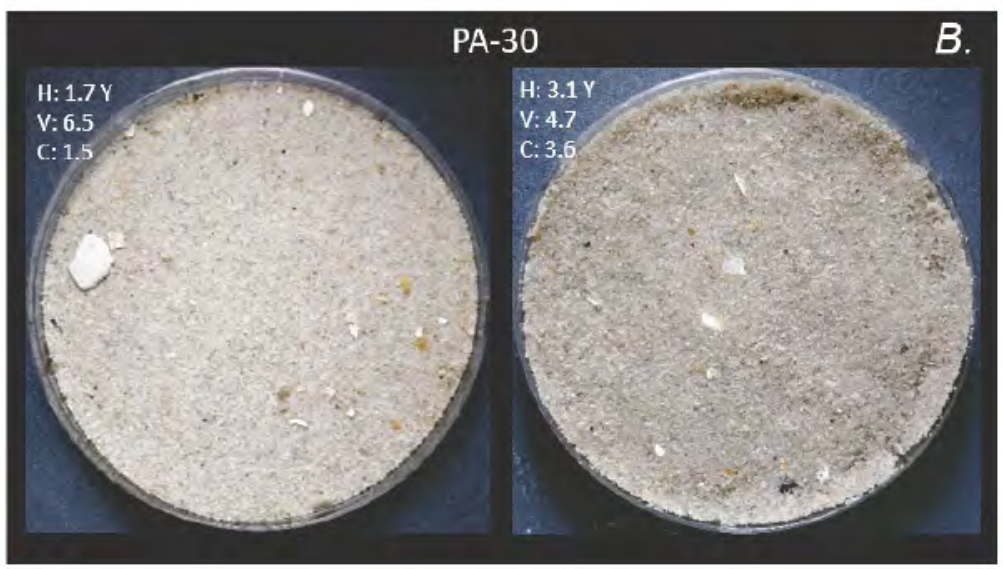
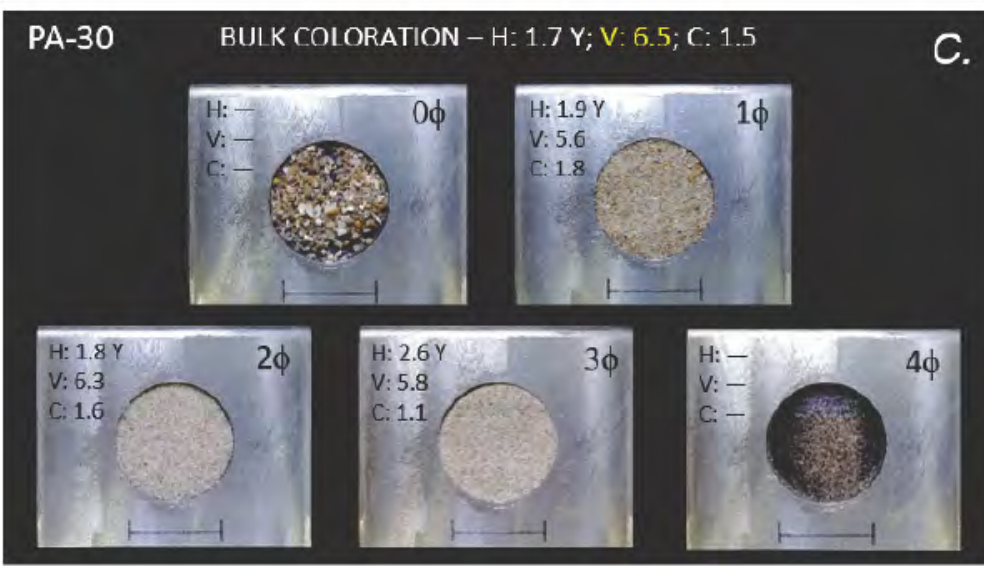
Figure A-8. Jackson, AL size gradation (A), images in dry and moist state $(B)$ and images by size class (C).

Jackson, Alabama

A.

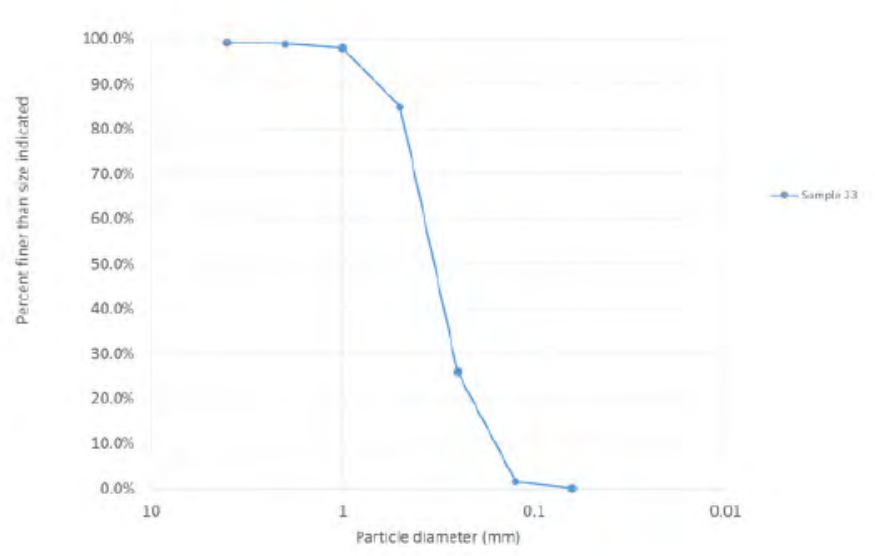

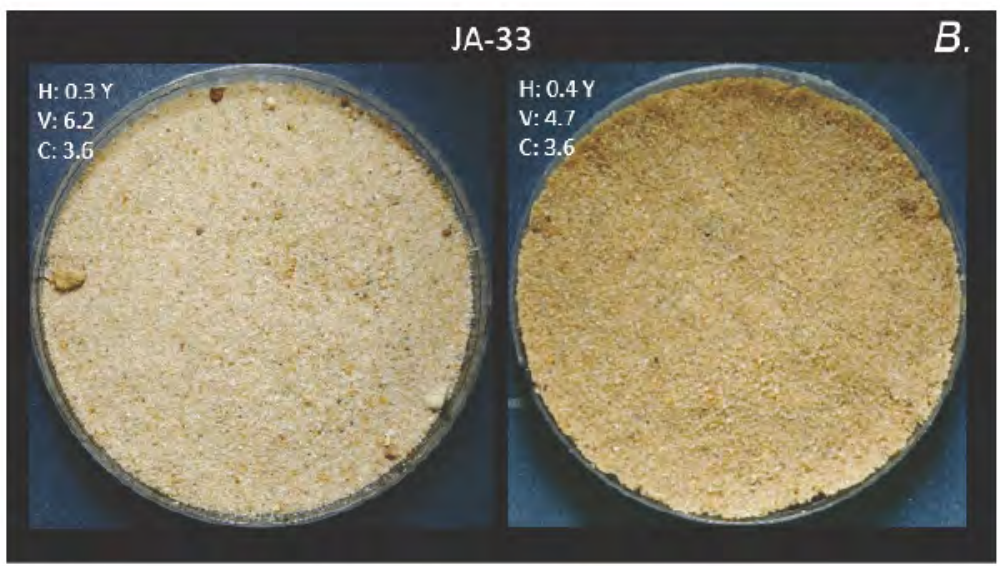
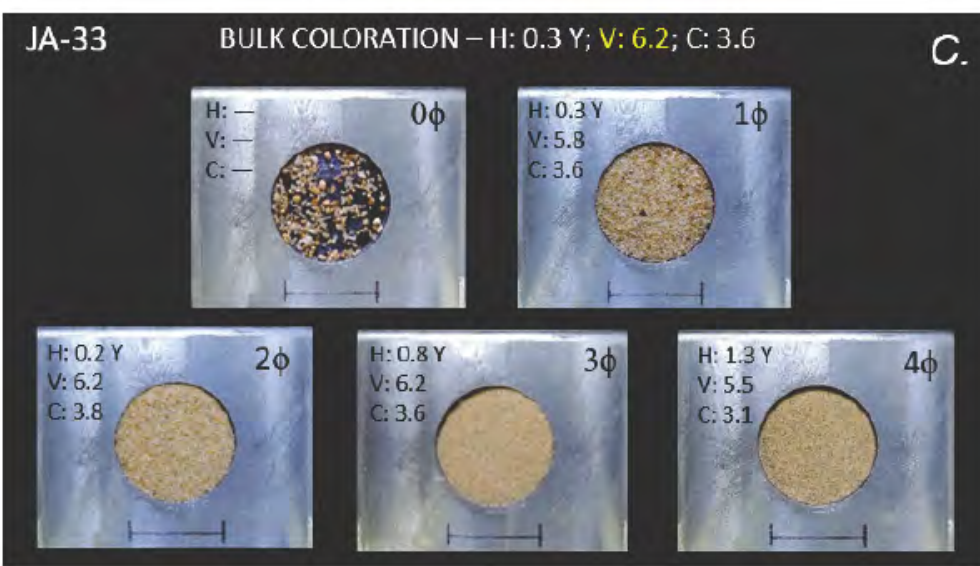
Figure A-9. Ocean City, MD size gradation (A), images in dry and moist state (B) and images by size class (C).

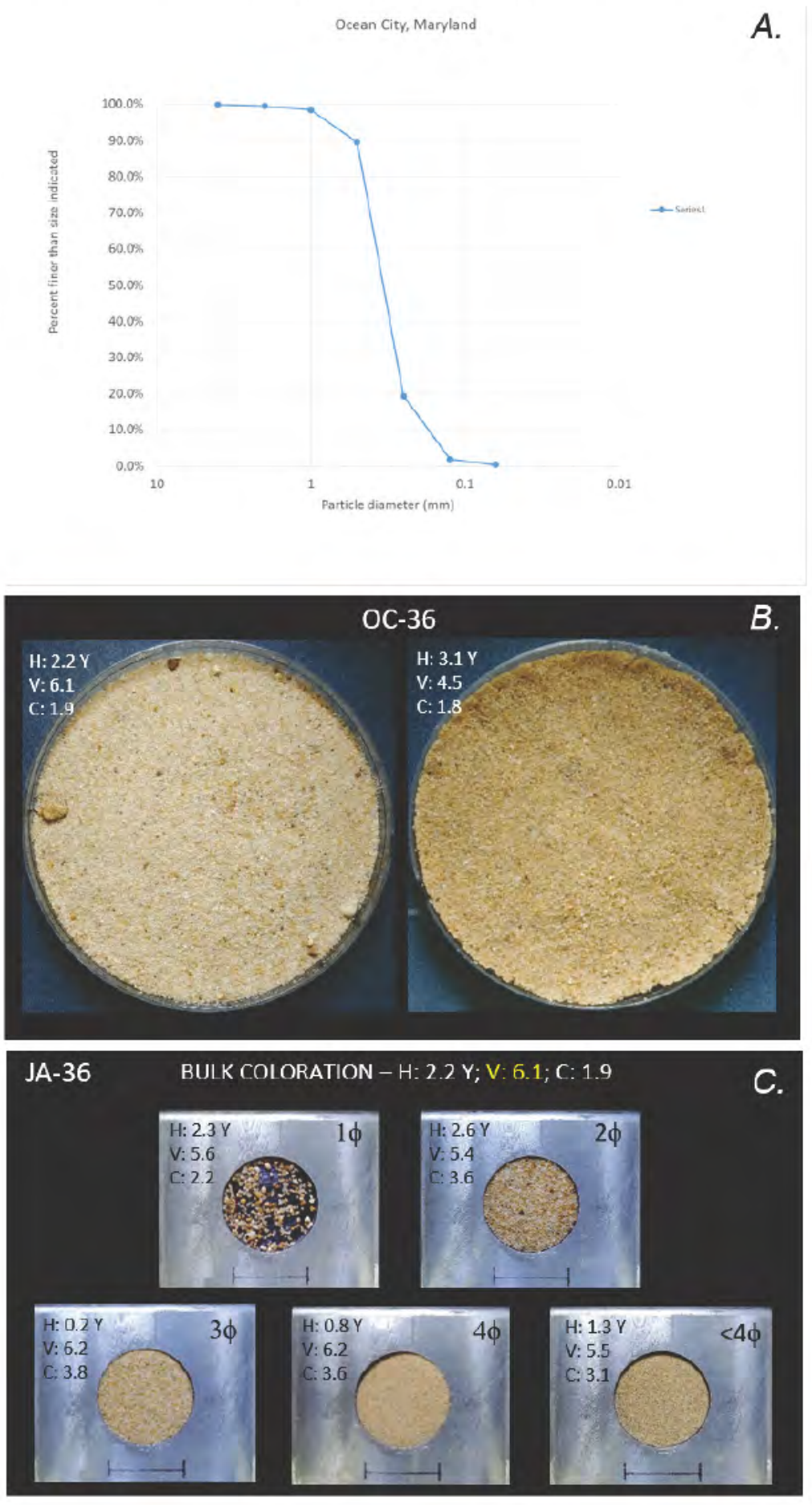




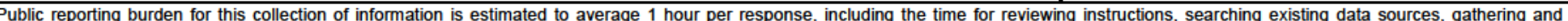

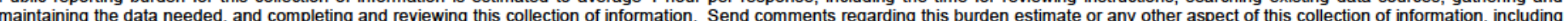

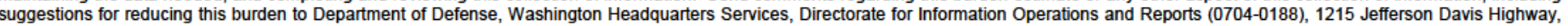

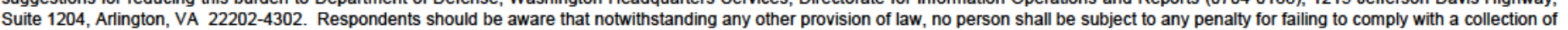
information if it does not display a currently valid OMB control number. PLEASE DO NOT RETURN YOUR FORM TO THE ABOVE ADDRESS.

\begin{tabular}{|l|l|l}
\hline 1. REPORT DATE (DD-MM-YYYY) & 2. REPORT TYPE & 3. DATES COVERED (From - To)
\end{tabular}

December 2020 Final

4. TITLE AND SUBTITLE

5a. CONTRACT NUMBER

Incorporating Color Change Propensity into Dredged Material Management to Increase Beneficial Use Opportunities

5b. GRANT NUMBER

5c. PROGRAM ELEMENT NUMBER

5d. PROJECT NUMBER

5e. TASK NUMBER

5f. WORK UNIT NUMBER

8. PERFORMING ORGANIZATION REPORT NUMBER

ERDC TR-20-29

3909 Halls Ferry Road

Vicksburg, MS 39180

9. SPONSORING / MONITORING AGENCY NAME(S) AND ADDRESS(ES)

U.S. Army Corps of Engineers

Dredging Operations Environmental Research Program

3909 Halls Ferry Road

Vicksburg, MS 39180 NUMBER(S)

\section{DISTRIBUTION / AVAILABILITY STATEMENT}

Approved for public release; distribution is unlimited.

\section{SUPPLEMENTARY NOTES}

\section{ABSTRACT}

Dredged materials provide a number of beneficial use opportunities, including beach nourishment, habitat creation and restoration, and other activities. In situ sediment color is important for determining aesthetic and habitat suitability, for beach nourishment, and for other projects. However, dredged materials must meet locally established color compatibility requirements (for example, material cannot be too dark). Often, potential sediment sources are close to meeting specified color thresholds, and previous observations suggest that sediments lighten over time. In response to these observations, this study quantified sediment color change potential in a dredged material management context. Results indicate that dredged material sediment color responded to changes in secondary color components, sediment mixing, and photolytic bleaching-improving the sediment color for beneficial use application. Findings al-lowed for development of a conceptual color change capacity framework and supported development of tools for resource managers to incorporate color change dynamic into planning and operations activities. The following report provides a framework for determining the color change capacity of dredged materials using (1) a comprehensive laboratory approach and (2) a semiquantitative index based on source material and placement location conditions. These tools allow practitioners to incorporate dredged-material color change into resource management decisions, thus increasing beneficial use opportunities.

\section{SUBJECT TERMS}
Dredging
Dredging spoil - Color
Restoration ecology

Dredging spoil - Management

Beach nourishment

16. SECURITY CLASSIFICATION OF:

\begin{tabular}{l|r|}
\hline $\begin{array}{l}\text { a. REPORT } \\
\text { Unclassified }\end{array}$ & $\begin{array}{r}\text { b. ABSTRACT } \\
\text { Unclassified }\end{array}$ \\
\hline
\end{tabular}

c. THIS PAGE

Unclassified

\begin{tabular}{|c|c|} 
17. LIMITATION & $\begin{array}{c}\text { 18. NUMBER } \\
\text { OF ABSTRACT }\end{array}$ \\
OF PAGES \\
\cline { 3 - 3 }
\end{tabular}

19a. NAME OF RESPONSIBLE PERSON

19b. TELEPHONE NUMBER (include area code) 
